\title{
ZOOLOGICAL EXPLORATION OF THE CONTINENTAL SHELF OF SURINAM: \\ THE FORAMINIFERA OF THE SHELF OF SURINAM AND THE GUYANAS
}

\author{
by \\ J. HOFKER \\ Scheveningselaan 157, 2554 EW The Hague, The Netherlands \\ With 8 text-figures and 17 plates
}

INDEX

Introduction

List of samples studied for Foraminifera

p. 5

Alphabetic list of species found in the sam

p. 7

Notes on the distribution of some species

p. 10

Systematic part

p. 16

Genus Reophax Montfort, 1808

p. 19

Reophax bilocularis Flint

Reophax compressus Goës

p. 19

Reophax hispidulis Cushman

p. 19

Reophax regularis Höglund

p. 20

Reophax guttifer Brady

p. 20

Reophax curtus Cushman

p. 20

p. 21

p. 21

Ammobaculites agglutinans d'Orbigny .......................................................... p. 22

Ammobaculites americanus Cushman ........................................................... p. 22

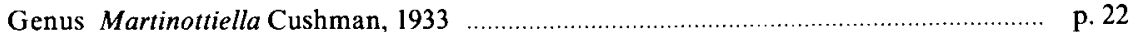

Martinottiella pallida (Cushman) …................................................................. p. 23

Genus Liebusella Cushman, 1933 ...................................................................... p. 23

Liebusella arenosa nov. spec. .................................................................... p. 24

Liebusella eleganta nov. spec. ................................................................................. p. 25

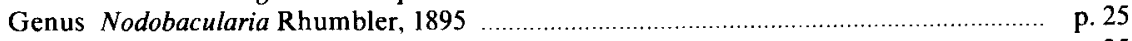

Nodobacularia pustulosa nov. spec. ……........................................................... p. 25

Genus Sigmopyrgo nov. gen. ............................................................................ p. 26

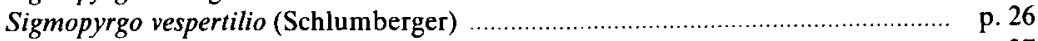

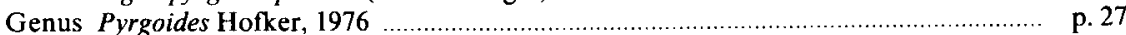

Pyrgoides nasutus (Cushman) ……..................................................................... p. 27

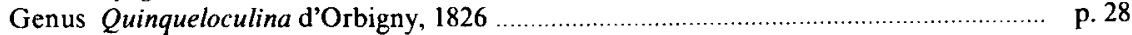

Quinqueloculina polygona d'Orbigny ............................................................. p. 28

Quinqueloculina horrida Cushman ........................................................ p. 28

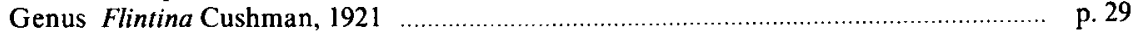

Flintina bradyana Cushman ......................................................................... p. 29

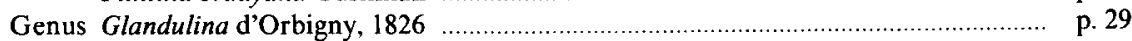


ZOOLOGISCHE VERHANDELINGEN 201 (1983)

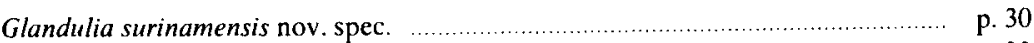

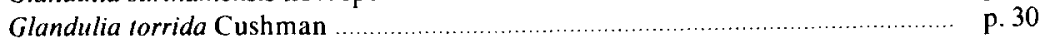

Genus Dentalina Risso, 1826 ..................................................................... p. 31

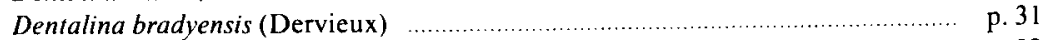

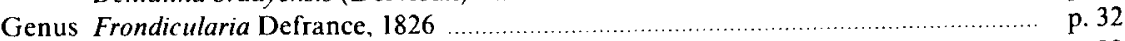

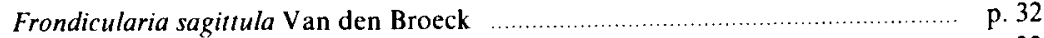

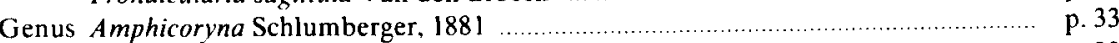

Amphicoryna rugosa (d'Orbigny) …........................................................... p. 33

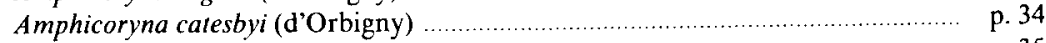

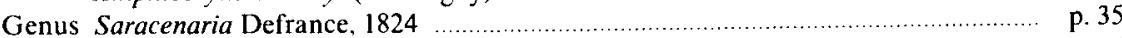

Saracenaria palmerae Cushman \& Todd .......................................................... p. 35

Saracenaria arcuata d'Orbigny .................................................................. p. 35

Saracenaria eleganta nov. spec. …............................................................. p. 36

Saracenaria ampla Cushman \& Todd …..................................................... p. 36

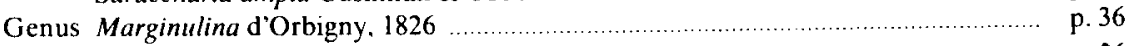

Marginulina tenuis Bornemann …........................................................ p. 36

Marginulina glabrata (Cushman) ….......................................................... p. 37

Marginulina planata Phleger \& Parker …................................................... p. 38

Marginulina anderseni nov. spec. ............................................................ p. 38

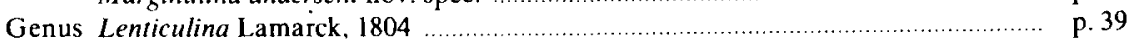

Lenticulina calcar (Linnaeus) ..................................................................... p. 39

Lenticulina antillea (Cushman) ……............................................................. p. 39

Lenticulina formosa (Cushman) …............................................................. p. 47

Lenticulina iota (Cushman) …................................................................. p. 47

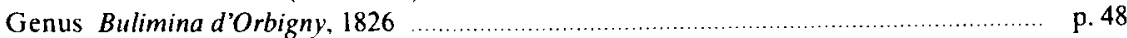

Bulimina marginata d'Orbigny …................................................................. p. 48

Bulimina spicata Phleger \& Parker ............................................................. p. 49

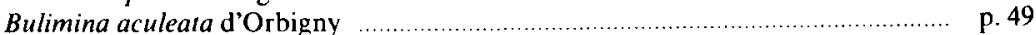

Bulimina alazanensis Cushman …................................................................ p. 50

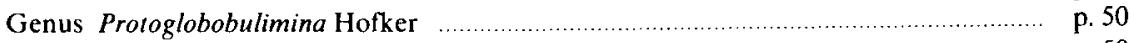

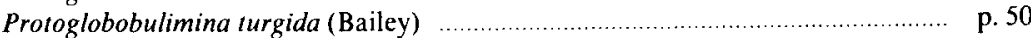

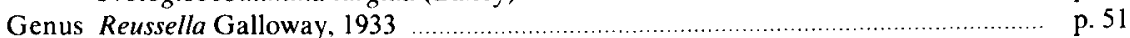

Reussella atlantica Cushman ….................................................................. p. 51

Reussella mortenseni Hofker ................................................................... p. 52

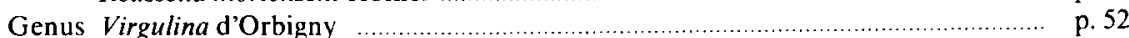

Virgulina pontoni Cushman …...................................................................... p. 52

Virgulina compressa (Bailey) _................................................................ p. 53

Virgulina mexicana Cushman …................................................................... p. 53

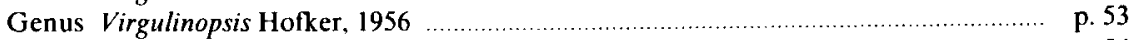

Virgulinopsis cubana (Bermúdez) ……........................................................ p. 54

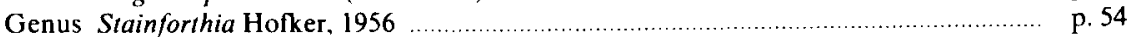

Stainforthia exilis (Brady) ............................................................................ p. 54

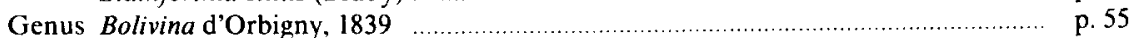

Bolivina mexicana Cushman …................................................................... p. 55

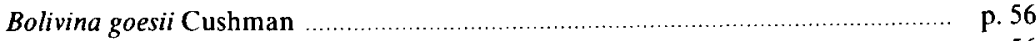

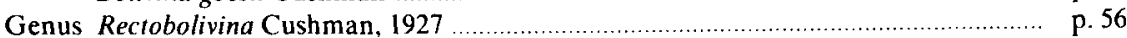

Rectobolivina advena (Cushman) …............................................................ p. 56

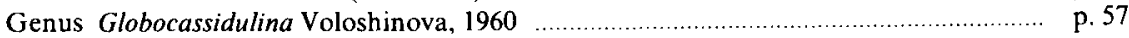

Globocassidulina aperta nov. spec. ............................................................... p. 57

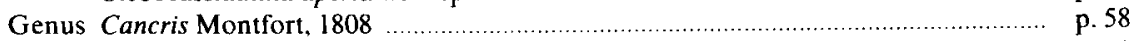

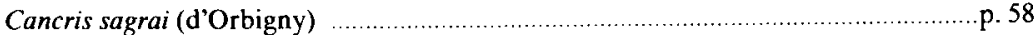

Genus Hanzawaia Asano, 1944 ........................................................................ p. 58

Hanzawaia concentrica (Cushman) ….......................................................... p. 59

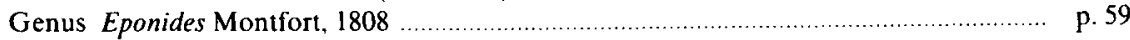




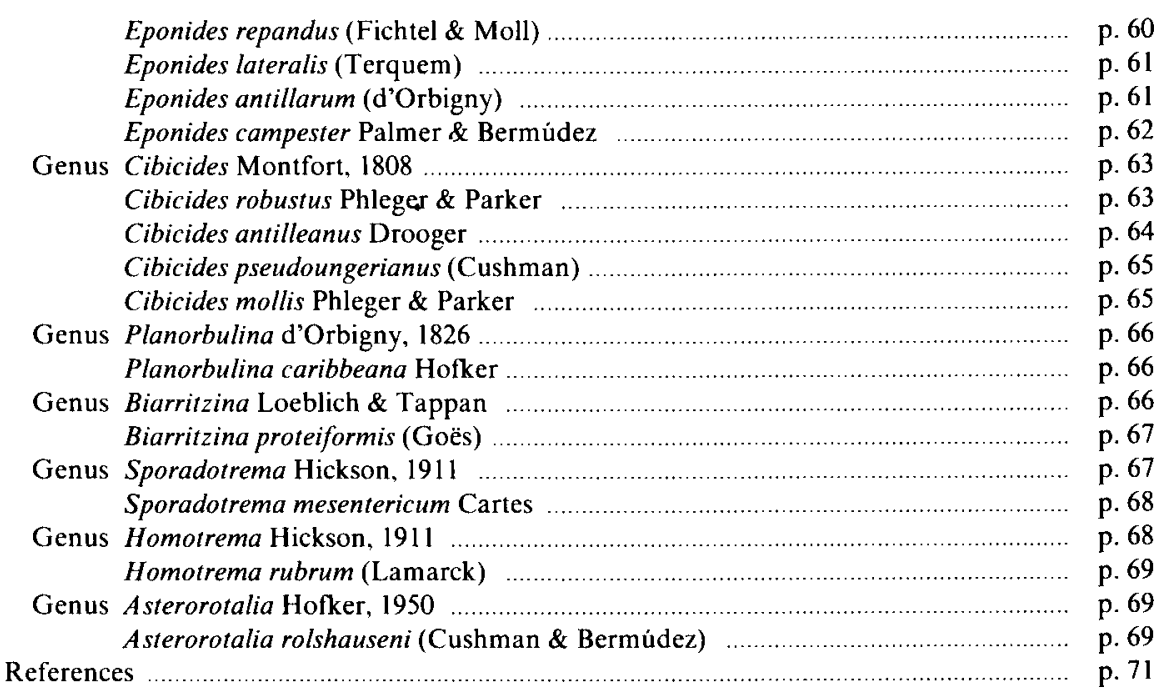

\section{INTRODUCTION}

The present study deals with the Foraminifera collected during two expeditions on board of the hydrographic vessels H. N1. M.S. "Snellius" (1966) and H. N1. M.S. "Luymes" (1969) on the continental shelf of Surinam (O.C.P.S. I and II; see Hydrographer of the Royal Netherlands Navy, 1967; 1971), and during the "Luymes" Guyana Shelf Expedition (1970; CICAR cruise 15).

The area of sampling lies between the mouths of the rivers Oyapock and Mazarani, and roughly covers the shelf and slope between $6^{\circ} 8^{\prime} \mathrm{N}$ Lat and $53^{\circ} 58^{\prime} \mathrm{W}$ Long (fig. 1). All the samples from the Guyana shelf containing Foraminifera were taken with the Van Veen-grab. No Van Veen-grab sampling was done during the Guyana shelf expedition. The only samples of Foraminifera collected during this expedition were obtained with the Agassiztrawl. As a result these samples consist of larger specimens only, which are not representative of the foraminiferal faunae on the spot.

Unfortunately, the rough samples from the Surinam shelf were not wellpreserved (stored in plastic bags with alcohol added), so that in some cases it proved to be impossible to decide with certainty whether recent or sub-fossil material was involved.

Altogether 122 stations were sampled during the O.C.P.S. expeditions (referred to in the text as sta. 1-122), against 123 during the Guyana shelf expedition (sta. G1-G123). Stations which did not yield Foraminifera are not considered and have been omitted from fig. 1.

As appears from the map, the shelf proper ends at a depth of about $80 \mathrm{~m}$, at 


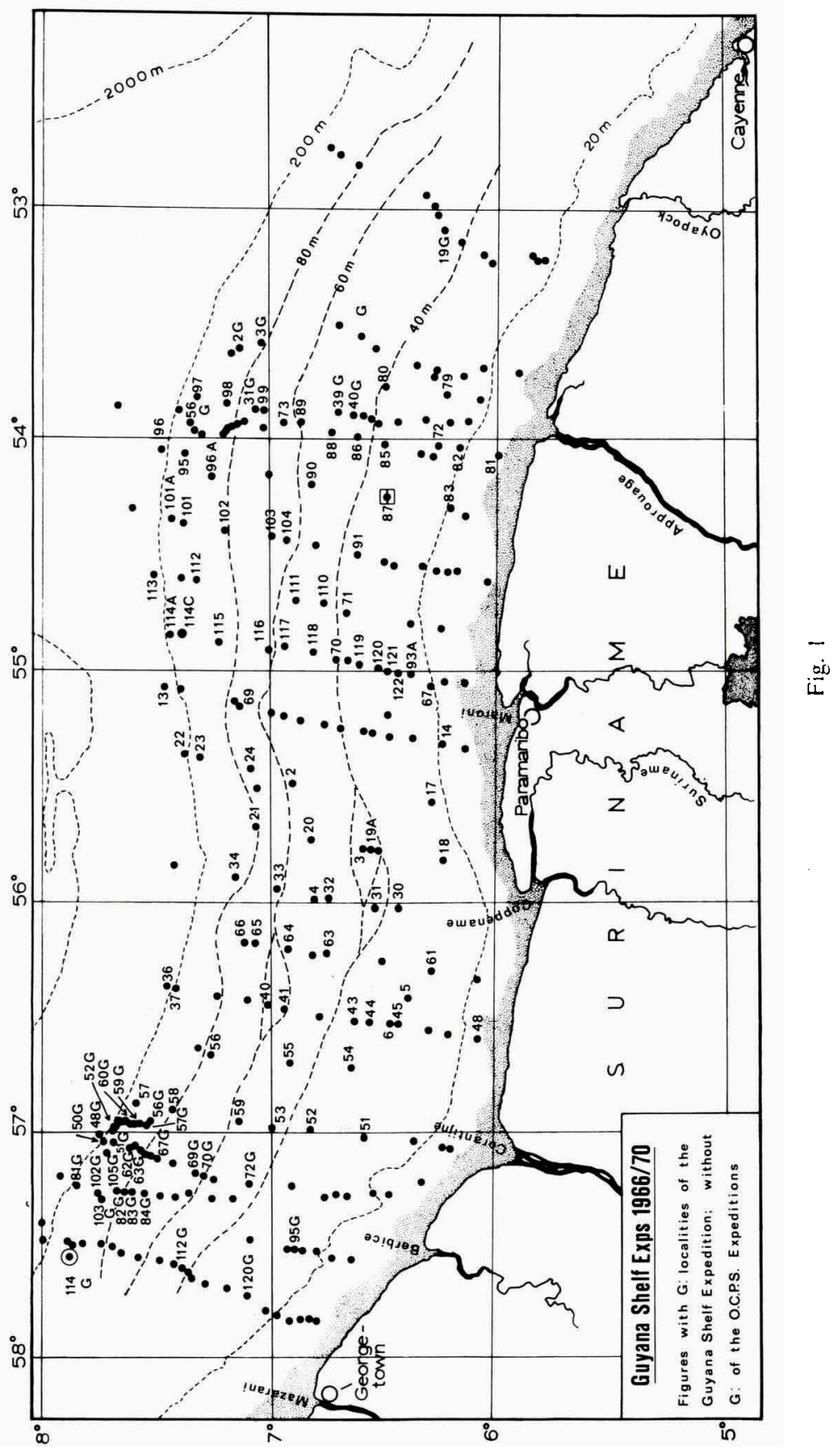


some $100 \mathrm{~km}$ from the mainland, and is followed by a rather steep slope. In spite of the fact that the area is close to the equator, the foraminiferal shelf fauna as a whole does not appear to be very tropical. The water temperature on the bottom of the shelf is relatively low. Eisma \& Van Bennekom (1971: 28, fig. 36) showed that this is partly caused by upwelling of cold water over the slope. In addition, as the prevailing current along the coast is in northwestern direction, the water on the shelf is mixed with Amazone water, causing turbidity in this area, so that absorption of light and heat mainly occurs in the upper water layers. Secchi disc investigations (Eisma \& Van Bennekom, 1971: 27, figs. 25, 32-34) proved this poor light penetration: Secchi disc visibility on the shelf is nowhere more than $20 \mathrm{~m}$, and often less. These environmental conditions result in a strong selection in Foraminifera, as will be discussed later on.

I wish to thank Mr. J.C. den Hartog and Mr. M. Slierings, both of the Rijksmuseum van Natuurlijke Historie, for their help in providing the material for this study; Mr. Den Hartog also for reading and commenting on the manuscript.

\section{SAMPLES STUdied FOR ForAminifERA}

Foraminifera are sensitive to temperature (see Hofker, 1970b: 92; 1978: 16 ff; 1980: 22-29). As the temperature decreases with increasing depth, the samples studied are arranged here according to depth. Rich samples (with more than 15 species) are marked with an asterisk.

Station no.

$\begin{array}{crl}114 \mathrm{G} & 6 \mathrm{~m} & 07^{\circ} 49^{\prime} \mathrm{N} 57^{\circ} 50^{\prime} \mathrm{W} \text { soft mud } \\ 81 & 8 \mathrm{~m} & 05^{\circ} 59.4^{\prime} \mathrm{N} 54^{\circ} 04.4^{\prime} \mathrm{W} \text { blue mud } \\ 48 & 12 \mathrm{~m} & 06^{\circ} 05.3^{\prime} \mathrm{N} 56^{\circ} 36.6^{\prime} \mathrm{W} \text { soft mud } \\ 14 & 18 \mathrm{~m} & 06^{\circ} 14.2^{\prime} \mathrm{N} 55^{\circ} 19.2^{\prime} \mathrm{W} \text { heavy clay } \\ 83 & 19.5 \mathrm{~m} & 06^{\circ} 11.8^{\prime} \mathrm{N} 54^{\circ} 17.9^{\prime} \mathrm{W} \text { soft clay } \\ 67 & 20.5 \mathrm{~m} & 06^{\circ} 17^{\prime} \mathrm{N} 55^{\circ} 04^{\prime} \mathrm{W} \text { grey mud } \\ 82 & 22.2 \mathrm{~m} & 06^{\circ} 09^{\prime} 4^{\prime} \mathrm{N} 54^{\circ} 02.8^{\prime} \mathrm{W} \text { reef fragments } \\ 120 \mathrm{G} & 24 \mathrm{~m} & 07^{\circ} 06^{\prime} \mathrm{N} 57^{\circ} 43^{\prime} \mathrm{W} \text { muddy sand, shells } \\ 85 \mathrm{G} & 24 \mathrm{~m} & 06^{\circ} 54^{\prime} \mathrm{N} 57^{\circ} 30^{\prime} \mathrm{W} \text { mixed hard bottom } \\ 72 & 24 \mathrm{~m} & 06^{\circ} 15^{\prime} \mathrm{N} 54^{\circ} 02^{\prime} \mathrm{W} \text { sandy mud } \\ 79 & 27 \mathrm{~m} & 06^{\circ} 13.3^{\prime} \mathrm{N} 53^{\circ} 49.5^{\prime} \mathrm{W} \text { coarse sand } \\ 45 & 27 \mathrm{~m} & 06^{\circ} 18.7^{\prime} \mathrm{N} 56^{\circ} 34.2^{\prime} \mathrm{W} \text { coarse sand } \\ 51 & 29 \mathrm{~m} & 06^{\circ} 36.1^{\prime} \mathrm{N} 57^{\circ} 02^{\prime} \mathrm{W} \text { coarse sand } \\ 18 & 30 \mathrm{~m} & 06^{\circ} 13.3^{\prime} \mathrm{N} 55^{\circ} 50^{\prime} \mathrm{W} \text { sand } \\ 72 \mathrm{G} & 31 \mathrm{~m} & \mathrm{et}^{\circ} 05^{\prime} \mathrm{N} 57^{\circ} 14^{\prime} \mathrm{W} \text { sand, shells } \\ 17 & 31 \mathrm{~m} & 06^{\circ} 17.5^{\prime} \mathrm{N} 55^{\circ} 33.8^{\prime} \mathrm{W} \text { sandy clay } \\ 121 & 32.5 \mathrm{~m} & 06^{\circ} 28^{\prime} \mathrm{N} 55^{\circ} 00^{\prime} \mathrm{W} \text { coarse sand } \\ 87 & 33.5 \mathrm{~m} & 06^{\circ} 26.1^{\prime} \mathrm{N} 54^{\circ} 15.3^{\prime} \mathrm{W} \text { fine sand, glauconite } \\ 45 & 34 \mathrm{~m} & 06^{\circ} 26.5^{\prime} \mathrm{N} 56^{\circ} 32.8^{\prime} \mathrm{W} \text { sandy mud }\end{array}$




\begin{tabular}{|c|c|c|}
\hline 67 & $34 \mathrm{~m}$ & $06^{\circ} 26^{\prime} \mathrm{N} 55^{\circ} 12^{\prime} \mathrm{W}$ mud \\
\hline 80 & $34.5 \mathrm{~m}$ & $06^{\circ} 28.8^{\prime} \mathrm{N} 53^{\circ} 46.9^{\prime} \mathrm{W}$ coarse sand \\
\hline 61 & $35 \mathrm{~m}$ & $06^{\circ} 17.1^{\prime} \mathrm{N} 56^{\circ} 18.8^{\prime} \mathrm{W}$ clay with sand ${ }^{*}$ \\
\hline 3 & $36 \mathrm{~m}$ & $06^{\circ} 31.5^{\prime} \mathrm{N} 55^{\circ} 47.3^{\prime} \mathrm{W}$ sandy clay* \\
\hline 85 & $36 \mathrm{~m}$ & $06^{\circ} 28.7^{\prime} \mathrm{N} 54^{\circ} 02.2^{\prime} \mathrm{W}$ sandy mud \\
\hline 120 & $36.5 \mathrm{~m}$ & $06^{\circ} 30.3^{\prime} \mathrm{N} 54^{\circ} 59^{\prime} \mathrm{W}$ sandy mud \\
\hline 43 & $37 \mathrm{~m}$ & $06^{\circ} 37.2^{\prime}{\mathrm{N} 56^{\circ} 32.8^{\prime} \mathrm{W} \text { sand }}^{*}$ \\
\hline 91 & $37.3 \mathrm{~m}$ & $06^{\circ} 35.8^{\prime} \mathrm{N} 54^{\circ} 30^{\prime} \mathrm{W}$ sandy mud \\
\hline 71 & $37.5 \mathrm{~m}$ & $06^{\circ} 37.9^{\prime} \mathrm{N} 54^{\circ} 44.7^{\prime} \mathrm{W}$ sandy mud \\
\hline $19 \mathrm{~A}$ & $38 \mathrm{~m}$ & $06^{\circ} 35^{\prime} \mathrm{N}^{\circ} 55^{\circ} 55.3^{\prime} \mathrm{W}$ sand* \\
\hline 31 & $38 \mathrm{~m}$ & $06^{\circ} 32.2^{\prime} \mathrm{N} 56^{\circ} 02.1^{\prime} \mathrm{W}$ sandy clay* \\
\hline 44 & $38 \mathrm{~m}$ & $06^{\circ} 33.6^{\prime} \mathrm{N} 56^{\circ} 31.6^{\prime} \mathrm{W}$ sandy mud* \\
\hline 53 & $38 \mathrm{~m}$ & $07^{\circ} 05^{\prime} \mathrm{N} 56^{\circ} 58.2^{\prime} \mathrm{W}$ coarse sand \\
\hline 54 & $38 \mathrm{~m}$ & $06^{\circ} 38.8^{\prime} \mathrm{N} 56^{\circ} 43.8^{\prime} \mathrm{W} \mathrm{mud}^{*}$ \\
\hline $112 \mathrm{G}$ & $39 \mathrm{~m}$ & $07^{\circ} 24^{\prime} \mathrm{N} 57^{\circ} 36^{\prime} \mathrm{W}$ muddy sand \\
\hline 52 & $39 \mathrm{~m}$ & $06^{\circ} 50.3^{\prime} \mathrm{N} 56^{\circ} 59.2^{\prime} \mathrm{W}$ coarse sand ${ }^{*}$ \\
\hline 70 & $40 \mathrm{~m}$ & $06^{\circ} 39^{\prime} \mathrm{N} 54^{\circ} 57^{\prime} \mathrm{W}$ fine sand \\
\hline 30 & $41 \mathrm{~m}$ & $06^{\circ} 26.2^{\prime} \mathrm{N} 56^{\circ} 02.5^{\prime} \mathrm{W}$ heavy clay* \\
\hline $70 \mathrm{G}$ & $41 \mathrm{~m}$ & $07^{\circ} 18^{\prime} \mathrm{N} 57^{\circ} 12^{\prime} \mathrm{W}$ sand. shells \\
\hline 119 & $41.5 \mathrm{~m}$ & $06^{\circ} 36^{\prime} \mathrm{N} 55^{\circ} 58^{\prime} \mathrm{W}$ sandy mud \\
\hline 86 & $42 \mathrm{~m}$ & $06^{\circ} 36^{\prime} \mathrm{N} 54^{\circ} 00 . I^{\prime} \mathrm{W}$ sandy mud* \\
\hline $19 \mathrm{G}$ & $42 \mathrm{~m}$ & $06^{\circ} 15^{\prime} \mathrm{N} 55^{\circ} 06^{\prime} \mathrm{W}$ muddy calcareous sand \\
\hline $40 \mathrm{G}$ & $43 \mathrm{~m}$ & $06^{\circ} 37^{\prime} \mathrm{N} 53^{\circ} 53^{\prime} \mathrm{W}$ muddy sand \\
\hline 83 & $43 \mathrm{~m}$ & $06^{\circ} 44.5^{\prime} \mathrm{N} 56^{\circ} 13.4^{\prime} \mathrm{W}$ sand \\
\hline 5 & $44 \mathrm{~m}$ & $06^{\circ} 49.3^{\prime} \mathrm{N} 56^{\circ} 13.5^{\prime} \mathrm{W}$ sandy clay \\
\hline $5 \mathrm{G}$ & $44 \mathrm{~m}$ & $06^{\circ} 35^{\prime} \mathrm{N} 55^{\circ} 33^{\prime} \mathrm{W}$ calcareous sand \\
\hline 55 & $45 \mathrm{~m}$ & $06^{\circ} 45.7^{\prime} \mathrm{N} 56^{\circ} 42.2^{\prime} \mathrm{W}$ sandy mud ${ }^{*}$ \\
\hline 90 & $45 \mathrm{~m}$ & $06^{\circ} 48^{\prime} \mathrm{N} 54^{\circ} 11.4^{\prime} \mathrm{W}$ sandy mud ${ }^{*}$ \\
\hline $39 \mathrm{G}$ & $45 \mathrm{~m}$ & $06^{\circ} 43^{\prime} \mathrm{N} 53^{\circ} 52^{\prime} \mathrm{W}$ muddy sand \\
\hline $10 \mathrm{G}$ & $45 \mathrm{~m}$ & $06^{\circ} 37^{\prime} \mathrm{N} 53^{\circ} 53^{\prime} \mathrm{W}$ muddy sand \\
\hline $69 \mathrm{G}$ & $46 \mathrm{~m}$ & $07^{\circ} 20^{\prime} \mathrm{N} 57^{\circ} 10^{\prime} \mathrm{W}$ muddy sand \\
\hline 88 & $46 \mathrm{~m}$ & $06^{\circ} 42.8^{\prime} \mathrm{N} 53^{\circ} 48.5^{\prime} \mathrm{W}$ muddy sand \\
\hline 110 & $46.5 \mathrm{~m}$ & $06^{\circ} 45.2^{\prime} \mathrm{N} 54^{\circ} 42.7^{\prime} \mathrm{W}$ muddy sand \\
\hline 20 & $46.5 \mathrm{~m}$ & $06^{\circ} 46.8^{\prime} \mathrm{N} 55^{\circ} 53.7^{\prime} \mathrm{W}$ mud \\
\hline 118 & $48.5 \mathrm{~m}$ & $06^{\circ} 48^{\prime} \mathrm{N} 54^{\circ} 55^{\prime} \mathrm{W}$ sandy mud, shells \\
\hline 4 & $48.5 \mathrm{~m}$ & $06^{\circ} 48.5^{\prime} \mathrm{N} 55^{\circ} 58.9^{\prime} \mathrm{W}$ sandy clay \\
\hline 32 & $48.5 \mathrm{~m}$ & 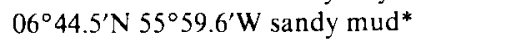 \\
\hline 59 & $49 \mathrm{~m}$ & $07^{\circ} 08.5^{\prime} \mathrm{N} 56^{\circ} 57^{\prime} \mathrm{W}$ coarse sand \\
\hline 2 & $51 \mathrm{~m}$ & $06^{\circ} 44.5^{\prime} \mathrm{N} 55^{\circ} 29^{\prime} \mathrm{W}$ hard sand ${ }^{*}$ \\
\hline 89 & $51.5 \mathrm{~m}$ & $06^{\circ} 50.7^{\prime} \mathrm{N} 53^{\circ} 55.2^{\prime} \mathrm{W}$ muddy sand \\
\hline 111 & $51.5 \mathrm{~m}$ & $06^{\circ} 52^{\prime} \mathrm{N} 54^{\circ} 51.1^{\prime} \mathrm{W}$ sandy mud, clay* \\
\hline 117 & $54 \mathrm{~m}$ & $06^{\circ} 55^{\prime} \mathrm{N} 54^{\circ} 54^{\prime} \mathrm{W}$ sandy mud, shells \\
\hline 73 & $55 \mathrm{~m}$ & $06^{\circ} 55^{\prime} \mathrm{N} 53^{\circ} 54.5^{\prime} \mathrm{W}$ sand, mud ${ }^{*}$ \\
\hline 104 & $55 \mathrm{~m}$ & $06^{\circ} 53^{\prime} \mathrm{N} 54^{\circ} 26^{\prime} \mathrm{W}$ mud, glauconite ${ }^{*}$ \\
\hline 64 & $57 \mathrm{~m}$ & $06^{\circ} 55.3^{\prime} \mathrm{N} 56^{\circ} 12.1^{\prime} \mathrm{W}$ sand \\
\hline $67 \mathrm{G}$ & $58 \mathrm{~m}$ & $07^{\circ} 30^{\prime} \mathrm{N} 57^{\circ} 07^{\prime} \mathrm{W}$ sandy calcarenite \\
\hline 40 & $59 \mathrm{~m}$ & $07^{\circ} 02^{\prime} \mathrm{N} 56^{\circ} 26.5^{\prime} \mathrm{W}$ sand \\
\hline 33 & $60 \mathrm{~m}$ & $06^{\circ} 26.2^{\prime} \mathrm{N} 55^{\circ} 56.9^{\prime} \mathrm{W}$ muddy sand \\
\hline 41 & $60 \mathrm{~m}$ & $06^{\circ} 54.8^{\prime} \mathrm{N} 56^{\circ} 28.5^{\prime} \mathrm{W}$ coarse sand \\
\hline 116 & $60 \mathrm{~m}$ & $06^{\circ} 59^{\prime} \mathrm{N} 54^{\circ} 54^{\prime} \mathrm{W}$ sandy mud, shells \\
\hline 103 & $63 \mathrm{~m}$ & $06^{\circ} 58.6^{\prime} \mathrm{N} 54^{\circ} 25^{\prime} \mathrm{W}$ sandy mud \\
\hline 65 & $64 \mathrm{~m}$ & $07^{\circ} 06^{\prime} \mathrm{N} 56^{\circ} 10.7^{\prime} \mathrm{W}$ coarse sand ${ }^{*}$ \\
\hline 66 & $65 \mathrm{~m}$ & $07^{\circ} 06^{\prime} \mathrm{N} 56^{\circ} 10.7^{\prime} \mathrm{W}$ coarse sand \\
\hline
\end{tabular}




\begin{tabular}{|c|c|c|}
\hline 59 & $66 \mathrm{~m}$ & $07^{\circ} 08.5^{\prime} \mathrm{N} 56^{\circ} 57^{\prime} \mathrm{W}$ coarse sand ${ }^{*}$ \\
\hline 24 & $66 \mathrm{~m}$ & $07^{\circ} 04.4^{\prime} \mathrm{N} 55^{\circ} 25^{\prime} \mathrm{W}$ sandy mud, clay* \\
\hline 56 & $68 \mathrm{~m}$ & $07^{\circ} 15.6^{\prime} \mathrm{N} 56^{\circ} 40^{\prime} \mathrm{W}$ coarse sand ${ }^{*}$ \\
\hline 69 & $69 \mathrm{~m}$ & $07^{\circ} 08^{\prime} \mathrm{N} 55^{\circ} 09^{\prime} \mathrm{W}$ coarse sand, mud \\
\hline $63 \mathrm{G}$ & $71 \mathrm{~m}$ & $07^{\circ} 35^{\prime} \mathrm{N} 57^{\circ} 04^{\prime} \mathrm{W}$ sandy bottom \\
\hline 21 & $72 \mathrm{~m}$ & $07^{\circ} 03.8^{\prime} \mathrm{N} 55^{\circ} 40.4^{\prime} \mathrm{W}$ sandy mud \\
\hline 99 & $76 \mathrm{~m}$ & $07^{\circ} 02.5^{\prime} \mathrm{N} 53^{\circ} 52^{\prime} \mathrm{W}$ fine sand, mud, glauconite \\
\hline $62 \mathrm{G}$ & $76 \mathrm{~m}$ & $07^{\circ} 37^{\prime} \mathrm{N} 57^{\circ} 04^{\prime} \mathrm{W}$ shells, dead coral \\
\hline $105 \mathrm{G}$ & $77 \mathrm{~m}$ & $07^{\circ} 50^{\prime} \mathrm{N} 57^{\circ} 30^{\prime} \mathrm{W}$ shell gravel, sand \\
\hline $3 \mathrm{G}$ & $80 \mathrm{~m}$ & $07^{\circ} 02^{\prime} \mathrm{N} 53^{\circ} 35^{\prime} \mathrm{W}$ calcareous sand \\
\hline 102 & $81 \mathrm{~m}$ & $07^{\circ} 11.3^{\prime} \mathrm{N} 54^{\circ} 23^{\prime} \mathrm{W}$ mud, glauconite* \\
\hline $83 \mathrm{G}$ & $83 \mathrm{~m}$ & $07^{\circ} 44^{\prime} \mathrm{N} 57^{\circ} 17^{\prime} \mathrm{W}$ muddy sand \\
\hline 115 & $83 \mathrm{~m}$ & $07^{\circ} 13^{\prime} \mathrm{N} 54^{\circ} 32^{\prime} \mathrm{W}$ coarse sand \\
\hline $31 \mathrm{G}$ & $84 \mathrm{~m}$ & $07^{\circ} 06^{\prime} \mathrm{N} 53^{\circ} 54^{\prime} \mathrm{W}$ sandy mud \\
\hline $105 \mathrm{G}$ & $85 \mathrm{~m}$ & $07^{\circ} 54^{\prime} \mathrm{N} 57^{\circ} 31^{\prime} \mathrm{W}$ muddy sand, gravel \\
\hline 98 & $85 \mathrm{~m}$ & $07^{\circ} 10.6^{\prime} \mathrm{N} 53^{\circ} 50.7^{\prime} \mathrm{W}$ coarse sand ${ }^{*}$ \\
\hline 34 & $85 \mathrm{~m}$ & $07^{\circ} 08.9^{\prime} \mathrm{N} 55^{\circ} 53.8^{\prime} \mathrm{W}$ mud ${ }^{*}$ \\
\hline 112 & $85.5 \mathrm{~m}$ & $07^{\circ} 18.3^{\prime} \mathrm{N} 54^{\circ} 36.3^{\prime} \mathrm{W}$ sandy mud* \\
\hline $96 \mathrm{~A}$ & $86 \mathrm{~m}$ & $07^{\circ} 14^{\prime} \mathrm{N} 54^{\circ} 10^{\prime} \mathrm{W}$ coarse sand ${ }^{*}$ \\
\hline $82 \mathrm{G}$ & $88 \mathrm{~m}$ & $07^{\circ} 45^{\prime} \mathrm{N} 57^{\circ} 17^{\prime} \mathrm{W}$ muddy sand \\
\hline $102 \mathrm{G}$ & $90 \mathrm{~m}$ & $07^{\circ} 53^{\prime} \mathrm{N} 57^{\circ} 28^{\prime} \mathrm{W}$ muddy sand, gravel \\
\hline $57 \mathrm{G}$ & $90 \mathrm{~m}$ & $07^{\circ} 36^{\prime} \mathrm{N} 56^{\circ} 57^{\prime} \mathrm{W}$ sandy mud, shells* \\
\hline 95 & $90.5 \mathrm{~m}$ & $07^{\circ} 17.8^{\prime} \mathrm{N} 54^{\circ} 04^{\prime} \mathrm{W}$ sand, mud* \\
\hline 57 & $94 \mathrm{~m}$ & $07^{\circ} 35.7^{\prime} \mathrm{N} 56^{\circ} 52.6^{\prime} \mathrm{W}$ coarse sand ${ }^{*}$ \\
\hline $60 \mathrm{G}$ & $95 \mathrm{~m}$ & $07^{\circ} 39^{\prime} \mathrm{N} 56^{\circ} 57^{\prime} \mathrm{W}$ sandy mud, shells \\
\hline $2 \mathrm{G}$ & $95 \mathrm{~m}$ & $07^{\circ} 07^{\prime} \mathrm{N} 53^{\circ} 35^{\prime} \mathrm{W}$ sandy calcarenite \\
\hline $59 \mathrm{G}$ & $95.5 \mathrm{~m}$ & $07^{\circ} 38^{\prime} \mathrm{N} 56^{\circ} 57^{\prime} \mathrm{W}$ sandy mud* \\
\hline 23 & $95 \mathrm{~m}$ & $07^{\circ} 17.8^{\prime} \mathrm{N} 55^{\circ} 23.3^{\prime} \mathrm{W}$ calcarenite, coral ${ }^{*}$ \\
\hline $50 \mathrm{G}$ & $96 \mathrm{~m}$ & $07^{\circ} 45^{\prime} \mathrm{N} 57^{\circ} 05^{\prime} \mathrm{W}$ sandy mud* \\
\hline $52 \mathrm{G}$ & $96 \mathrm{~m}$ & $07^{\circ} 41^{\prime} \mathrm{N} 56^{\circ} 59^{\prime} \mathrm{W}$ muddy sand \\
\hline $59 \mathrm{G}$ & $96 \mathrm{~m}$ & $07^{\circ} 38^{\prime} \mathrm{N} 56^{\circ} 57^{\prime} \mathrm{W}$ sandy mud, shells \\
\hline $51 \mathrm{G}$ & $98 \mathrm{~m}$ & 07, fo $4241^{\prime} \mathrm{N} 57^{\circ} 01^{\prime} \mathrm{W}$ sandy mud \\
\hline $114 \mathrm{C}$ & $105 \mathrm{~m}$ & $07^{\circ} 24.6^{\prime} \mathrm{N} 54^{\circ} 49.7^{\prime} \mathrm{W} \mathrm{mud}^{*}$ \\
\hline $81 \mathrm{G}$ & $120 \mathrm{~m}$ & $07^{\circ} 51^{\prime} \mathrm{N} 57^{\circ} 15^{\prime} \mathrm{W}$ sandy mud \\
\hline 101 & $120 \mathrm{~m}$ & $07^{\circ} 25.4^{\prime} \mathrm{N} 54^{\circ} 20.5^{\prime} \mathrm{W}$ coarse sand, mud ${ }^{*}$ \\
\hline 37 & $121 \mathrm{~m}$ & $07^{\circ} 24.6^{\prime} \mathrm{N} 56^{\circ} 22.4^{\prime} \mathrm{W}$ mud, shells* \\
\hline $93 \mathrm{~A}$ & $125 \mathrm{~m}$ & $06^{\circ} 22^{\prime} \mathrm{N} 55^{\circ} 00^{\circ} \mathrm{W}$ Agassiz trawl \\
\hline 97 & $130 \mathrm{~m}$ & $07^{\circ} 18.5^{\prime} \mathrm{N} 53^{\circ} 48.7^{\prime} \mathrm{W}$ coarse sand ${ }^{*}$ \\
\hline $101 \mathrm{~A}$ & $132 \mathrm{~m}$ & $07^{\circ} 25.4^{\prime} \mathrm{N} 54^{\circ} 20.5^{\prime} \mathrm{W}$ subfossil reefs ${ }^{*}$ \\
\hline $114 \mathrm{~A}$ & $132 \mathrm{~m}$ & $07^{\circ} 26^{\prime} \mathrm{N} \cdot 54^{\circ} 39.7^{\prime} \mathrm{W}$ muddy sand \\
\hline $114 \mathrm{~B}$ & $138 \mathrm{~m}$ & $07^{\circ} 24.6^{\prime} \mathrm{N} 54^{\circ} 49^{\prime} \mathrm{W}$ muddy sand ${ }^{*}$ \\
\hline 98 & $207 \mathrm{~m}$ & $07^{\circ} 28^{\prime} \mathrm{N} 54^{\circ} 03.1^{\prime} \mathrm{W}$ soft mud ${ }^{*}$ \\
\hline 22 & $240 \mathrm{~m}$ & $07^{\circ} 21.6^{\prime} \mathrm{N} 55^{\circ} 22.2^{\prime} \mathrm{W}$ heavy clay* \\
\hline 113 & $254 \mathrm{~m}$ & $07^{\circ} 30.2^{\prime} \mathrm{N} 54^{\circ} 35^{\prime} \mathrm{W}$ mud* \\
\hline 36 & $400 \mathrm{~m}$ & $07^{\circ} 26.8^{\prime} \mathrm{N} 56^{\circ} 21.8^{\prime} \mathrm{W}$ soft mud* \\
\hline $48 \mathrm{G}$ & $500 \mathrm{~m}$ & $07^{\circ} 45^{\prime} \mathrm{N} 57^{\circ} 0 \mathrm{I}^{\prime} \mathrm{W}$ Agassiz trawl \\
\hline 13 & $940 \mathrm{~m}$ & $07^{\circ} 26.8^{\prime} \mathrm{N} 55^{\circ} 04.3^{\prime} \mathrm{W}$ soft mud* \\
\hline
\end{tabular}




\section{AlPHABETIC LiST OF SPECIES FOUND IN THE SAMPLES}

After the species names follow the station numbers and, in parentheses, the depths in meters and an indication of abundance $(\mathrm{a}=$ abundant, more than 10 specimens; $\mathrm{c}=$ common, $4-10$ specimens; $\mathrm{r}=$ rare, $1-3$ specimens per sample) $+=$ described and figured in this paper; ${ }^{*}=$ new species.

+ Ammobaculites agglutinans (d'Orbigny): 36 (400 r), 13 (940 r).

+ Ammobaculites americanus (Cushman): 61 (33 r), $110(46.5 \mathrm{r}), 111$ (51.5 r), $104(55 \mathrm{r}), 73(55 \mathrm{r}$ ), 102 (81 a), 96 (207 a), 113 (254 r), 36 (400 r), 13 (940 c).

Ammodiscus planus Höglund: 13 (940 r).

Ammolagena clavata (Parker \& Jones): $48 \mathrm{G}(500$ a).

Ammonia tepida (Cushman): 83 (19.5 c), $72(25 \mathrm{c}), 45(27 \mathrm{c}), 51$ (29 a), 18 (30 a), 17 (31 r), 61 (35 c), 3 (36 a), 44 (38 c), 19A (38 r).

+ Amphicoryna catesbyi (d’Orbigny): 3 (36 c), 86 (42 c). 2 (46.5 c). 89 (51.5 r). 65 (64 c).

Amphicoryna roederi Andersen: 37 (r), 22 (240 r), $35(400 \mathrm{r})$.

+ Amphicoryna rugosa (d'Orbigny): 22 (240 c), $113(254 \mathrm{r}), 36$ (400 c).

Amphorina mollis (Cushman): 22 (240 r).

Amphorina purii Andersen: 22 (240 r), 113 (254 r).

Angulogerina bella Phleger \& Parker: 34 ( 85 a).

Aschemonella scabra Brady: 56 (400 r), 13 (940 r).

+ Asterorotalia rolshauseni (Cushman \& Bermúdez): 14 (18 a), 83 (19.5 c). 72 (25 a), 45 (27 a). 18 (30 a), 67 (30 a), 17 (3l c), 122 (32 c), 61 (35 a), 3 (36 c), 91 (37.5 a), 31 (38 c), 19A (38 r), 54 $(38 \mathrm{r}), 52(39 \mathrm{c}), 55(45 \mathrm{r}), 90(45 \mathrm{c})$.

Biarritzina proteiformis (Goës): 87 (35.5 r), 40G (43 c), 5G (44 a), 39G (45 a), $75(50 \mathrm{r}), 24(66 \mathrm{r})$, 56 (68 c), 62G (76 a), 105G (77 a), $102(81 \mathrm{r}), 83 \mathrm{G}(82 \mathrm{a}), 3 \mathrm{IG}(84 \mathrm{a}), 98(85 \mathrm{a}), 93 \mathrm{~A}(86 \mathrm{c})$, $82 \mathrm{G}(88 \mathrm{c}), 112(88.5 \mathrm{c}), 57 \mathrm{G}(90 \mathrm{a}), 102 \mathrm{G}(90 \mathrm{a}), 95(90.5 \mathrm{c}), 2 \mathrm{G}(93 \mathrm{a}), 60 \mathrm{G}(95 \mathrm{a}), 52 \mathrm{G}(96 \mathrm{a})$, $114 \mathrm{G}(105 \mathrm{c}), 8 \mathrm{IG}(120 \mathrm{c}), 101$ (120 r), $101 \mathrm{~A}$ (132 a).

Bigenerina irregularis Phleger \& Parker: 45 (27 c). 43 (37 a), 91 (37.3 c). 31 (38 c). 54 (38 a). 70 (40 c), 119 (41.5 r), 55 (45 c), 90 (45 a), 88 (46 c), 110 (46 a), 20 (46.5 c), 4 (48 c), 32 (48.5 a), 2 (51 c), 89 (51.5 a), 111 (51.5 c), 65 (64 r), 56 (68 c), $102(81 \mathrm{r}), 103 \mathrm{G}(85 \mathrm{c}), 96 \mathrm{~A}(86 \mathrm{c}), 57$ (94 c).

+ Bolivina mexicana Cushman: 101 (120 a). 114A (132 c), 96 (207 a), $22(240 \mathrm{r}), 36(400 \mathrm{c}), 13$ $(940 \mathrm{r})$.

Bolivina fragilis Phleger \& Parker: 36 (400 r).

+ Bolivina goesii Cushman: 101 (120 c), 97 (130 r), 114A (132 c), 114B (138 r).

Bolivina lanceolata Parker: 18 (30 r), $3(36$ r). 44 (38 r), 52 (39 c), 55 (45 c). 20 (46.5 r).

Bolivina subspinescens Cushman: 114A (132 r).

Bolivina translucens Phleger \& Parker: 114A (132 c).

+ Bulimina aculeata d'Orbigny: 36 (400 a), 13 (940 a).

+ Bulimina alazanensis Cushman: 36 (400 r), 13 (940 a).

Bulimina clava Cushman: 36 (400 c).

+ Bulimina marginata d'Orbigny: 114A (132 r), 96 (207 c), 113 (254 a), 13 (940 c).

Bulimina mexicana Cushman: 13 (940 a).

+ Bulimina spicata Phleger \& Parker: 113 (254 c), 13 (940 c).

+ Cancris sagrai (d’Orbigny): 45 (27 r), 51 (29 r), 61 (35 c), 3 (36 a), 31 (38 a), 19A (38 c), 52 (39 c), $30(41 \mathrm{r}), 20(46.5 \mathrm{r}), 32(48.5 \mathrm{c}), 2(51 \mathrm{r}), 104(35 \mathrm{c}), 105(63 \mathrm{c}), 24$ (66 c).

Cancris oblongus (Williamson): 111 (51.5 c), $68(68 \mathrm{r}), 102(81 \mathrm{r}), 95 \mathrm{G}(95.5 \mathrm{c}), 101(120 \mathrm{r}), 114 \mathrm{~A}$ (132 c).

Carpenteria monticularis (Carter): $62 \mathrm{G}(76 \mathrm{c}), 31 \mathrm{G}(84 \mathrm{c}), 98(85 \mathrm{r}), 57 \mathrm{G}(96 \mathrm{r}), 50 \mathrm{G}(96 \mathrm{c})$.

Carpenteria utricularis (Carter): 60G (95 c), 52G (96 r), 114G (105 r), 50G (96 a).

Cassidulina subglobosa Brady: 101 (120 c).

Cassidulinoides tenuis Phleger \& Parker: 36 (400 r), 13 (940 c).

Cibicides antilleanus Drooger: 23 (95 c), $95 \mathrm{G}(95.5 \mathrm{a}), 114 \mathrm{C}$ (105 r), 101 (120 c), 37 (121 a), 97 (130 a), $101 \mathrm{~A}(132 \mathrm{c}), 114 \mathrm{~B}$ (138 a), 36 (400 c), 36 (400 c), 23 (95 c). 
Cibicides deprimus Phleger \& Parker: $19 \mathrm{G}$ (42 r), 40G (43 c), 55 (45 r), 90 (45 r), 20 (46.5 c), 59 (49 r), 2 (5l r), $104(55$ r), 66 (65 c), 24 (66 a), 56 (68 a), 69 (69 a), 21 (72 r), 102 (81 a), 34 (85 a), 96A (86 a). 57 (94 r). 97 (130 r).

Cibicides mollis Phleger \& Parker: 23 (95 a). 101 (120 a), 37 (121 c), 97 (130 a), 113 (254 a).

Cibicides pseudoungerianus Cushman: 114C (105 a, 101 (120 c), 96 (207 c), 22 (240 a), 113 (245 a), 36 (400 a), 13 (940 a).

Cibicides robustus Phleger \& Parker: 23 (95 c), 114C (105 c), 97 (130 r), 114A (132 a), 36 (400 a).

Cibicides rugosus Phleger \& Parker: 58 (66 c), 97 (130 c).

Cornuspiramia antillarum (Cushman): 32 (48.5 c), 112 (88.5 c), 23 (95 r).

Cyclammina cancellata Brady: $48 \mathrm{G}$ (500 a).

Cylindroclavulina bradyi Bermúdez: $103 \mathrm{G}(85 \mathrm{c}), 34(85 \mathrm{c})$.

+ Dentalina bradyensis Dervieux: 114B (138 r).

Dentalina communis d'Orbigny: $82 \mathrm{G}(88 \mathrm{c}), 22(240 \mathrm{c}), 36(400 \mathrm{c})$.

Dentalina filiformis d'Orbigny: $56 \mathrm{G}(86 \mathrm{r}), 2 \mathrm{G}(93 \mathrm{r}), 101$ (120 r), 114A (132 r), 114B (138 r).

Dimorphina peregrina (Schwager): 114A (132 r), 22 (240 r), 36 (400 a), 36 (940 r).

Discammina compressa (Goës): 96 )207 r), 36 (400 r), 13 (940 r).

Dorothia scabra (Brady): 22 (240 r).

Ehrenbergina spinea (Cushman): $27(121 \mathrm{r})$.

Ehrenbergina trigonalis (Goës): 36 (400 c), 13 (940 c).

Elphidium galvestonense (Kornfeld): 45 (27 c), 51 (29 a), 122 (32 c), 103 (33 a), 3 (36 a), 44 (38 c), 19A (38 a), 54 (38 c), 52 (39 a), 70 (40 c), $30(41 \mathrm{r}), 119$ (41.5 c), 19G (42 r), 96 (42 a), 40G (43 c), 5G (44 r), 90 (45 c), 20 (46.5 a), 4 (48 a), 2 (51 c), $104(55 \mathrm{a}), 102(81 \mathrm{c}), 96 \mathrm{~A}(85 \mathrm{c})$.

+ Eponides antillarum (d'Orbigny): 14 (18 c), 79 (27 r), 45 (27 a), 51 (29 a), 18 (30 c), 67 (30 a), 17 $(31 \mathrm{c}), 122(32 \mathrm{c}), 87(33.5 \mathrm{c}), 61(35 \mathrm{r}), 80(35.5 \mathrm{r}),(36 \mathrm{c}), 43(37 \mathrm{a}), 91(37.3 \mathrm{c}), 31(38 \mathrm{a}), 19 \mathrm{~A}$ (38 a), 54 (38 a), 52 (39 c), 112G (39 c), 70 (40 a), 30 (41 a), 70G (41 a), 119 (41.5 c), 19G (42 r), 86 (42 r), 40G (43 a), 5G (44 c), 39G (45 r), 55 (45 a), 90 (45 c), 110 (46.5 a), 20 (46.5 a), 4 (48 a), 32 (48.5 a), 59 (49 a), 2 (5l a), 89 (51.5 a), 111 (5l.5 a), $104(55$ a), 73 (55 a), 41 (60 a), 103 (63 c), 65 (64 a), 58 (66 a), 24 (66 c), $56(68 \mathrm{a}), 69$ (69 a), 21 (72 a), 102 (81 a), 98 (86 c), 34 (85 a), $96(86$ a), 112 (88.5 a), 95 (90.5 a), 2G (93 a), 57 (94 r), 23 (95 a), 95G (95.5 c), $50 \mathrm{G}$ (96 c), $114 \mathrm{C}(105 \mathrm{c}), 81 \mathrm{G}(120 \mathrm{r}), 101(120 \mathrm{c}), 97(130 \mathrm{r}), 114 \mathrm{~A}(132 \mathrm{a}), 101 \mathrm{~A}(132 \mathrm{r}), 114 \mathrm{~B}(138 \mathrm{c})$.

+ Eponides campester Palmer \& Bermúdez: 96 (207 r), 22 (240 a), 36 (400 c).

+ Eponides lateralis (Terquem): 81 (8 a), 14 (18 a), 83 (19.5 a), 82 (22.2 a), 79 (27 a), 72 (27 c), 45 (27 a), 51 (29 a), 18 (30 c), 67 (30 a), 17 (31 a), 122 (32 a), 87 (33.5 c), 80 (35.5 c), 3 (36 c), 43 (37 a), 31 (38 a), 44 (38 a), 19A (38 c), 54 (38 a), 52 (39 a), 112G (39 c), 30 (4l c), $70 \mathrm{G}(41 \mathrm{c})$, I $19(41.5 \mathrm{c}), 19 \mathrm{G}(42 \mathrm{r}), 86(52 \mathrm{c}), 40 \mathrm{G}(43 \mathrm{a}), 5 \mathrm{G}(44 \mathrm{c}), 39 \mathrm{G}(45 \mathrm{r}), \mathrm{I} 1 \mathrm{I}(5 \mathrm{l} .5 \mathrm{c}), 73(55 \mathrm{c}), 4 \mathrm{l}$ $(60 \mathrm{r}), 66(65 \mathrm{c}), 24(66 \mathrm{c}), 21(72 \mathrm{r}), 98(85 \mathrm{r}), 34(85 \mathrm{c}), 23(95 \mathrm{r})$.

Eponides regularis Phleger \& Parker: $36(400 \mathrm{c})$.

+ Eponides repandus (Fichtel \& Moll): 87 (33.5 r), 65 (68 c), 98 (85 a), $57 \mathrm{G}$ (90 r), 2G (93 c), 57 $(94 \mathrm{c}), 95 \mathrm{G}(95.5 \mathrm{c}), 50 \mathrm{G}(96 \mathrm{c})$.

Euuvigerina flintii (Cushman): 97 (130 c), 114A (132 r), 114B (138 r).

Euuvigerina hispidocostata Cushman \& Todd: 22 (240 a), 113 (245 a), 36 (400 a).

Euuvigerina parvula (Cushman): 114A (132 a), 36 (400 a).

Euuvigerina peregrina (Cushman): 13 (940 a).

Fissurina orbignyana (Seguenza): 114A (132 c), 13 (940 r).

Flintia robusta (Brady): 96 (207 r).

+ Flintina bradyana Cushman: 67 (34 a), 61 (35 c), 91 (37.5 a), 52 (39 r), 112 G (39 r), 70 (40 a), 30 $(4 \mathrm{l} \mathrm{c}), 119(41.5 \mathrm{r}), 19 \mathrm{G}(42 \mathrm{r}), 40 \mathrm{G}(43 \mathrm{a}), 56(44 \mathrm{r}), 90(45 \mathrm{a}), 110(46.5 \mathrm{c}), 111(51.5 \mathrm{r}), 73(55$ a), $104(55 \mathrm{r}), 69(69 \mathrm{r}), 102(81 \mathrm{c}), 98(85 \mathrm{c}), 96 \mathrm{~A}(86 \mathrm{a})$.

+ Frondicularia sagittula Van den Broeck: $105 \mathrm{G}$ (77.6 c), 3G (80 a), 102 (81 c), 103G (85 c), 98 $(85 \mathrm{c}), 34(85 \mathrm{c}), 56 \mathrm{G}(86 \mathrm{a}), 96 \mathrm{~A}(96 \mathrm{c}), 82 \mathrm{G}(88 \mathrm{a}), 112(88.5 \mathrm{r}), 57 \mathrm{G}(90 \mathrm{a}), 102 \mathrm{G}(90 \mathrm{a}), 95$ $(90.5 \mathrm{c}), 2 \mathrm{G}(95 \mathrm{c}), 60 \mathrm{G}(95 \mathrm{c}), 23(95 \mathrm{r}), 50 \mathrm{G}(96 \mathrm{a}), 114 \mathrm{C}(105 \mathrm{c}), 101(120 \mathrm{r}), 97(130 \mathrm{r}), 114 \mathrm{~A}$ (132 c).

Gaudryina atlantica Cushman: 114B (138 c), 96 (207 a), 22 (240 a), 113 (254 a). 
* Glandulina surinamensis nov. spec.: 45 (27 r), 51 (29 r), $18(30$ r), 61 (35 c), 3 (36 a), 43 (37 r), $70(40$ r), $30(41$ r), $55(45$ r), 90 (45 r), $20(46.5$ c), 91 (37.3 r). $32(48.5$ c), $111(51.5$ r $), 24(66$ r).

+ Glandulina torrida Cushman: 13 (940 c).

* + Globocassidulina aperta nov. spec.: $98(85 \mathrm{r}) .34(85 \mathrm{r}) .112(88.5 \mathrm{r}), 2 \mathrm{G}(93 \mathrm{r})$.

Goesella flintii Cushman: 22 (240 c).

Gyroidina aliformis Stewart \& Stewart: $36(400 \mathrm{c})$.

+ Hanzawaia concentrica (Cushman): 14 (18 c), 79 (27 a), 45 (27 a), 51 (29 a), 18 (30 c), 67 (30 a), $17(31 \mathrm{c}), 61(35 \mathrm{c}), 80(34.5 \mathrm{r}), 43(37 \mathrm{a}) .31$ (38 a), 19A (38 a), $54(38 \mathrm{a}) .52(39 \mathrm{a}), 70(40 \mathrm{a}), 30$ (41 a), 119 (41.5 a). 19G (42 c). 86 (42 a). 40G (43 c). 5G (44 c). 55 (45 a). $110(46.5 \mathrm{c}), 20$ (46.5 a), $4(48$ a), 59 (49 c), $2(51.5$ a), $89(51.5$ a), $111(51.5$ a), $104(55 a), 41(60 \mathrm{c}), 105$ (63 c), 69 (69 c). 21 (72 c). 102 (81 a). 34 (85 c), 95 (90.5 c), 114A (132 a), 113 (254 c).

Heterostegina antillarum d'Orbigny: 51 (29 r), 43 (37 r). 44 (38 r). $54(38$ c). $70 \mathrm{G}$ (4l a), 40 (43 r). $55(45 \mathrm{c}), 20(46.5 \mathrm{r}), 105 \mathrm{G}(77.6 \mathrm{c}), 103 \mathrm{G}(85 \mathrm{c}), 57 \mathrm{G}(90 \mathrm{r}), 102 \mathrm{G}(90 \mathrm{r})$.

Hoeglundina hyalina Hofker: 22 (240 a), 36 (400 a), 13 (940 c).

+ Homotrema rubrum (Lamarck): $62 \mathrm{G}$ (76 r), 98 (85 r). 60G (95 c), $50 \mathrm{G}$ (96 a), $101 \mathrm{~A}(132 \mathrm{r}$ ).

Hyperammina caribbeana Hofker: $22(24 \mathrm{c})$.

Hyperammina subnodosa Brady: 98 ( $85 \mathrm{c})$.

Karreriella bradyi Cushman: $114 \mathrm{G}$ (105 r), 22 (240 r), $36(400 \mathrm{c}), 13$ (940 c).

Labrospira subglobosa (Sars): 113 (254 r).

Laticarinina bulbrooki Cushman \& Todd: $13(940 \mathrm{c})$.

+ Lenticulina antillea (Cushman): 73 (55 r), 102 (81 c), $98(85 \mathrm{r}), 103 \mathrm{G}(85 \mathrm{r}), 56 \mathrm{G}(86 \mathrm{a}), 96 \mathrm{~A}$ (86 c), $82 \mathrm{G} \mathrm{(88} \mathrm{a),} 112(88.5 \mathrm{r}), 75 \mathrm{G}(90 \mathrm{a}), 95(90.5 \mathrm{r}), 2 \mathrm{G}(93 \mathrm{a}), 60 \mathrm{G}(95 \mathrm{r}), 50 \mathrm{G}(96 \mathrm{r}), 52 \mathrm{G}$ (96 c), $114 \mathrm{C}(105 \mathrm{c}), 37(121 \mathrm{r}), 97(130 \mathrm{r}), 114 \mathrm{~A}(132 \mathrm{r})$.

Lenticulina atlantica (Barker): 34 (85 r), $112(88.5 \mathrm{c}), 101$ (120 r).

+ Lenticulina calcar (Linnaeus): 101 (120 r), 97 (130 c), I14B (138 c), 96 (207 r), 122 (240 a), 113 $(254 \mathrm{c}), 36(400 \mathrm{c})$.

Lenticulina cultrata (Montfort): $112(88.5 \mathrm{c}), 101$ ( $120 \mathrm{r})$.

Lenticulina dorbignyi (Cushman): $52 \mathrm{G}$ (96 a)

Lenticulina falcifer (Stache): 2G (93 c), $37(120 \mathrm{c}), 114 \mathrm{~B}(138 \mathrm{r})$.

+ Lenticulina formosa (Cushman): $36(400 \mathrm{r})$.

+ Lenticulina iota (Cushman): $112(88.5 \mathrm{c}), 114 \mathrm{C}(105 \mathrm{c}), 101(120 \mathrm{r}), 97$ (130 c), 114A (132 a), 114B (138 c), 96 (207 a), 22 (240 a), 113 (254 a), 36 (400 a), 36 (400 a), 48G (500 a), 13 (940 c).

Lenticulina lowmanni Andersen: 90 (43 r). $73(55 \mathrm{a}), 102(8 \mathrm{l} \mathrm{c}), 98(85 \mathrm{c}), 34(85 \mathrm{c}), 96 \mathrm{~A}(86 \mathrm{r}), 112$ $(88.5 \mathrm{c}), 2 \mathrm{G}(93 \mathrm{c}), 23(95 \mathrm{a}), 95 \mathrm{G}(95.5 \mathrm{c}), 114 \mathrm{C}(105 \mathrm{r}), 101(120 \mathrm{c}), 97(12 \mathrm{l})$.

Lenticulina occidentalis (Cushman): 2G (93 a), 60G (95 c), $22(240 \mathrm{c}), 113(254 \mathrm{a}), 36(400 \mathrm{a})$.

Lenticulina septemtrionalis (Cushman): 105G (77.6 r), 56G (86 r). 50G (96 r). 37 (121 c).

* Liebusella arenosa nov. spec.: 43 (37 r), 54 (38 c), 52 (39 c), $70(40 \mathrm{c}), 70 \mathrm{G}(41 \mathrm{a}), 55(45 \mathrm{c}), 90$ (45 c), 110 (46.5 a), 20 (46.5 c), 4 (48 a), 32 (48.5 c), 59 (49 a), 2 (51 a), 89 (51.5 c), 111 (51.5 a), 104 (55 r). 75 (55 a), 4 I (60 c), 105 (63 r), 65 (64 a), 66 (65 r), 58 (66 a, A + B), 24 (66 a), 56 (68 a), 69 (69 a, A + B), 21 (72 a), 62G (76 a), 105G (77.6 c), 83G (82 a), 98 (85 c), 103G (85 a), 35 $(85 \mathrm{a}, \mathrm{A}+\mathrm{B}), 82 \mathrm{G}(88 \mathrm{c}), 57 \mathrm{G}(90 \mathrm{a}, \mathrm{A}+\mathrm{B}), 95(90.5 \mathrm{a}, \mathrm{A}+\mathrm{B}), 60 \mathrm{G}(95 \mathrm{a}), 23(95 \mathrm{c}), 52 \mathrm{G}(96$ a), $114 \mathrm{C}(105 \mathrm{a}), 81 \mathrm{G}(120 \mathrm{a}), 101(120 \mathrm{a}), 37(121 \mathrm{c}), 97(130 \mathrm{a}), 101 \mathrm{~A}(132 \mathrm{a}, \mathrm{A}+\mathrm{B}), 114 \mathrm{~B}$ $(138 \mathrm{c}), 22(240 \mathrm{c})$. The indication $A+B$ points to the existence of both micro- and megalospheric specimens in the sample.

* + Liebusella eleganta nov. spec.: 110 (46.5 r), 111 (51.5 r), 73 (55 a), 24 (66 a), 69 (69 a), 21 (2 c), 102 (81 a), 98 (85 c). 34 (85 c), 96A (86 c). 112 (88.5 a), 95 (90.5 r). 57 (94 c. A + B), 23 (95 a). The indication $\mathrm{A}+\mathrm{B}$ points to both generations occurring in the sample.

Liebusella flintiana Cushman: 113 (254 r).

*+ Marginulina anderseni nov. spec.: 119A (38 r), 32 (48.5 r), 66 (65 r), 58 (66 r), 24 (66 r), 69 (96 r).

Marginulina bachei (Goës): $2 \mathrm{G}$ (93 r), 57 (94 r), 50G (96 r).

Marginulina bradyi Goës: $50 \mathrm{G}(96 \mathrm{r})$.

+ Marginulina glabrata (Cushman): 96 (207 a), 22 (240 a), 113 (254 r), 36 (400 a).

+ Marginulina planata Phleger \& Parker: 40G (43 r), 90 (45 r), 2 (51 r), 89 (51.5 r), 111 (51.5 r), 
73 (55 a), 65 (64 r), 58 (66 r), 24 (66 a). 65 (68 c), 69 (69 a), 21 (7l c), 105G (77.5 r), 102 (81 c). 98 ( 85 a), 56G (86 c), 96A ( 86 a), 112 (88.5 c), 57 (90 r), 95 (90.5 a), 2G (93 a). 57 (94 c). 25 (95 a), 95 (95.5 a), 50G (96 a), 37 (121 c). 97 (130 r), 101 A (132 r).

Marginulina striatula Cushman: 24 (66 r).

+ Marginulina subaculeata Cushman: 114C (105 a), 97 (130 r), 114B (138 c).

+ Marginulina tenuis Bornemann: 22 (240 a), 36 (400 a).

Martinotiella antillarum (Cushman): 37 (121 r), 114A (132 r).

Martinottiella undulosa (Cushman): 36 (400 c).

Martinottiella occidentalis Cushman: 13 (940 c).

+ Martinotiella pallida (Cushman): 36 (400 a), 13 (940 c).

Massilina crenata (Karrer): 55 (45 r).

Miliolinella subrotunda (Montagu): 43 (27 c), 18 (30 r), 31 (38 c), 52 (39 r), 55 (45 r), 20 (46.5 c), 32 $(48.5 \mathrm{c})$.

Mississippina concentrica (Parker \& Jones): 37 (12l c), 97 (130 r). 114A (132 r).

Neouvigerina auberiana (d'Orbigny): $36(400 \mathrm{c})$.

*+ Nodobacularia pusiulosa nov. spec.: $31 \mathrm{G}(84 \mathrm{r}), 98(85 \mathrm{c}), 56 \mathrm{G}(86 \mathrm{c})$.

Nodobaculariella atlantica Cushman \& Habzawa: 51 (29 r), 19A (38 r), 52 (39 r), 55 (45 r). 20 (46.5 r).

Nodosaria albatrossi Cushman: 102 (8I r), 96A (86 r), 112 (88.5 c), 114A (132 c).

Nodosaria flintii Cushman: $102(81 \mathrm{r}), 83 \mathrm{G}(82 \mathrm{r}), 103 \mathrm{G}(85 \mathrm{a}), 56 \mathrm{G}(86 \mathrm{c}), 82 \mathrm{G}(88 \mathrm{c}), 57 \mathrm{G}(90 \mathrm{c})$. $102 \mathrm{G}(90 \mathrm{c}), 2 \mathrm{G}(93 \mathrm{c}), 57(94 \mathrm{r}) .60 \mathrm{G}(96 \mathrm{a}), 52 \mathrm{G}(96 \mathrm{a}), 101(120 \mathrm{r}), 37$ (121 r). $114 \mathrm{~B}(138 \mathrm{c})$. $96(207 \mathrm{a}), 22(240 \mathrm{c}), 113(254 \mathrm{c})$.

Nodosaria fusta Cushman \& Todd: $113(254 \mathrm{c})$.

Nodosaria pyrula d'Orbigny: 96A (86 r), 114C (105 r), 101 (120 r), 114A (132 r), 96 (207 c), 22 (240 c).

Nodosaria subsoluta Cushman: $27(121 \mathrm{r}), 13(940 \mathrm{r})$

Nonionella atlantica (Cushman): 83 (19.5 c), 72 (25 r), 45 (27 a), 51 (29 c), 18 (30 c), 67 (30 c), 17 (31 r), 61 (35 a), $80(35.5$ r), 3 (36 a), 43 (37 c), 91 (37.3 c), 31 (38 a), 44 (38 r), 18A (38 a), 54 (38 r), 52 (39 a), 70 (40 a), 30 (4l r), $119(41.5 \mathrm{r}), 19 \mathrm{G}(42 \mathrm{r}), 86(42 \mathrm{c}), 40 \mathrm{G}(43 \mathrm{r}), 55(45 \mathrm{c}), 20$ $(46.5 \mathrm{c}), 32(48.5 \mathrm{c}), 89(51.5 \mathrm{r}), 111(51.5 \mathrm{r}), 103(63 \mathrm{a}), 24(66 \mathrm{r}), 102(81 \mathrm{c}), 34(85 \mathrm{r}), 97(130$ r), 114A (132 a).

Osangularia culter (Parker \& Jones): 13 (940 a).

Placopsilina confusa Cushman: $62 \mathrm{G}$ (76 c), 98 (85 c).

Planogypsina squamiformis Cushman: $56(68 \mathrm{r})$.

+ Planorbulina caribbeana Hofker: 51 (29 r), 67 (30 c), 80 (25.5 r), 3 (36 a), 43 (37 r), 31 (38 a), 54 (38 a), 5G (44 r), 55 (45 r), 20 (46.5 a). $4(48$ a). 32 (48.5 c), 59 (49 c), 2 (51 a). 65 (64 r). 58 (66 c), $24(66 \mathrm{a}), 56(68 \mathrm{a}), 69(69 \mathrm{r}), 98(85 \mathrm{c}), 34(85 \mathrm{c}), 96 \mathrm{~A}(86 \mathrm{a}), 2 \mathrm{G}(93 \mathrm{c}), 57(94 \mathrm{r}), 97$ (130 c), $113(254 \mathrm{r}), 36(400 \mathrm{c})$.

Planulina ariminensis (d'Orbigny): 22 (240 c), 113 (254 c), 36 (400 r).

Planulina foveolata Brady: 101 (120 c), 97 (130 a), 114A (132 a), 101A (132 c), 114B (138 a), 22 $(240 \mathrm{c}), 113(254 \mathrm{c}), 36(400 \mathrm{r})$.

Praemassilina arenaria (Brady): 22 (240 r).

Proteonina atlantica Cushman: 73 (55 a).

Proteonina difflugiformis (Brady): 36 (400 c).

+ Protoglobobulimina turgida (Bailey): 22 (240 a), 113 (254 a), 13 (940 c).

Pseudoclavulina mexicana (Cushman); 101 (120 a), 97 (130 a), 114A (132 a), 114B (138 c), 96 (207 a), 22 (240 a), 36 (400 a).

Pseudonodosaria comatula Cushman: 37 (112 c), 22 (240 c).

Pseudopolymorphina fischeri (Terquem): 31 (38 r).

Pseudopyrgo eburnea (d'Orbigny): 3 (36 r), 43 (37 r).

Pullenia bulloides (d'Orbigny): 101 (120 r).

Pullenia quadriloba Cushman \& Todd: 95G (95.5 r).

Pyrgo carinata (d'Orbigny): 101 (120 r).

Pyrgo depressa (d'Orbigny): 113 (254 c). 
Plrgoides denticulatus (Brady): 97 (130 r).

Pirgoides nasumus (Cushman): 14 (18 r). 3 (36 r). 91 (37.3 r). 31 (38 a). 19A (38 r), 30 (4l r), 39G $(45$ r). 90 (45 a). 88 (46 r). $110(46.5$ r). 4 (48 c), 2 (5I r). 111 (5l.5 c), 73 (55 a). 103 (63 r), 24 $(66$ a). 69 (69 r), $96 \mathrm{~A}(86 \mathrm{c}), 96$ (207 a).

Quinqueloculina auberiana d’Orbigny: 45 (27 a). 51 (29 a), $87(33.5 \mathrm{c}), 3(36 \mathrm{c}), 43$ (37 r), 31 (38 a), $44(38 \mathrm{c}) .19 \mathrm{~A}(38 \mathrm{r}) .52$ (39 c). 86 (42 r). $35(45 \mathrm{c}) .20$ (46.5 c), 32 (48.5 c). 59 (49 c). 2 (5l c), 65 $(64 \mathrm{c}) .58(66 \mathrm{c}) .56(68 \mathrm{c}) .34(85 \mathrm{c})$.

Quinqueloculina bicostata d'Orbigny: 14 (18 c), 83 (19.5 c), 79 (27 r), 45 (27 a), 51 (29 a), 18 (30 c), $67(30 \mathrm{a}) .17(31 \mathrm{c}) .61(35 \mathrm{c}) .80(35.5 \mathrm{c}) .91(37.3 \mathrm{a}) .31(38 \mathrm{a}) .44(38 \mathrm{a})$. 19A (38 c). $54(38 \mathrm{a})$, $52(39 \mathrm{c}), 112 \mathrm{G}(39 \mathrm{c}), 70(40 \mathrm{c}), 30(41 \mathrm{c}), 119(41.5 \mathrm{a}), 19 \mathrm{G}(42 \mathrm{a}), 86(42 \mathrm{c}), 40 \mathrm{G}(43 \mathrm{a}), 5 \mathrm{G}$ (44 c). 39G (45 c). 55 (45 c). 90 (45 c), 110 (46.5 a), 20 (46.5 a), 4 (48 a), 32 (48.5 c), 59 (49 r), 2 $(51 \mathrm{c}) .89$ (51.5 a). $104(55 \mathrm{c}) .73$ (55 a). 41 (60 c). 66 (65 r). 56 (68 c). 69 (69 a), 21 (72 c). 102 (81 г). 98 (85 a).

+ Quinqueloculina horrida Cushman: 19A (38 r), 55 (45 r), 2 (51 r), 90 (45 r), 111 (51.5 c), 104 (55 a). $73(55 \mathrm{c}) .103$ (63 r). 65 (64 r). 66 (65 r). 58 (66 c), 24 (66 a). 69 (69 a), 21 (72 c), 102 (81 r). 112 (88.5 c). $57 \mathrm{G}(90 \mathrm{r}) .57(94 \mathrm{a}) .23(95 \mathrm{c})$.

Quinqueloculina lamarckiana (d'Orbigny): 14 (18 c), 83 (19.5 c), 72 (25 c), 51 (29 a), 18 (30 c), 67 (30 a). $17(31$ r), 122 (32 c). 87 (33.5 c), 3 (36 c). 43 (37 r), 91 (37.3 a), 31 (38 a), $44(38 \mathrm{c}), 19 \mathrm{~A}$ $(38$ c). 54 (38 a). $112 \mathrm{G}(39$ c). 70 (40 a). 30 (41 c). 119 (41.5 a), 19G (42 c), $86(42$ a), $40 \mathrm{G}(43$ a), $5 \mathrm{G} \mathrm{(44} \mathrm{r),} \mathrm{39G} \mathrm{(45} \mathrm{c),} 55$ (45 c), 90 (45 a), 88 (46 a), $110(46.5 \mathrm{a}), 20(46.5 \mathrm{a}), 4(48 \mathrm{a}), 32$ $(48.5 \mathrm{c}), 59(49 \mathrm{c}), 2(51 \mathrm{a}) .89(51.5 \mathrm{a}), 111(111(51.5 \mathrm{c}), 104(55), 73(55 \mathrm{c}), 41(60 \mathrm{r}), 65(64$ a). 66 (65 c). 24 (66 a). 56 (68 a), 69 (69 a), 102 (81 r), 98 (85 a), $34(85$ a), 95 (90.5 a), 2G (93 c).

+ Quinqueloculina polygona d'Orbigny: 79 (27 r), 72 (25 r), 45 (27 a), 5 I (29 a), 18 (30 c), 22 (32 c). 61 (35 c). 3 (36 a). 43 (37 a), 31 (38 a). 44 (38 a), 19A (38 a). 52 (39 a), 119 (41.5 r), 19G (42 r). 86 (42 a). 5 (44 r). 55 (45 a). 35 (45 a). 20 (46.5 a). 32 (48 a). 59 (49 r). 65 (64 c), $96 \mathrm{~A}(86 \mathrm{c})$.

+ Rectobolivina advena (Cushman): 3 (36 r). 70 (40 r), 86 (42 a), 55 (45 r). 20 (46.5 c), 104 (55 r), 103 (63 c). 96A (86 r). 101 (120 r). 114A (132 c).

Reophax bernudezi Hofker: 60G (95 r).

+ Reophax bilocularis Flint: $22(240 \mathrm{c}) .36(400 \mathrm{c})$.

+ Reophax compressus Goës: 34 (85 c), 95 (90.5 c), 57 (94 r). $95 \mathrm{G}$ (95.5 r), 37 (121 c).

+ Reophax curtus Cushman: 96 (207 c), 22 (240 a), 113 (254 a), 36 (400 a).

Reophax dentaliniformis Brady: 45 (27 r). 55 (45 c).

+ Reophax guttifer Brady: 87 (33.5 c).

+ Reophax hispidulus Cushman: $36(400 \mathrm{c})$.

+ Reophax petrosus Mikhalewich: 87 (33.5 r). 91 (37.3 c). 30 (41 r). 90 (45 c). 88 (46 a), 110 (46.5 a). 73 (55 a), 102 ( 81 a).

+ Reophax regularis Höglund: 91 (37.3 c), 22 (240 c), 13 (940 c).

Reophax scorpiurus (Montagu): 102 (81 r). 36 (400 c).

Reussella atlantica Cushman: 27 (25 r), 3 (36 r), 43 (37 c), 52 (39 c), 86 (42 c), 55 (45 a), 20 (46.5 c), $59(49 \mathrm{r}) .2(51 \mathrm{r}), 111(51.5 \mathrm{r}), 58(66 \mathrm{c}), 34(66 \mathrm{c}), 96 \mathrm{~A}(86 \mathrm{r}), 95(90.5 \mathrm{r})$.

Reussella mortenseni Hofker: 101 (120 c). 114A (132 r).

Rhabdammina triangularis Earland: $22(240 \mathrm{a})$.

Rosalina floridensis (Cushman): 87 (33.5 r), 40G (43 c), 5G (44 c), 39G (45 r), 88 (46 r), 110 (46.5 c). 4 (48 a), 89 (5l.5 r). 73 (55 a). 66 (65 a), 58 (66 r). 24 (66 a), 56 (68 a), 69 (69 a), 21 (72 r), 98 (85 a), 103 (85 r), 112 (88.5 a), 57G (90 r), 95 (90.5 a), 2G (93 c), 23 (95 a), $50 \mathrm{G}(96$ r), 101 (120 c). 37 (121 r). 97 (130 a), 114A (132 c), 114B (138 a).

+ Saracenaria ampla Cushman \& Todd: 60G (95 r), 50G (96 r).

+ Saracenaria arenata d'Orbigny: $22(240 \mathrm{c})$.

+ * Saracenaria eleganta nov. spec.: 73 (55 r), 102 (81 c), 98 (85 r), 34 (85 c), $56 \mathrm{G} \mathrm{(86} \mathrm{c),} 112$ (88.5 a). $57 \mathrm{G}(90 \mathrm{r}) .95(90.5 \mathrm{r}) .23(95 \mathrm{c}), 114 \mathrm{C}(105 \mathrm{r}), 81 \mathrm{G}(120 \mathrm{r}), 97(130 \mathrm{c}), 114 \mathrm{~B}(138 \mathrm{r}), 113$ (254 c).

+ Saracenaria palmerae Cushman \& Todd: 112 (88.5 r), 23 (95 c), 95G (95.5 r), 50G (96 a), 101 (120 c). 37 (121 r).

Septigerina floridana (Cushman): 65 (64 c), 66 (65 a), 58 (66 a), 56 (68 a), 21 (72 r), 98 (85 c), 34 
$(85 \mathrm{c}), 96 \mathrm{~A}(86 \mathrm{a}), 112(88.5 \mathrm{c}), 95$ (90.5 a), 23 (95 c), 95G (95.5 c), 37 (121 r), 97 (130 r).

Sigmoilina schlumbergeri (Silvestri): 97 (130 r), 36 (400 a).

Sigmoilina tenuis Czjeck: 13 (940 c).

+ Sigmopyrgo vespertlio (Schlumberger): $83 \mathrm{G}$ (82 r), 98 (85 a), 103G (85 r), $56 \mathrm{G}$ (86 a), $82 \mathrm{G}$ (88 a), $57 \mathrm{G}(98 \mathrm{r}), 95(90.5 \mathrm{a}), 2 \mathrm{G}(93 \mathrm{c}), 23(95 \mathrm{c}), 56 \mathrm{G}(96 \mathrm{c}), 114 \mathrm{C}(105 \mathrm{r}), 81 \mathrm{G}(120 \mathrm{r}), 10 \mathrm{l}(120$ a), $37(121 \mathrm{r}), 97(130 \mathrm{c}), 114 \mathrm{~A}(132 \mathrm{c}), 1 \mathrm{I} 4 \mathrm{~B}(138 \mathrm{c})$.

Siphonina bradyana Cushman: 45 (27 r), 44 (38 r), 95G (95.5 r).

Siphonina pulchra Cushman: 34 (85 c).

Sphaerogypsina globulus (Reuss): 88 (46 r), 111 (51.5 r), 58 (66 r), 96A (86 r), 95 (90.5 r), 114C (105 r). 97 (130 r), 114A (132 r).

Sphaeroidina bulloides d'Orbigny: 101 (120 a), 37 (121 a), 97 (130 a), 114A (132 c), 114B (138 a), 22 (240 a), 36 (400 a), 13 (940 a).

Spiroloculina angulosa (Terquem): $52(39 \mathrm{r})$.

Spiroloculina arenata Cushman: 34 (85 r).

Spiroloculina caduca Cushman: 54 (38 r), $112 \mathrm{C} \mathrm{(39} \mathrm{r),} 90$ (45 r).

Spiroloculina communis Cushman \& Todd: 45 (27 r), 5 I (29 r), 31 (38 r), 19A (38 r), 52 (39 r), $112 \mathrm{C}(39 \mathrm{r}), 30(41 \mathrm{r}), 55(45 \mathrm{r}), 20(46.5 \mathrm{r}), 32(48.5 \mathrm{r}), 59(49 \mathrm{r}), 111(51.5 \mathrm{r}), 24$ (66 r), 69 (69 r).

Spiroloculina dentata Cushman \& Todd: 88 (46 r), 32 (48.5 r).

Spiroloculina depressa Cushman \& Todd: 31 (38 r), 54 (38 r).

Spiroloculina venusta Cushman: 30 (41 r), 95G (95.5 r).

+ Sporadotrema mesentericum (Carter): 56G (86 r), 57G (90 r), 102G (90 c), 60G (95 c), 52G (96 r), $50 \mathrm{G}(96 \mathrm{a})$.

+ Stainforthia exilis (Brady): 13 (940 a).

Textularia agglutinans d'Orbigny: 45 (27 c), 51 (29 a), 18 (30 r), 80 (35.5 c), 3 (36 a), 43 (37 a), 31 (38 a), 44 (38 a), 19A (38 a), 52 (39 a), 70 (40 c), 55 (45 a), 20 (46.5 a), 4 (48 c), 65 (64 r).

Textularia albatrossi Cushman: 114A (132 r).

Textularia conica d'Orbigny: 65 (64 r), 66 (65 a), 58 (66 a), 56 (68 c), 37 (121 r).

Textularia cuneiformis d'Orbigny: 57 (95 a), 23 (95 r).

Texıluaria mexicana Cushman: 96 (207 a), 22 (240 a), 36 (400 c).

Textulariella barrettii (Jones \& Parker): $110(46.5$ r), 111 (51.5 c), 65 (64 c), 66 (65 r), 24 (66 a), 56 $(68 \mathrm{r}), 69(69 \mathrm{a}), 21$ (72 c), 62G (76 c), 105G (77.6 r), 83G (83 a), 98 (85 a), 103G (85 r), $34(85$ a, A+B), 96A ( 86 a), 82G (88 c), 57G (90 a, A + B), $102 \mathrm{G}(90 \mathrm{a}, \mathrm{A}+\mathrm{B}), 95(90.5 \mathrm{a}, \mathrm{A}+\mathrm{B}), 2 \mathrm{G}$ (93 a), 57 (94 a), 60G (95 a), 23 (95 a), 59G (95.5 a), 114C (105 a A+B), 81G (120 a), 37 (121 a), 97 (130 a), 114A (132 a), 101A (132 c, A+B), 114B (138 a), $113(254 \mathrm{c}) \cdot(\mathrm{A}+\mathrm{B}=$ A-generation and B-generation are both present.)

Trifarina pauciporata Hofker: 34 (85 c), 114A (132 c).

Triloculina tricarinata d'Orbigny: 36 (400 r).

Triloculina trigonula d’Orbigny: 61 (35 r), 44 (38 r).

Tritaxia siphonifera (Cushman): $36(400 \mathrm{r}), 48 \mathrm{G}(500 \mathrm{r}), 13(940 \mathrm{r})$.

Tritaxilina yassicaensis Bermúdez: 23 (95 r), 114C (105 r), 37 (121 a), 97 (130 c).

Trochammina globigeriniformis (Parker \& Jones): 22 (240 r), 36 (400 c), 13 (940 c).

Trochamminella bullata Höglund: $22(240 \mathrm{r})$.

Vaginulina advena Cushman: 57G (90 r), 2G (93 r), 57 (94 r), 60G (95 r).

Vaginulina bermudensis Cushman: 50G (96 r).

Valvopavonina atlantica (Cushman): 43 (37 r), 55 (45 r), 57 (94 r), 60G (95 r).

Valvotextularia candeiana (d'Orbigny): 79 (27 r), 51 (29 a), 67 (30 c), 87 (33.5 c), 80 (35.5 c), 3 (36 c), 43 (37 c), 31 (38 a), 44 (38 r), 54 (38 a), 52 (39 c), 70 (40 r), 119 (41.5 r), 5G (44 r), 55 (45 a), 90 (45 r), 88 (46 c), $110(46.5 \mathrm{c}), 20$ (46.5 a), 4 (48 c), 59 (49 r), 2 (51 a), 111 (51.5 c), 65 (64 c), $66(65 \mathrm{c}), 24(66 \mathrm{r}), 56(68 \mathrm{c}), 69(69 \mathrm{c})$.

Virgulina compressa (Bailey): 114A (132 r), 22 (240 c), 113 (254 r), 36 (499 a).

Virgulina mexicana Cushman: 13 (940 a).

Virgulina pontoni Cushman: 61 (35 a), 52 (39 c), 86 (42 a).

Virgulinopsis cubana (Bermúdez): 86 (42 c). 
Whereas on the Saba Bank light penetrates the water to a depth of up to 70 $\mathrm{m}$, Secchi disc investigations (Eisma, 1967: 22) showed that on the Surinam shelf light penetration is less: the light does not reach the sea floor where the depth is more than $25 \mathrm{~m}$. Consequently those species of Foraminifera, which live symbiotic with zooxanthellae, do not thrive here. This is why Asterigerina carinata, and species of Amphistegina, Articulina, Archaias, Puteolina, and Orbitolites, which are common at the Saba Bank, do not occur on the Surinam shelf. On the edge of the shelf, at a depth of 80-100 m, large numbers were found of Amphistegina gibbosa in eroded condition; it points to sub-fossil or Pleistocene age.

Since temperature is one of the main factors determining the composition of a foraminiferal fauna (see Hofker, 1972: 92), and since there is a manifest temperature-depth relation, it is not surprising that the very wide, gradually dropping off shelf shows a distinct foraminiferal zonation parallel to the coast. Eponides antillarum is found all over the shelf, but the form of its test and the number of chambers gradually change with increasing depth; E. campester, $E$. regularis and E. repandus are found especially between 80 and $200 \mathrm{~m}$ (fig. 4), while $E$. lateralis, a species living attached to shells, algae and hydroids, is mainly found between 10 and $50 \mathrm{~m}$ (fig. 5). Frondicularia sagittula occurs at 80-200 m, often abundantly (fig. 5). Species of Lenticulina are typical for deeper water, but L. lowmanni occurs in shallower water as well. Asterorotalia rolshauseni lives in a broad zone at a depth of 20-40 m (fig. 6). Marginulina planata is found at $60-200 \mathrm{~m}$, whereas $M$. subaculeata occurs at about $130 \mathrm{~m}$ and $M$. glabrata at $300-400 \mathrm{~m}$ only (fig. 7). Virgulina Rephaxssa is restricted to depths of over $200 \mathrm{~m}$, whereas $V$. pontoni occurs at $20-40 \mathrm{~m}$ (fig. 6). Species of Amphicoryna ( $A$. rugosa) are normally found in deep water, whereas $A$. catesbyi lives at depths from 40 to $60 \mathrm{~m}$ (fig. 6).

All species mentioned above are free-living. The distribution of sessile species is mainly restricted to shell or gravel bottoms. Planorbulina caribbeana is found all over the shelf at a depth of 30-130 m, but in deeper water, 80-200 $\mathrm{m}$, on the western part (fig. 3); similarly, Biarritzina was found abundant on the eastern part of the shelf at $30-130 \mathrm{~m}$, while on the western part it occurs at 80-200 $\mathrm{m}$ (fig. 3). Sporadotrema mesentericum and Homotrema rubrum are mainly concentrated at the deeper localities of the western part of the shelf, and the two species of Carpenteria at the deeper stations further east (fig. 3).

Another factor controlling the distribution of Foraminifera is the sediment on the sea floor. On the Saba Bank it consists mainly of organic calcareous material; so it is obvious that a species like Ammobaculites americanus, which 
builds its tests from quartz grains, is not found there, while the species is common in samples from the Surinam shelf, where a considerable part of the sediment consists of rounded quartz grains. Near the coast a thicker layer of Amazonian mud (see Eisma \& Van Bennekom, 1971: 29) is found, in which Ammonia tepida, Eponides lateralis, Elphidium galvestonense, Flintina bradya$n a$ and Hanzawaia concentrica, all mud-dwellers, are typical. In sandy places we find Liebusella arenosa and L. eleganta, the former with a test consisting of quartz sand only, the latter with additional irregular calcareous materiäl. In the calcareous area west of Saint Croix, Saba Bank and west of Barbados, Liebusella soldanii, L. intermedia and L. polyphragma occur with tests agglutinated with calcareous material only.

The following list illustrates the preference of some species for certain sediments as indicated by the number of times found on a particular sediment.

Ammobaculites americanus - clay with sand $(1 \times)$, sand $(2 \times)$, sandy mud $(1 \times)$, mud $(6 \times)$.

Asterorotalia rolshauseni - clay or mud $(14 \times)$, sand $(4 \times)$, a typical muddwelling species.

Rosalina floridensis - coarse sand $(6 \times)$, sand $(3 \times)$, sandy mud $(12 \times)$, mud $(3 \times)$, this species clearly prefers sand.

Flintina bradyana - mud $(7 \times)$, clay $(3 \times)$, coarse sand $(4 \times)$.

Hanzawaia concentrica - mud $(4 \times)$, clay $(4 \times)$, muddy sand $(10 \times)$, coarse sand $(3 \times)$, the species shows a preference for mud and sand.

Liebusella eleganta - mud $(2 \times)$, muddy sand $(6 \times)$, coarse sand $(3 \times)$, the species avoids mud and pure sand.

Quinqueloculina horrida - mud $(2 \times)$, muddy sand $(8 \times)$, sand $(3 \times)$, coarse sand $(3 \times)$, an agglutinated species of sandy sediments.

Textularia agglutinans - mud $(1 \times)$, sandy mud $(2 \times)$, sandy clay $(3 \times)$, sand $(3 \times)$, coarse sand $(5 \times)$, an agglutinated species of sandy sediments.

Liebusella arenosa - mud $(4 \times)$, clay $(3 \times)$, sandy mud $(8 \times)$, sand $(17 \times)$, coarse sand $(12 \times)$, an agglutinated species of sandy sediments.

Frondicularia sagittula - mud $(3 \times)$, muddy sand $(7 \times)$, coarse sand $(4 \times)$, the species shows a preference for sandy sediments.

The calcareous part of the sediment on the Surinam shelf partly consists of subfossil and fossil mollusc shells and fragments of foraminiferal tests. These particles are coated with or wholly permeated by the same reddish ferrugineous material as is found coating the quartz grains. The tests of miliolids in particular are coated, whereas those of Amphistegina and Heterostegina are not. Some tests of Heterostegina do not show any signs of erosion and thus may point to recent occurrence. 
It is remarkable that several species which are found on both the Saba Bank and the Surinam shelf occur at distinctly different depths in these regions. The following list gives an impression of these differences.

Bigenerina irregularis - Saba Bank, 70-340 m; Surinam shelf, 27-94 m.

Biarritzina proteiformis - Saba Bank, 235-340 m; Surinam shelf, 33,5$132 \mathrm{~m}$.

Carpenteria monticularis - Saba Bank, 125-410 m; Surinam shelf, 76-96 $\mathrm{m}$.

Rosalina floridensis - Saba Bank, 74-340 m; Surinam shelf, 33,5-138 m.

Septigerina floridana - Saba Bank, 70-340 m; Surinam shelf, 64-140 m.

Textulariella barrettii - Saba Bank, 235-850 m; Surinam shelf, 46,5-254 m.

Reophax species - All species found in deeper water bij Cushman than by me on the Surinam shelf.

These differences are undoubtedly due to the lower water temperatures on the Surinam shelf than on the Saba Bank at the same depth (see Introduction).

Another phenomenon has to be dealt with here. In many species occurring in both the shallow parts of the shelf and at localities over $80 \mathrm{~m}$, I found that the populations in the shallow water consisted mainly of megalospheric specimens, while those in the deeper places for the greater part consisted of microspheric specimens. This was observed in Liebusella arenosa, L. eleganta, Eponides antillarum, E. lateralis, Sigmopyrgo vespertilio and Textulariella barrettii. A similar case has been described by Christiansen (1965) who found that in the Gulf of Naples Globigerina ruber lives at $250 \mathrm{~m}$ deep in its microspheric generation, buried in the mud; the megalospheric specimens are found floating at $25-50 \mathrm{~m}$ depth. Since it is known that in this species the microspheric generation gives rise to the plasmodiospores which form the megalospheric population, the connection between the two in this case is easily understood: the plasmodiospores rise to form the floating generation. We do not yet understand the connection between the populations of Liebusella and the other benthic species, as in these cases the two generations are not only separated from each other by a vertical distance of some $60-80 \mathrm{~m}$, but also by a horizontal distance of at least $94 \mathrm{~km}$. Since there is a strong upwelling from the edge of the shelf towards the coast, the young specimens of the megalospheric generation may be transported to those places where they are found without the microspheric specimens; the latter are in their turn formed by microspores by the megalospheric generation. We also know that on the sea-floor of the 
shelf water currents exist in different directions, often north and strong enough to transport fine sand over the sea-floor (Eisma, 1967: 24). In this way the microspheric embryos may be transported to the deeper localities (where they have been found).

\section{SYSTEMATIC PART}

Genus Reophax Montfort, 1808

Consisting of a series of chambers joined end to end in a single straight or slightly curved line; next chamber attached to the former one at the place where the protruding neck of the former chamber begins. Test wall consisting of a single layer of agglutinated material. The type-species is Reophax scorpiurus Montfort (see Hofker, 1972: 37).

\section{Reophax bilocularis Flint}

(pl. 1 fig. 9)

Reophax bilocularis Flint, 1897: 273, pl. 1 fig. 2: Cushman, 1920: pl. 3 figs. 3, 4: Hofker, 1972: 38, pl. 9 figs. 3, 4.

Test with 2-3 chambers; last-formed chamber large and pyriform; wall consisting of a single layer of mostly small planktonic Foraminifera.

Found on the slope of the shelf at 240 and $400 \mathrm{~m}$; elsewhere mainly known from deeper water, 800-1300 m (Hofker, 1972: 32).

\section{Reophax compressus Goës}

(pl. 1 fig. 10)

Reophax compressus Goës, 1894: 27, pl. 6 fig. 203-210; Hofker, 1969: 17, figs. 10, 14; 1972: 39 , pl. 9 figs. 5-8.

Test compressed, transverse section oval, last-formed chamber compressed pyriform, with oval aperture on the short neck. Wall consisting of one layer of irregularly placed sand grains of quite different sizes and forms.

At $200-800 \mathrm{~m}$ in the Caribbean Sea, on the slope of the Guyana shelf at 85-121 m, not very common. 


\section{Reophax hispidulus Cushman}

(pl. I figs. 1, 2)

Reophax hispidulus Cushman, 1920: 24, pl. 5 fig. 7.

Cushman's description reads: "Test elongate, composed of pyriform, flasklike chambers, widest at the broadly rounded, somewhat truncate base, apertural end extended, gradually tapering to a slender cylindrical neck; wall composed of fine amorphous material with a large amount of fine sponge spicules, for the most part irregularly arranged, but toward the base of the chamber extending directly backward, especially about the periphery; aperture a small circular opening at the end of the long slender neck; color light gray. Length 3 mm or more."

The species seems to be rather rare; Cushman found it off the west coast of the United States, at $873 \mathrm{~m}$ depth; I found several specimens at St. 36, in 400 m depth.

Remark. It is somewhat uncertain whether this species belongs to Reophax or to Hormosina (see Hofker, 1972: 64, pl. 19 figs. 5-7).

\section{Reophax regularis Höglund}

(pl. 1 figs. 5, 8)

Reophax dentaliniformis Goës (not Brady), 1894: 25, figs. 172-175.

Reophax regularis (Höglund, 1947: 86, fig. 53 pl. 9 figs. 11, 12, pl. 26 figs. 37-43, pl. 27 figs. 2427.

Test elongate, consisting of 5-7 chambers in a straight or slightly curved row. Last-formed chambers longer than broad; last chamber pyriform with rounded aperture; sutures depressed. The walls are agglutinated with somewhat equal quartz grains which are mostly hyaline; walls at the outside nearly smooth.

This species was found on the shelf and its slope (depth 37-940 m), never common.

\section{Reophax guttifer Brady}

(pl. 1 gigs. 6,7)

Reophax guttifer Brady, 1881: 49; 1884: 295, pl. 31 figs. 10-15; Cushman: 1920, pl. 3 fig. 7.

Test straight, composed of 6-7 chambers; chambers pyriform, tapering gradually, with distinct broadest part near the base; sutures distinctly impres- 
sed. Walls agglutinated with irregular sand grains which often protrude at the surface.

Found commonly at station 87 , at $32.5 \mathrm{~m}$ depth. Cushman mentioned it from much deeper water.

\section{Reophax curtus Cushman}

(pl. 1 figs. 3, 4)

Reophax scorpiurus (not Montfort), Goës, 1894: 94, pl. 5 figs. 160-163.

Reophax curtus Cushman, 1920: 8, pl. 2 figs. $2,3$.

Reophax subfusiformis Earland, 1933: 74, pl. 2 figs. 16-19; Höglund, 1947: 82, pl. 9 figs. 1-4; pl. 26 figs. $1-26$; pl. 27 figs. $1-19$; textfigs. 43-50.

Test mostly curved, consisting of 3-5 chambers which are pyriform, the earlier chambers strongly overlapped by the later ones; sutures impressed. Last formed chamber ending in a short apertural neck; wall agglutinated with irregular flat sand grains of different sizes. Last-formed chamber forming a considerable part of the test, especially in tests with few chambers.

This species was found on the slope, at depths of $207-400 \mathrm{~m}$, commonly to abundantly.

\section{Reophax petrosus Mikhalewich}

$$
\text { (pl. } 1 \text { figs. 11, 12) }
$$

Reophax petrosus Mikhalewich, 177: 5, figs. 1, 2.

Test consisting of 3-5 chambers, rapidly increasing in size, last-formed chamber often forming half of the test. Wall agglutinated with large particles of shells and smaller sand grains, the latter often of a black colour. In some rare cases benthic Foraminifera are added. The large shell particles cause a very irregular and rough structure of the test wall. Aperture an irregular opening at the pointed end of the last-formed chamber, in between the agglutination. Length of tests mostly slightly over $1 \mathrm{~mm}$.

This species was described by Mikhalewich from the west coast of Africa, where it occurred at depths of $22-155 \mathrm{~m}$; on the Guyana shelf I found it, often abundantly, at depths of $34-81 \mathrm{~m}$.

Genus Ammobaculites Cushman, 1910

Tests compressed, more or less, consisting of a planispiral series of chambers, uncoiling in the adult. Interior of the chambers simple; walls strongly 
agglutinated of grains in several layers, but layers not distinct. Aperture terminal and rounded (Loeblich \& Tappan, 1964: 239). Type-species is Spirolina agglutinans (d'Orbigny)

\section{Ammobaculites agglutinans (d'Orbigny)}

(pl. 1 figs. 15, 16)

Test beginning with a close-coiled planispiral set of chambers, succeeded by a short series of $4-5$ chambers in a straight line. Sutures between the chambers slightly impressed. Coiled part somewhat compressed, uncoiled part rounded in transverse section. Walls coarsely agglutinated with quartz grains with little colourless cement; colour greyish. Aperture a rounded opening at the end of the test. Found on the slope of the Surinam shelf at 400 to $940 \mathrm{~m}$ deep.

\section{Ammobaculites americanus Cushman}

(pl. I figs. 13, 14, 17)

Haplophragmium fontinense Brady (not Terquem), 1884: 305, pl. 34 figs. 1-4.

Ammobaculites americanus Cushman, 1910: 117, figs. 184, 185; 1920: 64, pl. 12 figs. 6, 7.

Test planospiral, later with few rectilinear chambers, much compressed, sutures slightly impressed. Wall with many irregularly placed, relatively large and flat quartz grains, strongly agglutinated by means of grayisch cement. Septa also agglutinated. In the coiled part the apertures are openings near the bases of the apertural face, in the rectilinear part they are allongate slits at the very end of the chamber, median.

Tests of the shallower stations rather small, coiled part with a diameter of about $0.25 \mathrm{~mm}$; tests from deeper water much stouter, coiled part with a diameter of $0.6-0.8 \mathrm{~mm}$. Found, often commonly, at depths of $53-940 \mathrm{~m}$.

\section{Genus Martinottiella Cushman, 1933}

Tests elongate, cylindrical, early chambers trochospiral with 4-5 chambers in a whorl, progressively reduced to triserial, biserial, uniserial. Walls finely agglutinated. Aperture terminal, an elongate slit; dent formed by the end of a toothplate. Type-species Clavulina communis d'Orbigny. 
Martinottiella pallida (Cushman)

Clavulina communis d'Orbigny, var. pallida Cushman, 1927: 138, pl. 2 fig. 1. Listerella pallida (Cushman), Cushman, 1937: pl. 16 figs. 37-39.

Test slender, early portion fusiform, mostly slightly broader than the rest of the test; in microspheric specimens 4-5 initial chambers, followed by a set of three and a set of two chambers in a whorl, after which the uniserial chambers follow. The uniserial chambers are overlapping each former chamber, resulting in a more proximal broader part of the outer chamber wall. Many specimens have the last-formed chambers narrower than the former ones, resulting in a pointed apical end. Aperture often on a distinct slender neck, mostly with thickened border; this neck consists of a very thin outer layer of fine calcareous grains and a thicker inner layer of pseudochitinous matter, a continuation of the inner pseudochitinous layer of the wall. The walls consist of very fine grains of a hyaline calcite with some larger grains of the same hyaline structure in between. Colour whitish. Length up to $2.5 \mathrm{~mm}$, thickness 0.02 $\mathrm{mm}$.

The species was found commonly to abundantly on the slope at depths of 400 and $940 \mathrm{~m}$; in a dissected specimen rests of protoplasm showed that it was alive at locality 36 , depth $400 \mathrm{~m}$. So far this species had exclusively been reported (Cushman, 1937: 148) from the Pacific coast of the American continent.

Genus Liebusella Cushman, 1933

Species with elongate tests with the broadest end near the aperture, consisting of chambers in 3-4-serial arrangement at the initial end, followed by a set of uniserial chambers, tapering gradually towards the apertural end. Wall of a next chamber partly overlapping the wall of a former chamber. Chambers of the initial part have simple median areal foramina; last-formed chambers have complicated apertural openings. Radially placed internal partitions emerge from the roofs of the chambers into their lumina. Type-species is $\mathrm{Li}$ tuola soldanii Parker \& Jones.

The genus is found mainly in the Caribbean Sea and the Surinam shelf in the Recent. Six species are known here:

Liebusella soldanii (Parker \& Jones). Thick set tests, sutures distinct but shallow, aperture complex. Wall structure formed by scattered large calcareous grains, initially protruding at the surface, in fine calcareous cement. Colour pale yellowish. At depths of 200-600 m; slope of Saba Bank, vicinity of 
Cuba, W of Barbados (Hofker 1969: 37, figs. 96-107).

Liebusella flintiana (Cushman). Test formed by means of irregularly rounded quartz grains and little ferrugineous cement; colour light brown. Tests small, aperture simple but with tooth, irregular secondary septa in the later chambers. At depths of 100-500 m, slope of Saba Bank, Surinam, westcoast of Africa, North Atlantic (Hofker, 1969: 41, figs. 108-112).

Liebusella intermedia (Van den Broeck). Tests slender with smooth surface and indistinct sutures, consisting of very fine white calcareous grains with some scattered black grains; colour nearly white. At depths of $800 \mathrm{~m}$ and more, northern part of Caribbean Sea (around Cuba, W of St. Croix). (Hofker, 1956: 39 pl. 3 figs. 8-31).

Liebusella polyphragma (Goës). Tests built with fine grey mud throughout; thick set, large, sutures distinct, frayed; aperture complex; colour greyish white. At depths of 190-350 m, NW slope of Saba Bank. (Hofker, 1980: 41 fig. 11.)

Liebusella arenosa nov. spec. Test built with mainly distinct quartz grains, cemented together with light-coloured fine calcareous matter; colour grey to greyish brown. Tests thick-set, sutures often nearly invisible, aperture complex. Coast of Surinam, at depths of $40-150 \mathrm{~m}$. (Hofker, this paper, pl. 2 figs. 7-11.)

Liebusella eleganta nov. spec. Test consisting of scattered irregular calcareous grains in fine muddy, calcareous cement, grains of quartz or of calcareous matter of a grey colour. Tests small, often slightly curved, sutures distinct and depressed, aperture complex. At depths from 55 to $85 \mathrm{~m}$, coastal water of Surinam. (Hofker, this paper, pl. 2 figs. 12-16.)

\section{Liebusella arenosa nov. spec.}

(pl. 2 figs. 7-11)

Tests elongate, in the megalospheric generations thick-set with about 5 chambers in the uniserial part and one or two sets of 3-4 chambers in the initial part; sutures very little impressed and often nearly invisible; chambers slightly tapering towards the last-formed chamber which ends in a short neck with the complex aperture. Surface with close-set but distinct sand grains which are hyaline and smoothly finished at the outside, embedded in lightgrey cement. In the microspheric generation, which is found only in the deeper localities, tests much larger; whereas in the megalospheric generation tests have a length up to $3 \mathrm{~mm}$, in the microspheric generation they reach lengths up to $7 \mathrm{~mm}$, with 8 uniserial chambers. Inner structure of chambers with radially placed partitions, leaving a central hollow free. Colour of tests brownish grey. Found on the Guyana Shelf at depths of 40-150 m. 
Liebusella eleganta nov. spec.

(pl. 2 figs. $12-16$ )

Tests elongate, often slightly curved, slender in the megalospheric specimens, with about 5 chambers in the uniserial part and one set of 3-4 chambers in the initial part, sutures distinct, chambers strongly overlapping former chambers, tapering towards the end-chamber, last-formed chamber pyriform with distinct short neck on which the complex aperture is found. Surface with scattered grains (quartz or calcareous), which protrude at the surface, embedded in grey cement. Microspheric specimens larger, with less slender tests. Walls thin, inner structure with radial partitions. Megalospheric specimens 1-2 $\mathrm{mm}$ long, microspheric specimens up to $6 \mathrm{~mm}$. Colour of tests light grey.

Found on the Guyana Shelf at depths of $35-85 \mathrm{~m}$.

Genus Nodobacularia Rhumbler, 1895.

Tests attached with the flat side of the chambers, beginning with a short miliodid set of chambers, followed by many chambers irregularly creeping on the surface of the substrate, often forming branches. The free side of the chambers is often ornamented by fine costae, knobs, in one species sand grains are incorporated in the ornamentation. Walls calcareous and porcellaneous; the initial miliolid chambers have very thin walls and can be seen only in a clarifyer. Aperture in the end of the last formed chamber; each next chamber is attached to the short neck of the former chamber. It may be that Webbina d'Orbigny, 1839 is identical with Nodobacularia, but till now no specimens of Webbina were described in which the miliolid initial chambers occurred, so that we do not know whether or not Nodobacularia and Webbina are identical (see Hofker, 1976: 157.)

Nodobacularia pustulosa nov. spec.

(pl. 3 figs. 1,2)

Test attached to shells, consisting of three or four coiled chambers, followed by several pyriform chambers with flat, thin-walled attached side and an opposite convex wall. Chamber walls at the free side ornamented by globular calcareous pustules which are arranged in rows or more irregularly densely placed. Length of whole test up to $1.5 \mathrm{~mm}$, of last-formed pyrifom chamber $0.35 \mathrm{~mm}$. Test wall porcellaneous.

Specimens were found in three localities, at depths of 48.5-84 m. 
Genus Sigmopyrgo nov. gen.

Schlumberger (1891: 174, textfigs. 20-22, pl. 10 figs. 74-76) described the species Biloculina vespertilio found by him in the Gulf of Biscay. He showed that this species in the megalospheric generation has the structure of Biloculina d'Orbigny, 1826 (now Pyrgo Defrance, 1824), but that the microspheric generation does not have the quinqueloculine initial structure but begins quinqueloculine, whereas this arrangement is followed by the typical structure found in Sigmoilina; this arrangement of the chambers is followed by two chambers directed perpendicular to the axis of coiling of the initial part, and these chambers are succeeded by several biloculine chambers with very thick walls, coiling on an axis perpendicular to the initial axis. In Pyrgo the microspheric generation shows a succession of quinqueloculine, triloculine and biloculine chambers.

So the species called Biloculina vespertilio by Schlumberger is the type-species of a new genus, Sigmopyrgo Hofker, with a characteristic biloculine arrangement of the chambers in the megalospheric generation, whereas in the microspheric generation the arrangement of the chambers is subsequently quinqueloculine, sigmoiline and biloculine coiling.

Note. I described the new genus Pseudopyrgo (1976: 110); however, this name has already been used for a wholly different form (Biloculina milletti Cushman) by Rasheed (1971). So this genus must be renamed; I propose the genus-name Nummulopyrgo, with the type-species Biloculina globulus Bornemann.

Sigmopyrgo vespertilio (Schlumberger) comb. nov.

(fig. 8, pl. 4 figs. 1-6)

Biloculina vespertilio Schlumberger, 1891 : 174, figs. $20-22$, pl. 10 figs. $74-76$.

Pyrgo vespertilio (Schlumberger), Andersen, 1961: 40, pl. 8 fig. 5.

Tests nearly globular, suture between the two last formed chambers partly indistinct by irregular calcareous buds. End of last formed chamber forming the aperture, which is brace-like with irregularly thickened borders, more open in the specimens of the megalospheric generation with smaller tests than in the microspheric generation with larger tests (diameters up to $1,5 \mathrm{~mm}$ ).

In the B-generation the tests begin with a small proloculus, followed by 5 chambers arranged in quinqueloculine succession; from the chambers 3 and 5 two sets of chambers start forming two short spirals embracing one half of the initial tests, seen in transverse section. From these spirals, identical with those found in Sigmoilina, two elongate chambers are formed, growing in a plane 
perpendicular to the direction of coiling of the former chambers and embracing the former chambers. These two chambers are followed by much broader chambers, the bilocular chambers of the adult test, characterized by very thick outer walls; their coiling axis is perpendicular to the primary axis also.

Most of the specimens found belong to the megalospheric generation which is wholly bilocular.

Microspheric specimens are very rare, found in deep water only; the megalospheric specimens have a diameter of about 0.75 to $1 \mathrm{~mm}$.

This species appears to have been mentioned from the Caribbean Sea only by Andersen; Schlumberger described it from the Gulf of Biscay, and Cushman mentioned it from the Philippines (1921: 472). It was found, often abundantly, on the slope of the shelf at depths of $85-940 \mathrm{~m}$.

\section{Genus Pyrgoides Hofker, 1976}

Characterized by a succession of triloculine and biloculine arrangement of the chambers in the microspheric generation, whereas in the megalospheric generation the arrangement of initial chambers may be triloculine also. Typespecies is Biloculina ringens Lamarck var. denticulata Brady.

\section{Pyrgoides nasutus (Cushman)}

(fig. 8 , pl. 3 figs. $3-5$ )

Pyrgo nasuta Cushman, 1935: 7, pl. 3 figs. 1-4; Phleger \& Parker, 1951: 7, pl. 3 figs. 12-14; Drooger \& Kaasschieter, 1956: 61; Andersen, 1961: 38, pl. 9 figs. 2.

Pyrgo phlegeri Andersen, 1961: 38 pl. 8 fig. 1.

Test compressed with broad flange around the periphery, up to the sides of the apertural nack, slightly to strongly oval in broad view. Aperture found on a distinct neck which is compressed also. Aperture a narrow slit with rounded opening at both ends of the slit, formed by a kind of broad and low dent. Keel or flange in megalospheric specimens serrate, especially at the antapical side; in the slightly stouter microspheric specimens smoothly finished, not serrate. As this characteristic was the main one for Pyrgo phlegeri distinguished by Andersen, it is obvious that both forms belong together in the species $P$. nasuta Cushman; as the initial chambers are triserially arranged in both generations, it is obvious that the species belongs to the genus Pyrgoides Hofker; Andersen mentioned that his Pyrgo phlegeri must be close to P. nasuta; as Pyrgo nasuta Cushman differs from Pyrgoides denticulatus (Brady) in having an aperture with distinct neck and a somewhat pronounced flange, but resembles Pyrgoides denticulatus in the triserial (triloculine) arrangement of the ini- 
tial chambers in both generations, there is no doubt as to $P$. nasuta belonging in the genus Pyrgoides with $P$. denticulata Brady as type-species.

The species occurs, never abundantly, at depths of $41-400 \mathrm{~m}$; it was mentioned by Boltowskoy $(1957,1959)$ from the coast of Brazil.

\section{Genus Quinqueloculina d'Orbigny, 1826}

Tests in both $B$ and $A$ generations (or in all three, $B, A_{1}$ and $A_{2}$ ) quinqueloculine throughout. In some species (as in the type-species) all five chambers are not always visible from the outside, since some of the later chambers are overlapping former chambers. The type-species is Serpula seminula (Linnaeus).

\section{Quinqueloculina polygona d'Orbigny}

$$
\text { (pl. } 3 \text { figs. } 7-10 \text { ) }
$$

Quinqueloculina polygona d'Orbigny, 1839: 198, pl. 12 figs. 21-23: Cushman, 1929: 28, pl. 3 fig. 5; 1932: 25 pl. 6 figs. 5-6; Hofker, 1969: 42, fig. 113; Le Calvez, 1977, 1: 84.

Quinqueloculina compta (not Cushman), Anderson, 1961: 29, pl. 4 figs. 2, 3; Phleger \& Parker, 1951: 7, pl. 3 figs. 16, 17.

Test in the microspheric generation elongate, with apertural neck bent towards the dorsal side of the chamber; last formed chamber here at the aboral side rounded and protruding; several more or less distinct costae at each of the chamber walls, each chamber basically attached to the costae of former chambers. Proloculus small, inner diameter being $17 \mu \mathrm{m}$. Test in the commoner megalospheric generation more oval, with the same apertural neck and the same costae per chamber. Here the proloculus with diameter about $58 \mu \mathrm{m}$. Walls with scattered agglutination.

The species differs from Quinqueloculina compta Cushman, which lacks agglutination. Moreover, $Q$. compta as interpreted by Andersen undoubtedly is identical with Quinqueloculina berthelotiana d'Orbigny (Le Calvez, 1974: 49-51).

Found at the Surinam Shelf at depths of $27-86 \mathrm{~m}$.

\section{Quinqueloculina horrida Cushman}

Quinqueloculina horrida Cushman, 1947: 88, pl. 19 fig. 1; Phleger \& Parker, 1951: 7, pl. 3 figs. 18, 19.

Tests small, length never more than $0,5 \mathrm{~mm}$, twice as long as broad. Aperture on a distinct neck without agglutination and with a phialine lip and sim- 
ple small tooth. Surface rough by coarse agglutination consisting mostly of calcareous grains of quite variable sizes, also with incorporated small foraminiferal tests.

It is possible that rare slender specimens form the microspheric generation. The plump forms are megalospheric. The inner structure is quinqueloculine throughout.

This species was found at depths of 45-121 m; Cushman described it from off Florida, depth $120 \mathrm{~m}$; Phleger and Parker mention it down to $200 \mathrm{~m}$.

\section{Genus Flintina Cushman, 1921}

Tests often large and in the end with chambers which are shorter than half a coil, resulting in three chambers in a coil. Aperture large, consisting of one wide open part towards the top of the chamber and a second smaller part near to the basal suture. In the wide part the opening is partly closed by a bifid toothplate, irregular of shape. From the suture where the smaller part of the opening is found, a sharp dent is running upward to the bifid part of the tooth where it fastens to it. In between the dent and the tooth an elongate opening remains. Mostly the tooth protrudes out of the aperture.

Type-species is Miliolina fichteliana Brady (not d'Orbigny).

Flintina bradyana Cushman

$$
\text { (fig. 8, pl. } 4 \text { figs. } 7-10 \text { ) }
$$

Miliolina fichteliana Brady (not d'Orbigny), 1884: 169, pl. 4 fig. 9.

Triloculina fichteliana d'Orbigny, Cushman, 1932: 55, pl. 12 fig. 6.

Flintina bradyana Cushman, 1921: 467, pl. 94 fig. 2; figs. $38-44$.

Flintina lingulata Mikhalewich, 1976: 448, fig. 6.

Test as described for the genus; in the large specimens the proloculus is very large. Tests mostly with longitudinally running striae over the surface of the chambers. Aperture in the smaller specimens oval, in the larger ones keyholelike. The large proloculus is the cause of the triserial arrangement of the chambers.

The species is common at the Surinam Shelf at depths of 39-86 m. Mikhalewich mentioned it from the Atlantic coast of South America.

\section{Genus Glandulina d'Orbigny, 1826}

Tests elongate, circular in section, early chambers arranged biserially, chambers overlapping and increasing in size with growth; sutures flush with 
the surface. Aperture radiate, end-standing, forming a distinct poreless chamberlet and an entosolenian tube. Pores extremely fine. Type-species: Glandulina laevigata d'Orbigny.

Glandulina surinamensis nov. spec.

(pl. 4 figs. $11-18$ )

Glandulina laevigata (not d’Orbigny), Todd \& Brönnimann, 1957: 32, pl. 5 fig. 23.

Tests slender, fusiform, 2-2.5 times longer than broad. The specimens are small, up to about $0.5 \mathrm{~mm}$, but generally about $0.37 \mathrm{~mm}$.

In the microspheric form two or three chambers follow the proloculus which has in general a diameter of $15 \mathrm{~mm}$. These initial chambers are biserially or triserially arranged, just as found in Glandula glans d'Orbigny and $G$. laevigata d'Orbigny by Selli (1947: pl. 3 figs. 11, 12). The initial chambers are succeeded by two or three chambers in uniserial arrangement; the last formed chamber is elongate in most microspheric specimens. The test walls are extremely thin and pierced by densely set very fine pores. The apertures in both generations consist of a kind of chamberlet with radial apertural openings and a thinwalled internal tube opening into the last formed chamber. In the megalospheric generation the proloculus is rather large, with diameter of 50-75 $\mathrm{mm}$. This results in a rounded initial part, whereas in the microspheric form the initial end of the tests is pointed. One specimen was found with the whole test consisting of the proloculus only, with a diameter of $150 \mu \mathrm{m}$. In specimens with a proloculus of $50-75 \mu \mathrm{m}$, it is succeeded by two or three chambers, which are placed uniserially. Several specimens had the apertural chamberlet (which is separated from the main chamber) broken off and only a serrate border remained. As the wall of the chamberlet never shows pores, this part in dry state is distinctly separated from the rest of the test as an hyaline cap.

Glandula surinamensis occurs, often commonly, at depths from 27 to $41 \mathrm{~m}$, and rarely at $51.5 \mathrm{~m}$ and $66 \mathrm{~m}$ on the shelf. This occurrence in shallow water contradicts the appearences of the other species of Glandulina, which are found in much deeper water. Todd \& Brönnimann (1957:8) observed this species at the same depth in the Gulf of Paria, at 0-18 fathoms, common to abundant.

\section{Glandulina torrida Cushman (pl. 5 figs. 2-5)}

Nodosaria laevigata d'Orbigny, Flint, 1897: 303, pl. 55 fig. 3.

Nodosaria (Glandulina) laevigata d'Orbigny var. torrida Cushman, 1923: 65, pl. 12 fig. 10. 
Test in the microspheric generation nearly globular, at the initial end with one or more short spines and in the megalospheric generation fusiform, also with short terminal spine. Tests large for the genus, length of both generations about $1 \mathrm{~mm}$.

Microspheric generation: two or three chambers follow the proloculus which are very small; than 5 chambers follow, the last one forming more than half of the test; megalospheric generation: one large proloculus, followed by one elongate chamber forming $3 / 4$ part of the test. Walls thin, with fine and densely placed pores. In both generations terminal apertural chamberlet exists. The aperture is represented by a stellate structure composed by grooves ending in the middle of the star in tiny openings which form canals through the apertural chamberlet; they build together the internal relatively short entosolenian tube. This tube runs through a round opening of the inner wall of the apertural chamberlet. In the megalospheric generation the stellate aperture is not as well developed as in the microspheric from.

Length of microspheric generation about $1 \mathrm{~mm}$, breadth $0.8 \mathrm{~mm}$; length of megalospheric generation about $1 \mathrm{~mm}$, breadth $0.45 \mathrm{~mm}$.

Cushman found this species in three localities W of Florida, depth 408-860 $\mathrm{m}$. The species was found at St. 13, depth $940 \mathrm{~m}$; obviously it is a deep water form. Flint mentioned it from several stations in the Gulf of Mexico, also from deep water $(249-5011 \mathrm{~m})$.

\section{Genus Dentalina Risso, 1826}

Tests consisting of a single row of tapering chambers; walls with fine pores, with radiate structure and radial aperture in the centre of the top of the endchamber, with all sutures transversely placed on the length of the test, belong to the genus Nodosaria. Tests with similar structure but with the aperture at one side of the test and oblique sutures with the upper part at the same side as where the aperture is found, belong to the genus Dentalina. Both general may have straight tests or curved tests.

\section{Dentalina bradyensis (Dervieux)} (pl. 5 fig. 1)

Nodosaria inornata (d'Orbigny) var. bradyensis Devieux, 1894: 610, pl. 5 figs. 30, 31. Nodosaria communis Brady, 1884: pl. 62 figs. 19, 20, in Barker, 1960: 130.

On the basis of the oblique sutures this species should be accomodated in the genus Dentalina, as Barker already suggested. The test is without any ornamentation, elongate, with depressed oblique sutures. 
As Brady reports this species from the West Indies, it may be assumed that this species is characteristic for this middle American region.

The only specimen came from a depth of $138 \mathrm{~m}$. Brady mentioned it from deeper water (540-744 m). Flint (1897: 310) mentions Nodosaria communis d'Orbigny from the Gulf of Mexico, which may be the same species.

\section{Genus Frondicularia Defrance, 1826}

Tests beginning with a planispiral in the microspheric form, gradually lengthening the chambers and in the end with more and more embracing chambers in the compressed test; in the megalospheric form the large proloculus is succeeded by embracing chambers only. End-chamber with terminal radiate aperture. Walls with radiate microstructure and with very fine pores. The type-species is Frondicularia complanata Defrance.

\section{Frondicularia sagittula Van den Broeck}

(fig. 5, pl. 5 figs. 6-9)

Frondicularia alata d'Orbigny, var. sagittula Van den Broeck, 1876: 113, pl. 2 figs. 12-14.

Frondicularia sagittula Van den Broeck, Cushman, 1923:143, pl. 21 figs. 1, 2; 1943: 25-26, pl. 5 figs. 1-6; pl. 6 figs. 1, 3; Barker, 1960: 138; Hofker, 1969: 58, fig. 153; 1976: 90, fig. 79.

Nodosaria complanata (Defrance), Goës, 1882: pl. 3 figs. 62-64.

Frondicularia alata (not d'Orbigny), Brady, 1884: 552, pl. 65 figs. 20-23; Flint, 1897: 313, pl. 59 fig. 1.

This species shows a strong variation in the general forms of the tests; in some regions, as in Jamaica, triangular specimens with nearly straight margins are dominant, whereas West of Barbados and on the Guyana Shelf specimens with curved and rounded margins are commonest; in deep water, as near $\mathrm{St}$ Croix $(800 \mathrm{~m})$, specimens of both forms occur and remain small. This phenomenon was also noticed in samples from deeper water of the Guyana Shelf, whereas at a depth of $88-96 \mathrm{~m}$ in the latter region the specimens can attain very large dimensions, with a length and breadth of about $6 \mathrm{~mm}$ (see also quoted literature).

As already stated bij. Cushman (1943) the microspheric form has a distinct initial spine in which the chambers following the small proloculus are arranged as in the genus Palmula, whereas in megalospheric specimens with relatively small as well as with larger proloculi, the next chambers are equittant. In the microspheric generation about 9 chambers in Palmula-arrangement are followed by the equittant chambers also.

Noticeable was a specimen which had its distal part broken away and which restored its test till it had the normal form by means of much fewer 
chambers than found in the unbroken part; this phenomenon was previously reported by Pozaryska (1957: 121 figs. 17, 18) from Cretaceous specimens of the "Frondicularia" group.

Frondicularia sagittula is found on the Guyana Shelf along the border of the shelf at depths of $77.6-96 \mathrm{~m}$, where the species is abundant; yet the microspheric specimens remain very rare.

Genus Amphicoryna Schlumberger, 1881

Tests strongly resembling those of Nodosaria, with 2 or more chambers in a single row. End-chamber with a distinct or even long neck, often provided with rings of spines and ending in a crown of radiant openings. Later chambers may be separated from each other by the remains of the neck of the former chamber, or they may overlap these necks; in this case they follow each other directly. Later necks may be broken, closed at the antapical side of the separated chamber and this chamber may than form the proloculus of an $\mathrm{A}_{2}$ individual. The microspheric generation begins with a small elongate chamber succeeded by several chambers arranged as in Vaginulina or in microspheric Frondicularia and was formerly known by another name. After this set of chambers the rectilinear chambers start. So there may be several forms in each species: the microspheric form, the megalospheric form beginning with a small megalospheric proloculus and the form beginning as a Lagena and the form which is the result of this Lagena, the generation with a large proloculus. Type-species is Marginulina falx Jones \& Parker (the microspheric form of Amphicoryna scalaris (Batsch)].

\section{Amphicoryna rugosa d'Orbigny \\ (fig. 6, pl. 6 figs. 1-4)}

Nodosaria rugosa d'Orbigny, 1839: 13, pl. 1 figs. 2, 3.

Amphicoryna rugosa (d'Orbigny), Hofker, 1980: 59, fig. 17 c.

Tests were mostly megalospheric. Only a single specimen of the very rare microspheric form was found at St. 22, depth $240 \mathrm{~m}$; this complete specimen gives proof that the species belongs to Amphicoryna.

The microspheric test consists of a small oval proloculus (length $30 \mu$, breadth $10 \mu$ ), followed by a set of 8 chambers in Vaginulina-like arrangement, as found in the type-species of Amphicoryna (see Hofker, 1932: 110114, figs. 27-29; Buchner, 1940: 404, pl. 1). These chambers with their oblique sutures show one or two longitudinal costae on each side. This group of chambers is succeeded by two Nodosaria-like chambers with many costae 
ending proximally in distinct spines; subsequently there is a third chamber in which the longitudinal costae are broken up into short costae, followed by two nodosarid chambers connected by a neck. The ornamentation of the neck consists of the typical short and often blunt, irregularly placed knobs or short spines. In this specimen the neck of the aperture is present, but the aperture itself is broken off.

In the megalospheric specimens the proloculus is a globular chamber, with a diameter of $90-115 \mu \mathrm{m} ; 3$ to 5 chambers follow without distinct necks in between: the proloculus may have broken costae, but the larger proloculi have already the more evolved irregularly placed spines as ornamentation. Two or three chambers follow with long necks in between. Several specimens of this generation have the last formed neck unbroken; it ends in the characteristic circle of short dents surrounding the rounded aperture. These dents form a crown of tiny costae within the inner wall of the long canal in the neck. When the neck is broken, these costae form a stellar structure around the small opening in the neck, as described by d'Orbigny and figured in his figure 3 . The individual figured by d'Orbigny represents an incomplete megalospheric specimen consisting of 5 chambers without necks.

Remark. Y. le Calvez (1977b: 50) could not find the specimen figured by d'Orbigny in his material collection and consequently regarded this species as invalid (why is not understandable). However, Amphicoryna rugosa (d'Orbigny) is only found in deeper water, and the specimen which he described was rare in his material. Yet Bermúdez (1935: 180) found two specimens in his material from the Bahia de Matanzas, and so this species is known from the type-locality, Cuba. There is no reason to declare this species-name as invalid, as Le Calvez did.

Amphicoryna catesbyi d'Orbigny

(fig. 6, pl. 6 figs. 5-7)

Nodosaria catesbyi d'Orbigny, 1939: 16, pl. 1 figs. 8-10; Cushman, 1930: 28, pl. 3 fig. 4; Cushman \& Parker, 1931: 7, pl. 3 figs. 3, 4; Todd \& Brönnimann, 1957: 31, pl. 5 fig. 4; Le Calvez, 1977, 2: 47,48 , figs. $]-5$.

Test consisting of 2 chambers, rarely of 3 or 4 chambers. The chambers show longitudinal, slightly winged costae, which continue on the neck of the aperture and end there in the typical sharp dents surrounding the apertural opening, a diagnostic character. Length of tests $0.4-0.5 \mathrm{~mm}$; breadth 0.16 $\mathrm{mm}$.

This species was observed at depths of 35-64 m. 
Genus Saracenaria Defrance, 1824

Tests built as in an uncoiled Lenticulina with chambers arranged in a short spiral succeeded by a series of chambers arranged in a straight or slightly curved line, separated by oblique sutures which are seldom impressed. Transverse section of the chambers an isosceles triangle, so that one side of the test is more or less flat; the side where the foramina are found and the aperture is the top of the triangle. Aperture radial. The type-species is Saracenaria italica Defrance.

Saracenaria palmerae Cushman \& Todd

(pl. 6 figs. 13, 14)

Saracenia palmerae Cushman \& Todd, 1945: 30, pl. 5 fig. 1.

Early part close-coiled, apertural face triangular, bulged, one to three chambers in the uncoiled part, coiled part more compressed than the last formed chambers. In the coiling part sutures beaded, in the uncoiled part sutures raised and distinct. Wall in the uncoiled part smooth with very fine, densely placed pores, in the coiled part finely beaded, in later chambers only the ventral parts of the walls with fine knobs. Dorsally with a more or less pronounced keel. Aperture protruding, radiate. Length of tests up to more than $1 \mathrm{~mm}$, often smaller; largest breadth $0.5 \mathrm{~mm}$.

The species was originally described from the Pliocene (Cushman \& Todd speak of Miocene, which was corrected by Blow (1969: 254) to be his zone 19, Pliocene). The occurrence of this species abundantly at depths of $88.5-138 \mathrm{~m}$ suggests that the species is still living in the Recent.

\section{Saracenaria arcuata d'Orbigny}

$$
\text { (pl. } 6 \text { fig. 12) }
$$

Saracenaria arcuata d'Orbigny, 1846: 87, pl. 3 figs. 34-36; Cushman \& Todd, 1945: 31, pl. 5 fig. 4 ? Saracenaria acutiauricularis (Fichtel \& Moll), Flint, 1897: 316, pl. 63 fig. 5; Hofker, 1969: 53, figs. 128-130.

Test small, with inflated apertural face of the last formed chamber, slightly rounded sutures which are smooth with the surface; tests without any ornamentation. Length of test about $0.5 \mathrm{~mm}$. All specimens found at St. 22, depth $240 \mathrm{~m}$ are small without uncoiling chambers. As $S$. acutiauricularis from W. of Trinidad had these later chambers developed, it is uncertain that the species found on the Surinam Shelf belongs to this species. As they are found toge- 
ther with many distinctly recent species of Foraminifera, they are living here. $S$. arcuata was described from the Miocene and Pliocene.

Saracenaria eleganta nov. spec.

(pl. 6 figs. $8-10$ )

Tests small for the genus, length $1-1.7 \mathrm{~mm}$, consisting of a short spiral followed by 3-6 uncoiled chambers, the latter with distinct keels bordering the ventral side. Dorsal side not keeled in the middle. Last formed chamber at the ventral side as high as broad or somewhat higher than broad. Dorsal sutures not depressed, curved, ventral sutures depressed and horizontal. The number of uncoiled chambers less than in $S$. italica Defrance with 7-9 chambers and a much stouter test. $S$. eleganta is more slender with thinner walls. Most characteristic are the distinct keels bordering the ventral side of the tests.

This species was found in many samples from $55 \mathrm{~m}$ to $254 \mathrm{~m}$ depth, abundantly at 85 and $88.5 \mathrm{~m}$.

\section{Saracenaria ampla Cushman \& Todd}

(pl. 6 fig. 11)

Saracenaria arcuata (d'Orbigny) var. ampla Cushman \& Todd, 1945: 31, pl. 5 figs. 5, 6. Saracenaria ampla Cushman \& Todd, Andersen, 1961: 59, pl. 14 fig. 5.

This stout species, length and diameter being equal, $1.5 \mathrm{~mm}$, with few uncoiled chambers, was found rarely at $95 \mathrm{~m}$ and $96 \mathrm{~m}$ depth.

\section{Genus Marginulina d'Orbigny, 1826}

Test elongate, oval in transverse section; specimens with small proloculus planispiral in the initial part, those with large proloculus may lack the spiral. As the apertures of the planispiral chambers are situated at the periphery of the coil, those in the straight part are formed at the same side on which the last formed spiral chamber had its aperture. Apertures radial, those of older chambers closed by the partly overlapping next chamber.

\section{Marginulina tenuis Bornemann}

$$
\text { (pl. } 7 \text { figs. 1, 2) }
$$

\footnotetext{
Marginulina tenuis Bornemann, 1855: 326, pl. 13 fig. 14; Flint, 1897: 315, pl. 61 fig. 2, described as Cristellaria tenuis; Barker, 1960: 140.

Cristellaria tenuis (Bornemann), Brady, 1884: 535, pl. 64 figs. 21-23.
} 
Test relatively small and slender, consisting of a spiral of 8 chambers succeeding the proloculus in the microspheric form (diameter proloculus $15 \mu \mathrm{m}$ ), and of 3 chambers in the megalospheric generation (proloculus diameter about $35 \mu \mathrm{m}$ ). Subsequently about 6 chambers follow which are distinctly compressed and the last formed part of the test with 3-6 chambers which are distinctly inflated with impressed sutures in between; in most tests the latter part is slightly curved towards the ventral side. Foramina of the chambers and aperture of the last-formed chamber near the dorsal side, aperture radiate. Especially in the depressed part of the test at the dorsal and ventral sides a slightly developed carina is present. Walls thick in the compressed part, thinner in the inflated chambers, with very fine and densely placed pores.

Length of tests up to $2 \mathrm{~mm}$, thickness of compressed part $0.08 \mathrm{~mm}$, of the inflated part $0.14 \mathrm{~mm}$, breadth of tests up to $0.2 \mathrm{~mm}$.

The species was found in many specimens at St. 22 (depth $240 \mathrm{~m}$ ) and at St. 36 (depth $400 \mathrm{~m}$ ).

\section{Marginulina glabrata (Cushman)}

(fig. 7 , pl. 7 figs. 3-8)

Cristellaria subaculeata n. sp. var. glabrata Cushman, 1923: 124, pl. 32 fig. 4; pl. 33 figs. 2, 3; pl. 34 fig. 3.

Nodosaria crepidula Fichtel \& Moll var. cassis Goës, 1882: 49, pl. 3 figs. 50, 51.

According to Cushman's description ("especially the greater development of spines on the periphery"), this species is sufficiently characterized. In the material at hand there are specimens which lack the pustules on the sutures, another characteristic emphasized by Cushman, but most of the specimens show them; there are specimens which show these pustules on the side walls of the chambers also, as figured by Cushman. The chambers are much broader than in the preceeding species and besides more inflated, obvious when we observe a specimen from the narrow side.

There are two generations. The megalospheric generation, being the common form, has a large proloculus seen at the ventral side, followed by 4 coiling chambers and 3-5 rectilinear chambers; as this megalospheric proloculus is not entirely enclosed by the coiling chambers, the species must belong to the genus Marginulina. In the microspheríc generation the proloculus is wholly surrounded by $10-12$ coiling chambers. Thus the microspheric generation might be identified as a species of Cristellaria (now Lenticulina) as Cushman did. The spines, when not broken, are extremely long, but there exist specimens without spines (not broken away spines), though they are rare in the material. These specimens lead over to the allied species Marginulina subacu- 
leata (Cushman) (fig. 7; see also Hofker, 1976: 77, fig. 57).

This species was found abundantly at depths of 207 and $254 \mathrm{~m}$.

Marginulina planata Phleger \& Parker

(fig. 7 , pl. 7 fig. 11 , pl. 8 figs. $1-5$ )

Marginulina planata Phleger \& Parker, 1951: 9, pl. 4 figs. 21, 22; pl. 5 figs. 1-3.

Marginulinopsis bradyi (Goës), Barker, 1960: 136, pl. 65 fig. 11.

Marginulina costata (Batsch), Hofker, 1969: 49, fig. 126.

Marginulinopsis densicostata Thalmann, 1937: 241, 348 (type-species of Marginulinopsis).

Marginulinopsis sp., Vaginulinopsis planata (Phleger \& Parker), Andersen, 1961: 65.

This species is very variable; microspheric specimens show a dense but compressed initial spiral of 10-11 coiled chambers, followed by 4-6 compressed, uncoiled chambers; megalospheric specimens are present in two forms: one is compressed throughout, the other ends with more elongate chambers which are more or less rounded in transverse section and have impressed sutures. It is very probable that the last mentioned chambers break off easily and form the proloculus of the $\mathrm{A}_{2}$-generation, as the one figured by Brady (1884, pl. 65 fig. 10). The ornamention consists of longitudinal costae, in broad chambers, about 9 of them at one side, in elongate specimens fewer of them. In the elongate forms the costae remain simple, but in short specimens especially in more initial chambers they end proximally into drops and knobs at the sutures.

Microspheric and megalospheric specimens have their proloculi near or at the ventral side; this is the characteristic of Marginulinopsis. In 1969 I proposed to drop the genus-name Marginulinopsis Silvestri and to include all specimens with coiled initial parts in Marginulina, since in most of the species only the microspheric generation shows the Marginulinopsis characteristic whereas the megalospheric generation shows the initial parts of Marginulina (Hofker, 1969: 45). I identified Marginulina costata (Batsch) in accordance with Brady and Cushman; it does not seem to be the same species as $M$. planata Phleger \& Parker when it is compared with the figures given bij Brady as M. costata. So Phleger \& Parker were right to give the compressed species found in the Caribbean Sea and identical with the specimens found in the Surinam Shelf a new name.

Marginulina anderseni nov. spec.

Vaginulinopsis sp. Andersen, 1961: 65, pl. 15 figs. 12, 13. 
Test small, much compressed with flat parallel sides, consisting of a coiled part and several chambers becoming more uncoiled. Apertural face slightly inflated, aperture radiate. Ornamentation consisting of several indistinct longitudinal costae in each chamber, which costae do not continue in the next chamber, which shows costae also. Several costae are found at the dorsal margin, in their midst a distinct keel. Aperture slightly protruding, radial.

The species strongly points to the genus Planularia Defrance. However, specimens occur with the last formed chambers growing in a straight line, characteristic for Marginulina.

\section{Genus Lenticulina Lamarck, 1804}

Tests planispiral or slightly trochoid, lenticular, biumbonate, periphery angled or keeled, chambers gradually larger in size, generally of greater breadth than height, sutures radial, straight or curved and depressed, flush or elevated, surface may be variously ornamented with thickened, elevated sutures, bosses or sutural nodes; aperture radial at peripheral angle (see Loeblich \& Tappan, 1964: 520). We may add that several species show spines at the periphery.

\section{Lenticulina calcar (Linnaeus)}

(fig. 2, pl. 8 figs. 8, 9)

Nautilus calcar Linnaeus, 1862: 1162, no. 272.

Cristellaria calcar (Linnaeus), Brady, 1884: 55, pl. 70 figs. 7-10.

Robulus calcar (Linnaeus), Andersen, 1961: 48, pl. 11 fig. 1.

Lenticulina calcar (Linnaeus), Barker, 1960: 146; Hofker, 1969: 52, fig. 124; 1976: 76, fig. 124.

The general features of this species are well-known; though the aperture is sidelong compressed, it is typically radiate allover. The spines form part of the marginal keel. They are hollow as can be seen in the specimens found in fine mud; the infiltrated mud makes the canal in each spine distinguishable. However, this lumen never connects with the lumen of a chamber.

Lenticulina calcar was only found in samples from the slope of the shelf, at depths of $120-400 \mathrm{~m}$.

\section{Lenticulina antillea (Cushman)}

(fig. 2, pl. 8 figs. 6,7) 


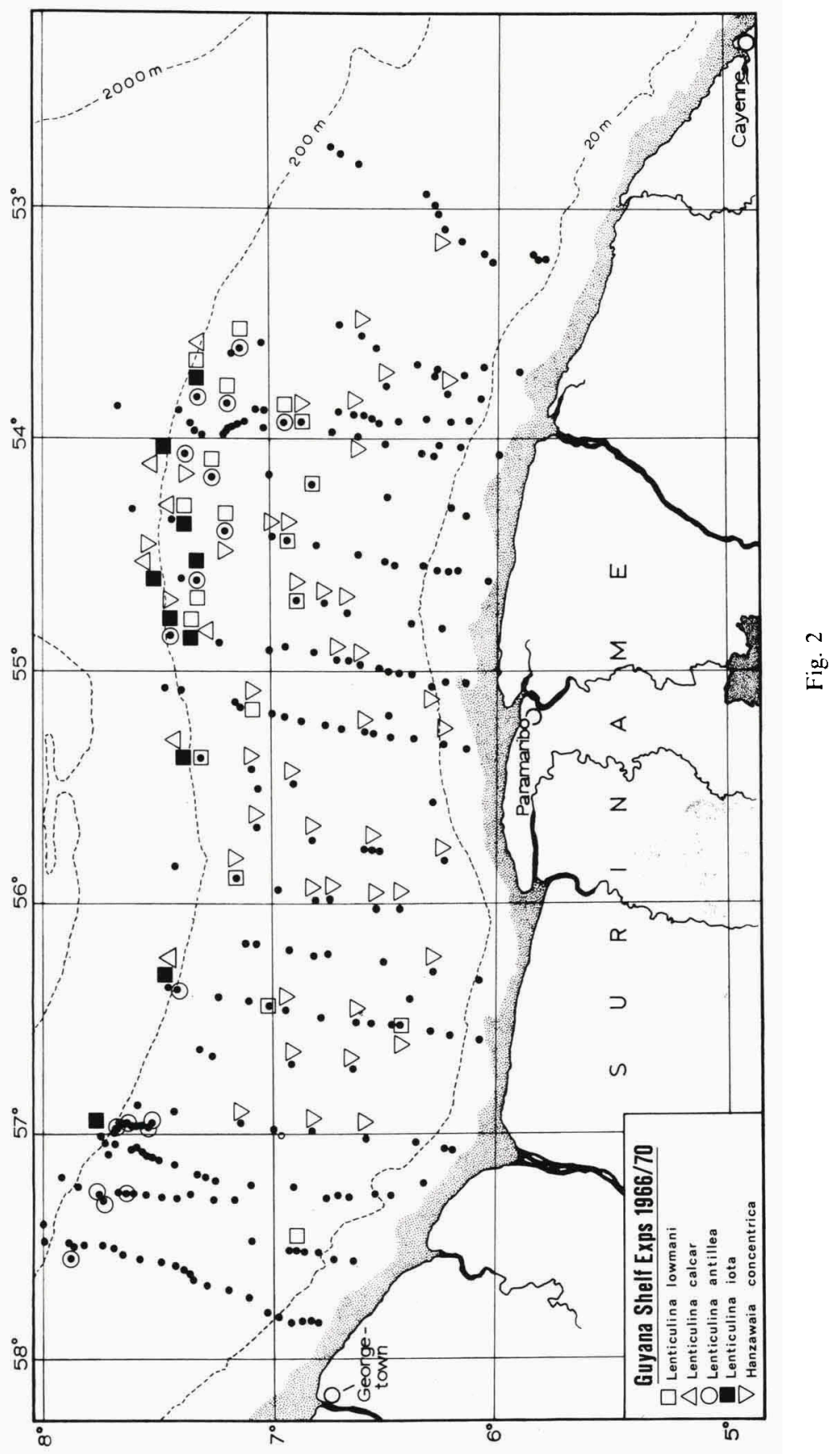




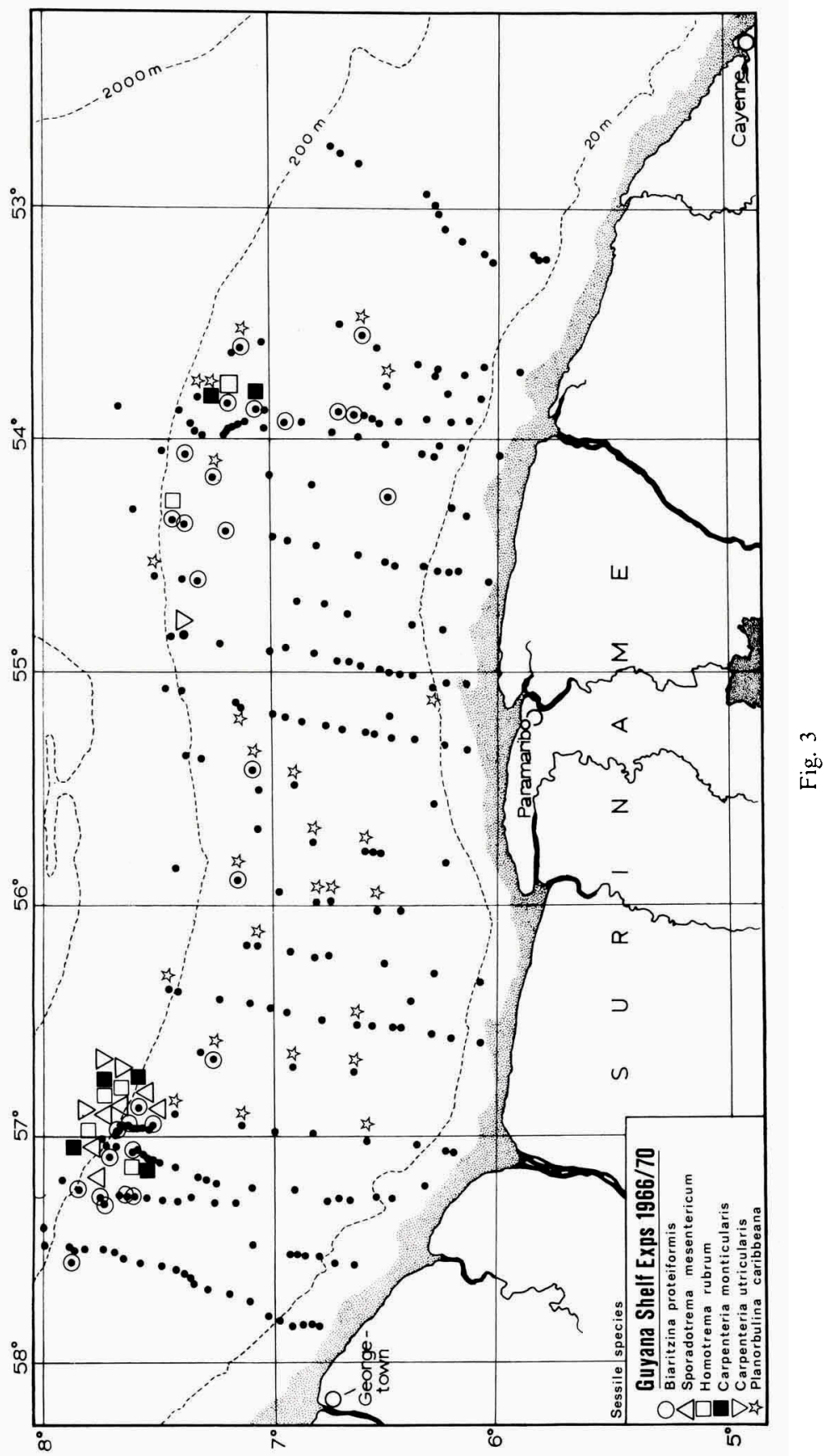




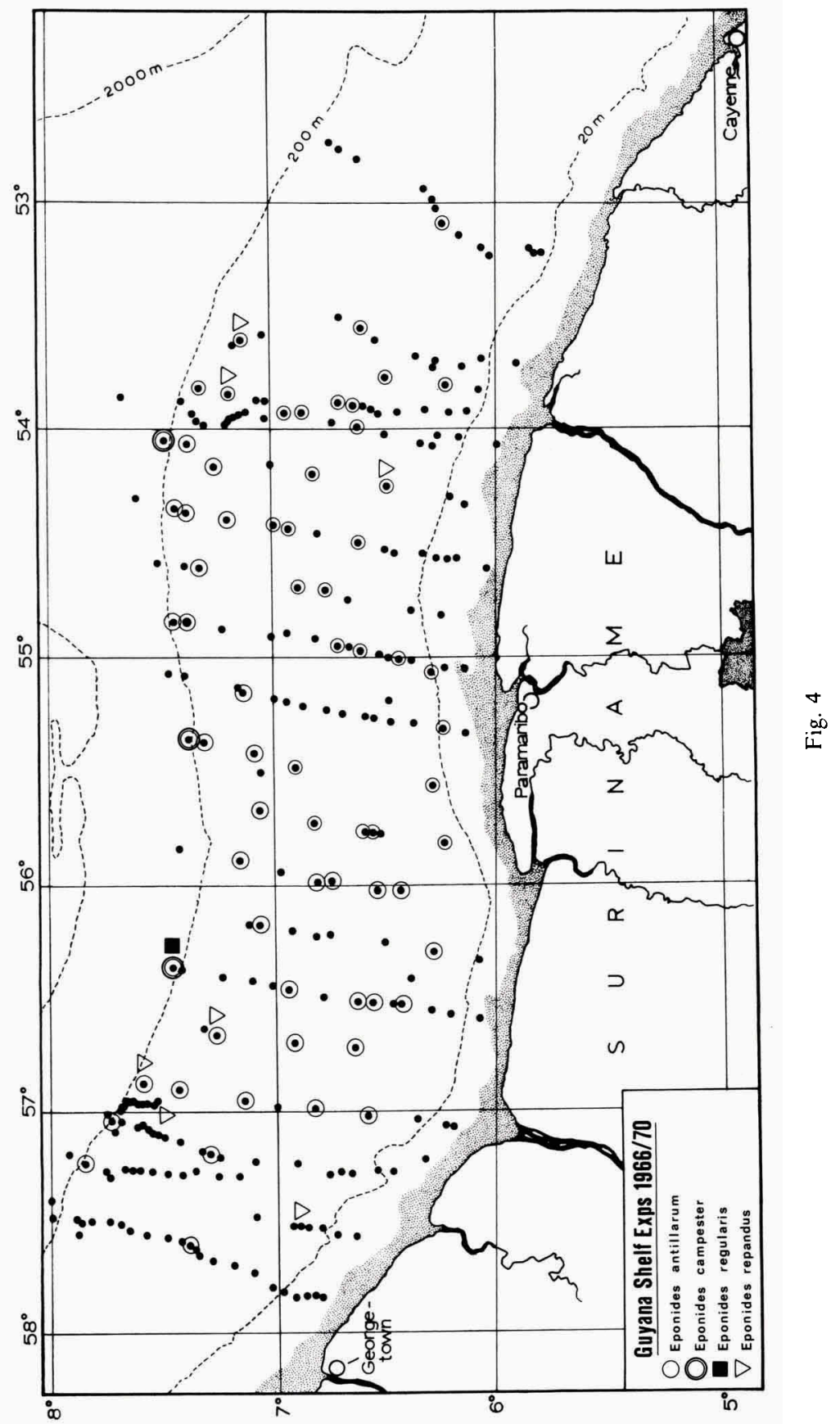




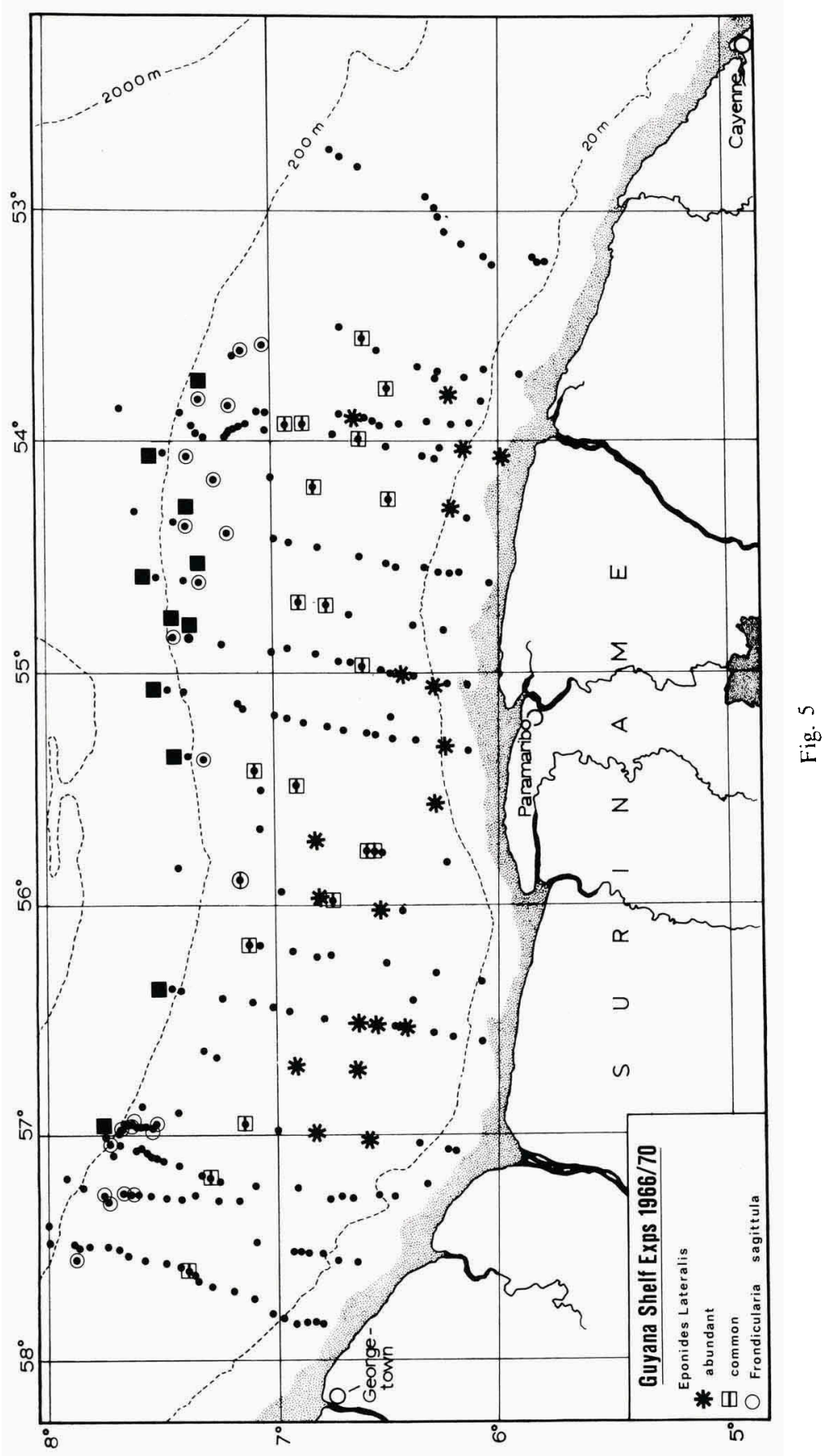




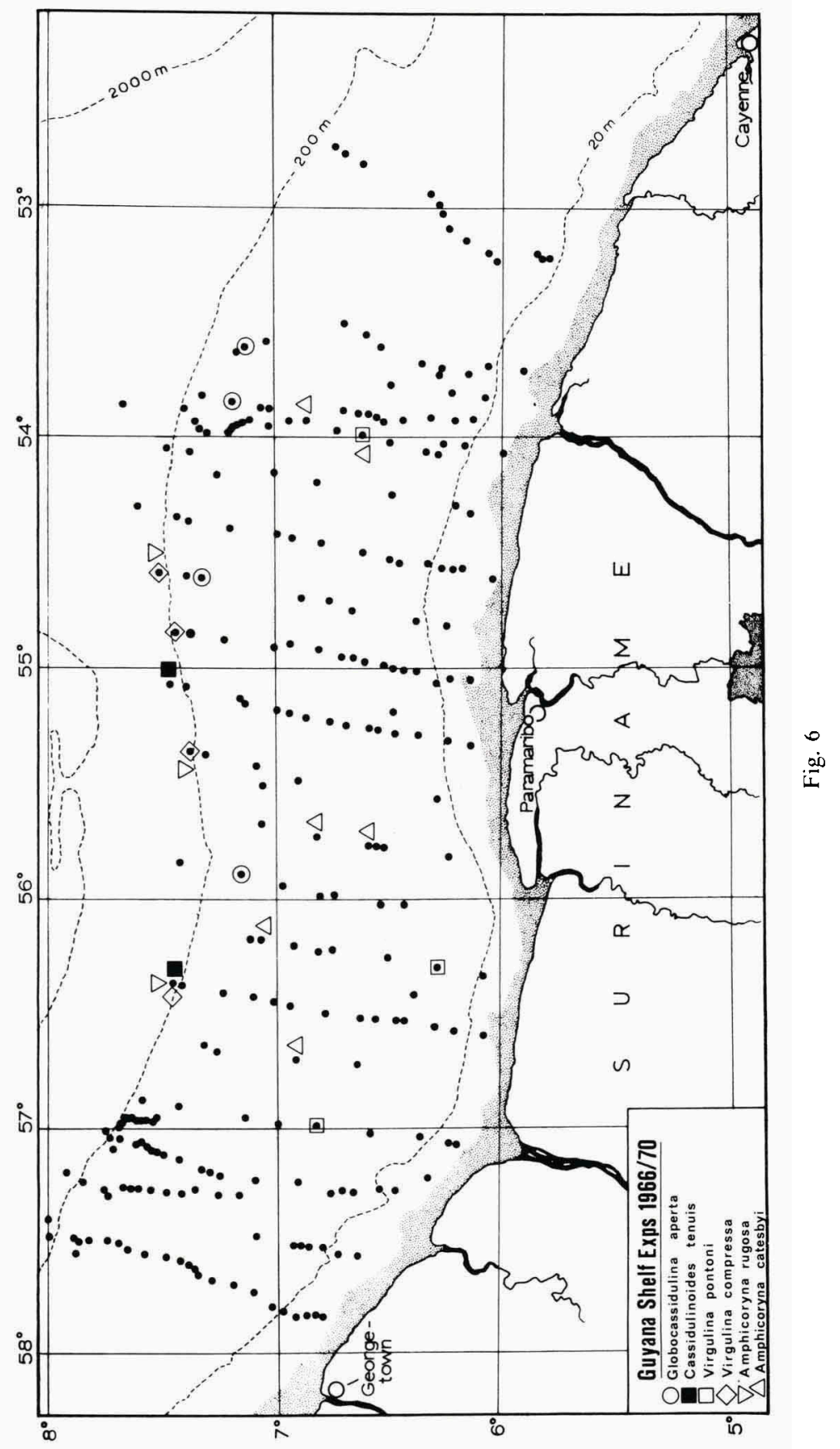




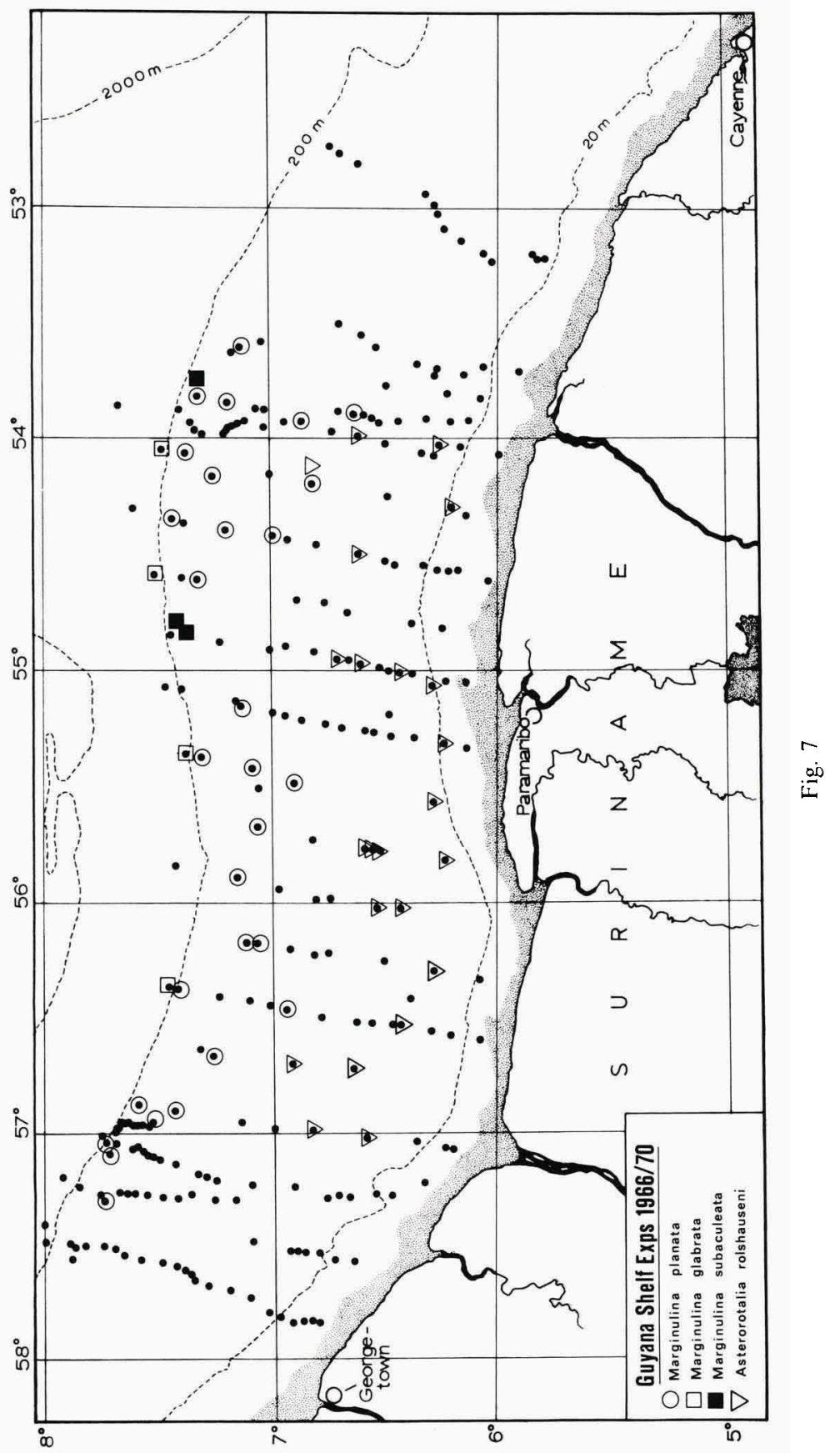




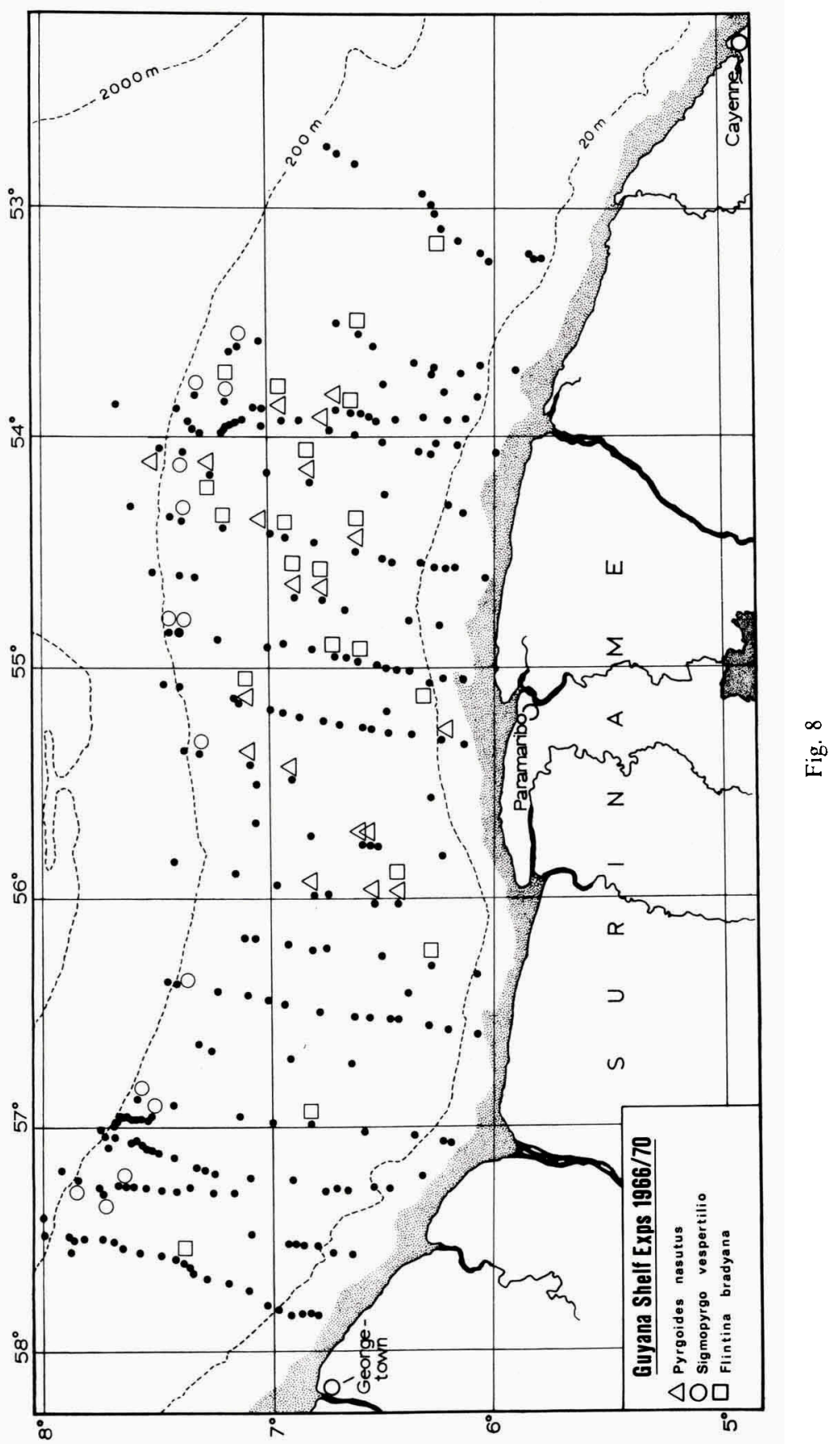


Tests large; larger diameter up to $5.2 \mathrm{~mm}$, much compressed, with irregularly placed acicular spines on the keel. Megalospheric specimens with about 8 chambers visible. Microspheric specimens with up to 15 visible chambers. Sutures distinctly curved backward, slightly impressed, in older chambers with irregularly placed knobs or costae; these knobs are found also near the centre of the test wall. Aperture placed in the middle of the apertural face, an elongate slit wholly surrounded by radiate groves and pustules.

This species is abundant at the border of the shelf, at depths of $86-93 \mathrm{~m}$.

\section{Lenticulina formosa (Cushman)}

Cristellaria formosa Cushman, 1923: 110, pl. 29 fig. I; pl. 30 fig. 6.

Cristellaria calcar Brady (part) (not Linnaeus), 1884: 551, pl. 70 figs. 13, 14; Flint, 1997: 318, pl. 66 fig. 1, only central specimen.

Robulus formosus (Cushman), Bermúdez, 1949: 126, pl. 6 figs. 57, 58; Cushman \& Jarvis, 1930: 358, pl. 32 fig. 10; Renz, 1948: 138, pl. 3 fig. 9.

Lenticulina formosa (Cushman) Palmer, 1940: 128; Barker, 1960: 146.

Test lenticular, about 11 chambers visible with slightly curved and impressed sutures; in the centre of each side the umbilical hollow is filled up by a hyaline knob. Keel with rowel-shaped dents, directed backward, mostly one spine per chamber; keel thin. No other ornamentation, surface smooth and shining. Aperture in the middle of the apertural face, slightly protruding. Diameter of test bout $1.3 \mathrm{~mm}$.

One specimen was found at St. 36 , depth $400 \mathrm{~m}$.

Lenticulina iota (Cushman)

(fig. 2, pl. 9 figs. 2-6)

Cristellaria iota Cushman, 1925: 111, pl. 29 fig. 2; pl. 30 fig. 1.

Cristellaria cultrata (not Montfort), Brady, 1884; 550, pl. 70 figs. 4-6.

Lenticulina iota (Cushman), Barker, 1960: 146; Hofker, 1976: 79, fig. 60.

Lenticulina novangliae (not Cushman), Hofker, 1976: 75, fig. 59.

Robulus iotus (Cushman), Bermúdez, 1949: 127, pl. 6 figs. 67, 68; Andersen, 1961: 51, pl. 13 fig. 4.

Test medium-sized to large, up to $5.5 \mathrm{~mm}$ in diameter, slightly compressed, lenticular, in the megalospheric generation with 8-12 visible chambers, with slightly curved sutures which are flush with the surface, and in the centre of both sides an hyaline umbilical knob which is slightly protruding. At the margin a distinct carina. In the microspheric tests there are about 18 visible chambers, close-coiled. In this generation the keel is very broad. This keel overlaps with its base on both sides the older chambers, and it is not thin, as described by Cushman but thick at its base, though sharp at the periphery. This keel is 
formed by the successive chambers and grows backward over several of the older keels; the pores at the margin pierce the keel also. As the keel remains in the older, not visible chambers, it protrudes in the lumina of the later chambers, which is observed in transverse sections.

Specimens with 8 visible chambers have large proloculi, measuring from 120 to $500 \mu \mathrm{m}$ in diameter; specimens with 12 visible chambers have proloculi of $90-150 \mu \mathrm{m}$ in diameter; the very large specimens with $16-18$ visible chambers have much smaller proloculi, measuring 37-62 $\mu \mathrm{m}$ in diameter. The latter group may belong to the microspheric generation.

The species was found at depths of $88.5-940 \mathrm{~m}$ in the Guyana region; it was very common W of St. Croix, Virginia Archipelago, at a depth of $800 \mathrm{~m}$.

\section{Genus Bulimina d'Orbigny, 1826}

Tests with triserially arranged chambers, in some species tending to become uniserial in later portion of the test. Wall radial in structure. Aperture sutural extending up in the apertural face, with well-developed toothplates with folding free part. All toothplates of the successive chambers forming together an internal tube in the axis of the test. Walls pierced by fine pores, in many species with spines at sutures of chambers. Type species: Bulimina marginata d'Orbigny.

\section{Bulimina marginata d'Orbigny}

(pl. 9 fig. 7)

Bulimina marginata d'Orbigny, 1826: 269, pl. 12 figs. 10-12; Cushman \& Parker, 1949: 119, pl. 28 figs. 5, 6; Hofker, 1951: 154, figs. 95, 96.

Test with triserially arranged chambers. Initial chambers with few elongate spines; later chambers characterized by overhanging proximal margins provided with small dents. Walls thin, very fine and densely placed pores, smooth. Aperture a large comma-shaped opening with its base on the suture with a former chamber; with prominent toothplate which does not protrude from the aperture.

Length of tests about $0.6 \mathrm{~mm}$, thickness $0.35 \mathrm{~mm}$.

Found at the slope of the Surinam Shelf at depths of 132-400 m. 
Bulimina spicata Phleger \& Parker

(pl. 9 fig. 10)

Bulimina spicata Phleger \& Parker, 1951: 16, pl. 7 figs. 25, 30, 31; Hofker, 1956: 74, pl. 8 figs. 1416.

Bulimina striata d'Orbigny var. mexicana Cushman \& Parker, 1940: 16, pl. 3 fig. 9; Cushman \& Parker, 1947: 119, pl. 28 fig. 4.

The name Bulimina striata d'Orbigny var. mexicana was given by Cushman \& Parker to the large microspheric specimens of this species, whereas the smaller megalospheric forms were distinguished by Phleger \& Parker as Bulimina spicata. In samples in which the species is abundant, both forms are found together, the megalospheric form being the commoner form.

Tests of the microspheric form with length about $0.70-1.00 \mathrm{~mm}$, without apical spine, triangular in shape. Proloculus minute, followed by several sets of three small chambers, then volume of chambers rapidly increasing. Chambers in their proximal part with distinct costae ending into short spines in the overlapping proximal margin, in later chambers distal part of chambers without costae. Aperture with sharp border with slightly protruding lip formed by the toothplate; pores somewhat scattered.

Megalospheric specimens smaller and more slender than the microspheric form, never more than $0.55 \mathrm{~mm}$ long, often smaller. The last formed chambers slightly higher than in the microspheric specimens. First chamber large, folowed by a few sets of triserially arranged chambers. Apical end of test with a well-developed spine, surrounded by smaller spines formed by ends of costae on proximal parts of the chamber walls. Aperture elongate comma-shaped, wide open at its distal end, provided with a slightly crenulate border formed by the toothplate.

The species was found from $240 \mathrm{~m}$ to $940 \mathrm{~m}$ deep.

Bulimina aculeata d'Orbigny

(pl. 9 figs. 11-14)

Bulimina aculeata d'Orbigny, 1826: 269, no. 7; Flint, 1897: 291, pl. 37 fig. 4; Brady, 1884: 406, pl. 51 figs. 7-9; Cushman, 1923: 96, pl. 22 figs. 1, 2; Cushman \& Parker, 1947: 120, pl. 28 figs. 8-11; Hofker, 1951: 151, figs. 92-94.

Test club-like, more so in the microspheric than in the megalospheric form. Initial chambers with more or less developed spines, one or more per chamber. Microspheric tests larger (about $0.5-0.6 \mathrm{~mm}$ ) than the megalospheric tests $(0.3-0.4 \mathrm{~mm})$, without the spines. In the microspheric tests the proloculus is found in the base of a large central spine and followed by several trise- 
rial sets of chambers (proloculus-diameter about $10 \mu \mathrm{m}$ ); in the megalospheric test the proloculus shows more than one spines and has a diameter of about $35 \mu \mathrm{m}$. Later formed chambers without spines, inflated, with distinct, impressed sutures. Aperture an elongate slit on the suture with two preceeding chambers, with toothplate with crenulate border. Walls smooth, very finely porous.

This species occurred abundantly at 400 and $940 \mathrm{~m}$.

\section{Bulimina alazanensis Cushman (pl. 9 figs. 8, 9, pl. 10 fig. 1 )}

Bulimina alazanensis Cushman, 1927: 161, pl. 25 fig, 4; Phleger \& Parker, 1951: 16, pl. 7 figs. 2429: Hofker, 1956: 74 pl. 8 figs. $21-25$.

Tests very small, no more than $0.3 \mathrm{~mm}$ in average, characterized by about 5 longitudinal costae visible at each side. The sutures between the chambers are nearly invisible in dry state. Megalospheric specimens small (length about $0.25 \mathrm{~mm}$ ) with a blunt apical end without distinct spine; proloculus with inner diameter of about $30 \mu \mathrm{m}$. Microspheric specimens slightly larger (length up to $0.35 \mathrm{~mm}$ ) with a distinct spine and a proloculus with a diameter of about 10 $\mu \mathrm{m}$.

In 1956 I described the difference between this species and Bulimina rostrata Brady from the Pacific.

Found in samples at depths of $400-940 \mathrm{~m}$.

Genus Protoglobobulimina Hofker, 1951

A genus belonging to the Globobulimina-group, with elongate pores and fine round pores in between. Toothplate without flaring part protruding from the apertural opening.

\section{Protoglobobulimina turgida (Bailey)}

(pl. 10 figs. 2-5)

Bulimina turgida Bailey, 1951: 12, fig. 28-31.

Bulimina (Desinobulimina) turgida (Bailey), Cushman \& Parker, 1940: 20, pl. 3 figs. 22-24.

Globobulimina turgida (Bailey), Höglund, 1947: 248, pl. 20 fig. 5; pl. 21 figs. 4, 8; pl. 22 fig. 5; textfigs. 247-257, 271.

Protoglobobulimina turgida (Bailey), Hofker, 1951: 254, fig. 169.

This species was exhaustively described by Höglund. On the basis of the primitive toothplate, not protruding from the aperture with a flaring wing and 
of the fine pores the species is to be placed in the genus Protoglobobulimina. The abundance of this species in some of the samples enabled me to study the generations; the microspheric generation is very rare and is slightly larger than the megalospheric one; moreover, in the megalospheric generation the last formed chambers often do not reach the initial end of the test (Desinobulimina). The tests are triserial and at the initial end two or three fine spines are formed on each of the chambers. So far, Protoglobobulimina turgida is the only globobulimidid species which is known to form these tiny spines.

The species was found abundantly at depths of $254-940 \mathrm{~m}$.

Genus Reussella Galloway, 1933

Test triserial and triangular. Walls calcareous, with distinct pores, lateral margin carinate and slightly spinose by protruding edges of the chambers, geologically earlier species with simple aperture and simple toothplate, in later, recent species aperture more open whereas the toothplate becomes complicated, showing many small holes below the aperture (see Hofker, 1968, pl. 16, 17). Loeblich \& Tappen (1962: 109) placed these forms in a new genus, Fijiella, which action is not followed here. The type-species of Reussella is Verneuilina spinulosa Reuss.

Reussella atlantica Cushman

(pl. 10 figs. 6,7 )

Not Reussella miocenica Cushman, 1945: 38, pl. 6 figs. 19, 20; Andersen, 1961: 88, pl. 19 figs. 17 , 18.

Reussella spinulosa, var. atlantica Cushman, 1947: 91, pl. 20 figs. 6, 7.

Reussella atlantica Cushman, Phleger \& Parker, 1951: 18, pl. 18 figs. 8, 9; Hofker, 1968: 53, pl. 17.

Tests, if fully grown, elongate, relatively slender, at the margin with many sharp retrograde dents. Chamber walls with distinct pores in the whole chamber wall; the pores are not so fine as in Reussella miocenica Cushman which has two kinds of pores, one kind very fine, the other more distinct and placed more along the peripheries of the chambers.

In Reussella miocenica Cushman the spines are not so distinct as in Reussella spinosissima (Reuss), whereas the toothplates in Reussella miocenica are of a more simple kind; those of Reussella atlantica are very complicated with many openings in the flaring parts of the free wing of the toothplate (Fijiella).

This species occurred in many samples at depths of 36-95 m. 


\section{Reussella mortenseni Hofker}

(pl. 10 figs. 8, 9)

Reussella mortenseni Hofker, 1956: 51, pl. 5 figs. 1,4-7.

Test stout, triangular, with few rounded dents at the margins of the chambers, pores distinct, several rows along the periphery of each chamber. Aperture small, with many pustules at its border; toothplate with serrate border of the free wing, as in Reussella weberi Hofker (1951: 170, fig. 109).

This species was only found in deep water; it occurred in rare specimens on the slope of the Surinam Shelf, at depths of $120-138 \mathrm{~m}$.

\section{Genus Virgulina d'Orbigny, 1826}

Tests elongate, initial part often twisted, suggesting a triserial arrangement of the chambers, later becoming distinctly biserial. Apertures narrow, commashaped, axially placed in some cases becoming areal, but then a closed slit leads to the basal suture. Toothplates invariably slender, with a smooth rim of the free folded part and beginning at the upper part of the toothplate of the former chamber. Walls very thin, may be simple, granular in finer structure. The pores in the walls are very fine and densely placed. The type-species is Virgulina squammosa d'Orbigny.

Virgulina pontoni Cushman (pl. 10 fig. 10)

Virgulina pontoni Cushman, 1932: 17, pl. 5 fig. 7; Phleger \& Parker, 1951: 19, pl. 9 figs. 9, 10; Andersen, 1961: 92, pl. 20 fig. 5.

Test small, compressed, with narrow initial end in specimens with small proloculus and more rounded ends in specimens with somewhat larger proloculus. Chambers elongate, slightly inflated, with slightly inpressed and oblique sutures when seen from the broad side of the test. Walls smooth, fine and densely porous, thin. Aperture a sutural slit at the median side ot the chamber. Toothplate with sigmoid back-side and a smooth rim of the free folded part. Length up to $0.40 \mathrm{~mm}$, breadth up to $0.1 \mathrm{~mm}$, thickness $0.075 \mathrm{~mm}$.

The species was found only on the shelf, $35 \mathrm{~m}$ to $42 \mathrm{~m}$ deep; this is in agreement with the depths reported by Phleger \& Parker (1951: 53). 
Virgulina compressa (Bailey)

(fig. 6, pl. 10 fig. 12)

Bulimina compressa Bailey, 1851: 12, pl. 12 figs. 35-37.

Virgulina compressa (Bailey), Hofker, 1956: 86, pl. 10 figs. 4-11; Phleger \& Parker, 1951: 19, pl. 9 fig. 4.

Test large for the genus, elongate and distinctly compressed, greater width near the end-chambers, sutures at the broad side slightly impressed, curved. Later chambers elongate, more initial chambers twisted and more or less triserial. Wall thin, finely and densely porous, thin. Aperture elongate commashaped and becoming somewhat closed at the base, ending at the apex of the last formed chamber, with slightly thickened border. Toothplate simple, with sigmoid backside of the folded part. Length of tests about $0.85 \mathrm{~mm}$, breadth up to $0.25 \mathrm{~mm}$, thickness $0.15 \mathrm{~mm}$.

The species occurs at depths of $132-400 \mathrm{~m}$, commonly.

Virgulina mexicana Cushman

(pl. 10 fig. 11)

Virgulina mexicana Cushman, 1922: 120, pl. 23 fig. 8; Phleger \& Parker, 1951: 19, pl. 9 figs. 6-8; Andersen, 1961: 91, pl. 20 fig. 4.

Tests stout, of medium size, almost fusiform. Chambers twisted in the initial end, younger chambers biserially arranged. Chambers with strongly oblique sutures, which are moderately impressed. Walls smooth, fine and densely porous. Aperture only open at the top of the chamber, closed towards the basal suture, but comma-shaped. Toothplate with nearly straight backside. Length about $0.65 \mathrm{~mm}$, thickness $0.2 \mathrm{~mm}$.

The species was common at St. 13, depth $940 \mathrm{~m}$.

Remark. The distribution of the species of Virgulina found on the Surinam coast seems to indicate that they are sensitive to different temperatures: $V$. pontoni is found at a minimum of $22^{\circ} \mathrm{C}, V$. compressa at a minimum of $15-$ $8^{\circ} \mathrm{C}$, and $V$. mexicana at a minimum of $5^{\circ} \mathrm{C}$.

\section{Genus Virgulinopsis Hofker, 1956}

Tests triserially arranged in the initial part, but in the end becoming biserial. Fine pores in the walls, but poreless in the apertural face. Walls costae and pores slightly more distinct than in Virgulina. Aperture nearly terminal with flaring toothplate with fimbriate margin. The type-species is Bolivina cubana Bermúdez. 


\title{
Virgulinopsis cubana (Bermúdez)
}

\author{
(pl. 10 fig. 15)
}

Bolivina cubana Bermúdez, 1935: 196, fig. 2; Cushman, 1937: 152, pl. 18 figs. 4, 5. Virgulinopsis cubana (Bermúdez) Hofker, 1956: 47, pl. 4 figs. 8-15.

Test small, consisting of 2 triserial sets of chambers followed by several sets of biserially arranged chambers. Unlike in Virgulina, the wall is highly ornamented by longitudinal, strongly serrate costae; between these costae rows of distinct pores are present. Sutures distinctly impressed, curved to sigmoid. Aperture an elongate slit with its base on the apertural suture. Toothplate with crenulate border. Length of figured test $0.43 \mathrm{~mm}$, thickness $0.18 \mathrm{~mm}$.

The species was found commonly at St. 86, depth $42 \mathrm{~m}$.

\section{Genus Stainforthia Hofker, 1956}

When describing the type-species of Stainforthia, S. concava (Höglund), I (1956: 46) gave the following characteristics: test-wall hyaline (we may now define it having a radial structure), aperture a slit within a hollow opening of which the distal wall is formed by the toothplate (in Virgulina which has a granular wall-structure, the comma-shaped slit of the aperture is found at the outside of the wall and not in a hollow structure); the toothplate is characterized by a distinct, irregularly serrate border of the free folded part of it. The initial part of the test is triserial, but in the end of the development of the test some chambers may become biserially arranged (in Virgulina the initial part is more twisted than triserial). At the initial end a distinct spine of hyaline calcareous matter is formed.

Stainforthia exilis (Brady) (pl. 10 fig. 13)

Bulimina elegans d'Orbigny var. exilis Brady, 1884: 399, pl. 50 figs. 5, 6; Cushman, 1922: 106, pl. 19 figs. $2,3$.

Virgulina skagerakensis Höglund, 1947: 255, fig. 272, pl. 23 fig. 1; pl. 32 figs. 1-3.

Test elongate, slender. Initial part with a short spine, followed by $5-6$ series of chambers arranged triserially, often ending with some biserial chambers. Initial part gradually increasing in diameter, later part cylindrical. First chambers slightly longer than broad, later chambers more elongate. Sutures distinct, slightly impressed, chamber walls slightly inflated. Surface of walls very smooth and shining, hyaline, with radial structure, pores all over the walls, densely placed, very fine. The aperture is found as an elongate slit within the open hollow of which the distal inner wall is poreless and is formed by the 
toothplate; the free folded part of the toothplate has an irregularly serrate rim and can be seen in the apertural hollow. The hollow and the apertural slit have their bases in the sutures of the last formed chamber with the foregoing one. Length: $0.72 \mathrm{~mm}$, larger breadth: $0.12 \mathrm{~mm}$.

The species was found commonly at St. 13, depth $940 \mathrm{~m}$. Cushman found the species at depths of $720-2200 \mathrm{~m}$ in the North Atlantic. In the cold Skagerak Höglund observed it at depths of $200-400 \mathrm{~m}$. This species forms a typical instance of a cold-water form, since at St. 13 the bottom temperature probably did not exceed $5^{\circ} \mathrm{C}$.

Genus Bolivina d'Orbigny, 1839

The genus Bolivina includes species characterized by chambers arranged in a spiral with a speed of $1 / 2\left(=180^{\circ}\right)$; this can be proved by the position of the toothplates. The walls are calcareous and all species possess apertures with folded toothplates which together form a gully which leads the enzymatic protoplasm towards the last formed aprerture. The walls are porous, with or without ornamentation. These walls consist in the Jurassic of aragonite, in the Cretaceous of granular calcite and in the Tertiary to the Recent of radiate calcite, thus proving the change during time of calcareous walls in general. As the wall-structure is not of generic value, there is no reason to choose a new genus for the Tertiary-Recent radiate species of Bolivina, the genus Brizalina Costa, 1856, as Loeblich \& Tappan did. Moreover, the genus Bolivinita Cushman, 1937 has all the characteristics of Bolivina, and even Bolivinoides Cushman, 1927, belonging to the group of Bolivina with retral processes over the sutures, and possibly even Afrobolivina Reyment, 1959, with its more complicated toothplates, must be incorporated into the genus Bolivina d'Orbigny, 1839. (See for the change in finer calcareous structure of foraminiferal walls Hofker, 1967.)

Bolivina mexicana Cushman

$$
\text { (pl. } 11 \text { figs. 1-3) }
$$

Bolivina subaenerensis Cushman var. mexicana Cushman, 1922: 47, pl. 8 fig. 1 .

Test slender, elongate, in both generations 3 times as long as broad, with apical spine which in the microspheric generation is better developed than in the megalospheric one. Sutures strongly oblique, especially in the B-form, with in the axis a distinct bend towards the axis. Ornamentation consists of 4-5 straight, longitudinal winged costae over nearly all the chambers. Aperture small, slit- to comma-shaped with its base on the suture, toothplate simple 
with sigmoid dorsal back-side. Pores rather fine, densely placed over the whole chamber wall. Proloculus B-form about $15 \mu \mathrm{m}$, in the A-form about $45 \mu \mathrm{m}$. Length of tests in the A-form $0.75 \mathrm{~mm}$, breadth $0.25 \mathrm{~mm}$, thickness $0.10 \mathrm{~mm}$, in the B-form resp. $0.90 \mathrm{~mm}, 0.30 \mathrm{~mm}$ and $0.10 \mathrm{~mm}$.

On the slope of the shelf, at depths of $120-940 \mathrm{~m}$.

Bolivina goesii Cushman

(pl. 11 figs. 4-6)

Bolivina punctata d'Orbigny, var., Goës, 1882: 70, pl. 4 figs. 124-126.

Bolivina goesii Cushman, 1922: 34, pl. 6 fig. 5; Phleger \& Parker, 1951: 13, pl. 6 fig. 17.

Bolivinita? goesi (Cushman), Hofker, 1956: 40, pl. 3 figs. 32-34.

Bolivina pseudogoesi Hofker, 1956: 40, pl. 7 figs. 35-42.

Test compressed, with sharp marginal keel. Test strongly tapering towards the apertural end, sutures distinct, often slightly protruding, limbate, especially in the axis of the test, oblique and slightly curved. Walls distinctly porous, pores often somewhat scattered over the chamber walls. Aperture small, in the axis of the test, with small, often reduced, toothplate. Length of tests up to $0.36 \mathrm{~mm}$, breadth up to $0.19 \mathrm{~mm}$, thickness $0.06 \mathrm{~mm}$.

As I could find microspheric and megalospheric specimens together, I figure them here. Found on the slope, at depths of 120-138 m.

Remark. In some samples specimens are found without any trace of the toothplate; I described them as Bolivinita ? goesi (Cushman) in 1956, but I now believe that toothplates are easily dissolved in this species; so I cancel here the names proposed in 1956 and return to the name, given by Cushman in 1922.

\section{Genus Rectobolivina Cushman, 1927}

Tests beginning as Bolivina, ending in a straight series of chambers in uniserial arrangement. The toothplates in the biserial part show a spiral of speed $1 / 2$, and this speed is continued in the uniserial part, as the apertures continue the speed $1 / 2$; we must conclude that in the uniserial part the chambers continue the mode of growth found in the biserial part. Type-species is Sagrina bifrons Brady.

\section{Rectobolivina advena (Cushman)}

(pl. 11 figs. 13, 14)

Siphogenerina advena Cushman, 1922: 35, pl. 5 fig. 2; Bermúdez, 1935: 199. Bifarina decorata Phleger \& Parker, 1951: 12, pl. 6 figs. 9, 10. 
Bifarina advena (Cushman), Drooger \& Kaasschieter, 1958: 26, pl. I fig. 1. Bifarina (Rectobolivina) advena (Cushman), Hofker, 1956: 72, pl. 8 figs. 5-13. Rectobolivina advena (Cushman), Andersen, 1961: 95, pl. 19 fig. 6.

This species was fully described by me in 1956. In the abundant material now at hand two generations were found, the microspheric generation with a proloculus of about $27 \mu \mathrm{m}$, number of biserial chambers 7 , uniserial chambers 7 , and the megalospheric generation with proloculus of about $40 \mu \mathrm{m}$ diameter, 4 biserial chambers and 5 uniserial chambers. Especially in the generation with a small proloculus the initial part of the tests is ornamentated by many longitudinally elongate pustules. Fig. 8 of pl. 8 in the publication of 1956 shows such an ornamentated specimen.

The species was observed at depths of $36-120 \mathrm{~m}$.

\section{Genus Globocassidulina Voloshinova, 1960}

Tests subglobular; chambers biserially arranged and enrolled. Wall finely porous and granular in structure. Aperture a narrow slit, often with protruding rim, but the toothplate wholly reduced; in some species the aperture tends to become areal. Type-species: Cassidulina globosa Hantken.

Globocassidulina aperta nov. spec.

(fig. 6, pl. 11 figs. 7-9)

Cassidulinoides porrecta Osterman \& Kellog (not Parr), 1979: 264, pl. 2 figs. 8, 9.

Test large for the genus, consisting of few bulbous chambers which are biserially arranged but do not cover the large proloculus which is visible in all specimens observed. The aperture is a partly open slit with at one side a serrate protruding rim which is probably a rest of the reduced toothplate. The aperture has no contact with the suture and thus is wholly areal. The sutures are curved and slightly impressed. The pores in the walls are extremely fine and very densely placed. Length of tests $1.10 \mathrm{~mm}$ or slightly less, breadth about $0.80 \mathrm{~mm}$, thickness $0.50 \mathrm{~mm}$. The small number of the chambers and the bulbous form of them makes it difficult to unravel the biseriallity of the chambers. The proloculus-diameter was in all specimens observed about 200 $\mu \mathrm{m}$.

Whether Cassidulinoides porrecta Osterman \& Kellog is identical with our species, is uncertain, since their figures are so bad; it is certainly not the species which was described by Parr (1950: 344, pl. 12 fig. 26); nor is it the species described as such by Heron-Allen \& Earland (1932: 358, pl. 9 figs. 34-37); in 
both descriptions and figures the specimens have apertures which are distinctly sutural and not areal; moreover, the specimens described are much smaller and have more chambers.

Genus Cancris Montfort, 1808

Tests more or less elongate, compressed with sharp margin, trochospiral, last formed chamber closing the ventral umbilical area by a poreless plate which is the tenon of the chamber wall. Chambers rapidly enlarging. Test consisting of one convolution of chambers. Walls finely porous. Aperture on the umbilical side, a narrow slit at the suture of the last formed chamber. The type-species is Cancris auriculus (Fichtel \& Moll).

\section{Cancris sagrai d'Orbigny}

(pl. 11 fig. 10)

Rotalina sagra d'Orbigny, 1839: 77, pl. 5 figs. 13-15.

Cancris sagra (d'Orbigny), Cushman, 1931: 74, pl. 15 fig. 2; Hofker, 1956: 202, pl. 31 figs. 1-9.

Tests broad-oval, much compressed, periphery sharp, slightly keeled. Test at the dorsal side nearly flat, at the ventral side convex. Chambers forming one to two convolutions, sutures simple, curved slightly. Chambers rapidly increasing in size, last formed chamber forming half of the whole test; walls very finely and densely porous, but for the part of the last formed chamber which covers the ventral umbilical cavity, which part is poreless.

Length of figured specimen $0.40 \mathrm{~mm}$; breadth $0.25 \mathrm{~mm}$; thickness $0.08 \mathrm{~mm}$.

Remark. D'Orbigny states that this species is "la Rotalina de Sagra." The paper in which d'Orbigny published in 1839 is "L'Histroire de Cuba par M. Ramon de la Sagra"; the name of the species thus is not Cancris sagra but Cancris sagrai ( = de Sagra).

\section{Genus Hanzawaia Asano, 1944}

The genus Hanzawaia is a Discopuvinulina or a Discorbis with the chambers overlapping former coils and concealing them totally. At the ventral side the chambers show slit-like apertures near the umbilical cavity, whereas a reduced protoforamen is also visible, separated from the deuteroforamen by a more or less distinct tenon. In this way the protoforamina form a circle concentric with the border of the umbilical cavity as well as with the margin of the test. All species are compressed and seem to live attached to a substratum with their ventral sides. 
Hanzawaia concentrica (Cushman)

(fig. 2, pl. 11 figs. 11, 12, pl. 12 fig. 1)

Truncatulina concentrica Cushman, 1919: 64, pl. 21 fig. 3; 1930: 6l, pl. 12 fig. 4.

Cibicides concentrica (Cushman), Cushman, 1931: 120, pl. 21 figs. 4, 5; pl. 22 fig. 2.

Discopulvinulina cushmani Hofker, 1955: 128, textfig. 1.

Cibicides concentricus (Cushman), Phleger \& Parker, 1951: 29, pl. 15 figs. 14, 15.

Hanzawaia concentrica (Cushman), Bermúdez, 1952: 88.

Test oval, much compressed, with sharp periphery; ventral side flattened, dorsally with slightly inflated chambers. Sutures depressed in the megalospheric generation at the dorsal side, in the microspheric generation sutures in the more initial chambers distinctly limbate. At the ventral side in both generations the sutures are flush, curved backward, as they are at the dorsal side. Periphery in the megalospheric generation lobulate, in the microspheric one without lobulation. Aperture marginal, with distinct protruding border, running as a narrow slit at the ventral side towards a broad tenon which for a large part conceals the umbilical cavity, ending in an irregular lip; proximal to this lip the suture opens to form a distinct protoforamen before the suture is running curving backward to the periphery. Since each chamber forms such a tenon and protoforamen, the tena seem to fuse together into a flat band around the umbilical cavity. In the microspheric generation this cavity is wider than in the megalospheric one. In the megalospheric generation the visible chambers wholly overlap the more initial chambers; in the microspheric generation the more initial chambers remain partly visible as the chambers do not reach the centre. The walls at the dorsal side are pierced by fine pores, whereas at the ventral side pores are found only in the peripheral part of the chamber walls.

Length of specimens examined up to $0.80 \mathrm{~mm}$, generally smaller. Most specimens are left-coiling, some are coiling to the right, in both generations.

The species lives attached with its ventral flat side to shells by means of irregular protuberances of fine white calcareous matter. The species was found on the shelf from $18 \mathrm{~m}$ to $254 \mathrm{~m}$, in agreement with the observations by Cushman (1931: 30) and by Phleger \& Parker (1951: 45).

\section{Genus Eponides Montfort, 1808}

Tests trochospiral, bivonvex or only convex at the dorsal side. At the dorsal side all chambers visible, at the ventral side only those of the last formed whorl. Sutures curved backward at the dorsal side, radial at the ventral one. Walls consisting of an inner granular layer and a radial one at the outside; newly built chambers have the granular layer only. Walls finely perforate in 
the type species, but in several other species coarser pores may occur also. Septa not primarily double. Primarily aperture a more or less open slit along the suture, closed at or before the closed umbilicus in young specimens, in adult tests opening into an open umbilical cavity. Sometimes adult specimens show areal round secondary apertures in the ventral walls of the last formed chambers (Poroeponides Cushman, 1944). In microspheric adult specimens the umbilical cavity is closed by a plate formed by the large tenon of the endchamber (Sestronophora Loeblich \& Tappan). It is probable that these openings have a function with the reproduction. The type-species is Nautilus repandus Fichtel \& Moll. Believing that the type was lost, Reiss created the genus Eponidopsis Reiss, 1960; the discovery of the collection of Fichtel and Moll made this genus superfluous and a synonym of Eponides. In the same year Reiss erected the genus Neoeponides for species which show thickened sutures, secondary thickening of the septa forming a ring around the "pseudoumbilicus". The fact that in Eponides antillarum (d'Orbigny) specimens developed in shallow water are typical Eponides, whereas in deeper water they develop in adult specimens the characteristics of Neoeponides makes the latter a synonym of the former. In a study of the genus Eponides (Hofker, 1970: 2227) I made it clear that the microstructure of the walls in this genus is very variable and thus cannot be taken as a characteristic of this genus.

\section{Eponides repandus (Fichtel \& Moll)}

(fig. 4, pl. 12 figs. 2-4)

Nautilus repandus Fichtel \& Moll, 1798: 35, pl. 3 figs. a-d.

Eponides repandus (Fichtel \& Moll), Montfort, 1808: 127, genre 32; Cushman, 1927: pl. 16 fig. 9.

Pulvinulina repanda Carpenter, 1862: 210.

Test trochospiral, periphery angled and carinate, biconvex to planoconvex, spiral side evolute and flattened, umbilical side elevated and involute, later chambers tending to become inflated. Chambers broad, low, arched, increasing more rapidly in breadth than in height. Sutures curved at the dorsal side, more straight at the ventral one. Wall calcareous, finely porous, radial at the outside, with inner granular layer. In some localities the specimens may form blunt pustules at the dorsal side. Aperture a ventral slit without toothplate. Umbilical cavity closed in young specimens, but may become open in the adult. In the end of the development of megalospheric specimens the last formed chamber or chambers may form secondary round and areal openings (Poroeponides) or, in microspheric specimens the large tenon of the last formed chamber may grow over the umbilical cavity, and also show these areal secondary apertures (Sestronophora). Resig (1962: 55-57, pl. 14), Colom 
(1964: 518, pl. 4 figs. 1-10) and Hofker (1970: 22) showed that all these forms belong to one species; in consequence they are synonyms of Eponides.

Eponides lateralis (Terquem)

(fig. 5, pl. 12 figs. 5-12, pl. 13 fig. 1)

Rosalina lateralis Terquem, 1878: 25, pl. 2 figs. $11 \mathrm{a}-\mathrm{c}$.

Pulvinulina lateralis (Terquem) Brady, 1884: 689, pl. 106 figs. 2, 3.

Small specimens are scarcely distinguishable from small specimens of Eponides repandus, but outgrown specimens differ in that they show a larger number of chambers in the last formed whorl, and that these later chambers are higher; the result is that this species becomes strongly oval in shape. Moreover, the later chambers at the ventral side do not reach any more the umbilical centre and thus form a real umbilical cavity. Mostly the tests become flattened with a sharp margin and the last formed chambers form nearly half of the test. At the ventral side the last formed chambers show secondary rounded apertures (Poroeponides-form) and often the whole ventral wall of the last formed chamber shows these secondary openings, whereas the ventral wall may lengthen till over the ventral umbilical cavity, a tenon over this cavity (Sestronophora-form). As these large tena have a thin wall, they are easily broken off. The species seems to be an attached form on shells and weeds (Cushman, 1944: 34).

This species was found, often abundantly, at depths of 8-96 m. Microspheric specimens were found at 85 and $96 \mathrm{~m}$ depth only.

\section{Eponides antillarum (d'Orbigny)}

(fig. 4, fig. 9, pl. 13 figs. 2-7)

Rosalina antillarum (d'Orbigny), 1839: 75, pl. 5 figs. 4-6.

Eponides antillarum (d'Orbigny), Cushman, 1931: 42, pl. 9 fig. 2; Drooger \& Kaasschieter, 1958: 45, map 5.

Rotalia antillarum (d'Orbigny), Hofker, 1956: 166, pl. 25 figs.11-21.

Neoeponides antillarum (d'Orbigny), Reiss, 1960: 17; Andersen, 1961: 102, pl. 23 figs. 4, 5, Hofker, 1969: 143, figs. 462-469.

Test unequally biconvex, dorsal side more convex than the ventral one, margin subacute. Chambers of the last formed whorl (seen from the ventral side) in specimens in shallow water (27 to about $52 \mathrm{~m}$ ) 4-6, at depths of 45$98 \mathrm{~m} 7-9$. The specimens found in shallow water are smaller than those which lived in deeper water. Moreover, only in samples of deeper water (85$98 \mathrm{~m}$ ) microspheric specimens were found. Sutures oblique at the dorsal side, 
indistinct, radiate and slightly impressed at the ventral side. The tests from shallow water are not ornamentated, but those from deeper water have crenulated ventral sutures, and the ventral umbilicus, slightly open (pseudo-umbilicus) is then bordered by a thicker wall, formed by the thick tena of the chamber walls. The aperture is a slit at the ventral suture of the last formed chamber, which wall forms an apertural face developing a hook with the main ventral wall; the border of the aperture shows a thickened lip in many tests. There are no toothplates; there exists a small infundibulum at the marginal end of the aperture. The finer structure of the walls consists of an inner granular layer and an outer more hyaline one; the pores are somewhat coarser than in $E$. repandus and E. lateralis.

The gradual increase in diameters and in number of chambers in the last formed whorl with the depth of the sea-floor is remarkable. Moreover the specimens from deeper localities show more and more the characteristics of what Reiss called the genus Neoeponides; the specimens from shallow water invariably show the characteristics of Eponides; it is obvious that the genus-name Neoeponides is a synonym of Eponides; it is unthinkable that in one species with gradual change of characteristics this change would result in evolving from one genus into another one.

The species is one of the commonest species on the Surinam Shelf.

Eponides campester Palmer \& Bermúdez

(fig. 4, pl. 14 figs. 1-4)

Eponides byramensis (Cushman) var. cubensis Palmer \& Bermúdez, 1936: 302, pl. 20 figs. 4-6.

Eponides byramensis (Cushman) var. campester Palmer \& Bermúdez, Palmer, 1941: 192.

Gyroidinoides byramensis (Cushman) var. campester (Palmer \& Bermúdez), Renz, 1948: 139, pl. 8 fig. 13, pl. 9 fig. 1.

Eponides bermudezi Keyzer, 1945: 55.

Eponides campester Palmer \& Bermúdez, 1949: 245, pl. 16 figs. 40-42.

Eponides petrosa Bermúdez, 1949: 247, pl. 17 figs. 10-12.

This species is known from the Miocene on; in the large (1.1 mm diameter) microspheric generation which was called by Bermúdez Eponides petrosus, the number of chambers in the last formed whorl is about 14; at the dorsal side the sutures are beaded and there is a distinct knob in the centre; the chamber sutures are strongly curved backward. At the ventral side the slightly impressed sutures are radiate and straight, whereas the umbilical region is covered by irregular knobs and bosses, formed by the ends of the former chamber walls. The margin is lobulate in the six last formed chambers.

In the megalospheric generation, which is by far the commonest, the tests are smaller $(0.7-0.9 \mathrm{~mm})$, the dorsal side is nearly flat or slightly inflated, 
whereas the ventral side is strongly inflated. At the dorsal side about $7-8$ chambers are visible in the last formed whorl and the sutures of the chambers are strongly curved backward, distinctly beaded and protruding, with a central knob covering the initial chambers. At the ventral side there is a small open pseudoumbilicus with many knobs around it, from which the straight impressed sutures radiate.

In both generations the aperture is a sutural slit, not reaching the margin and formed in a distinct flat apertural face without pores. In the megalospheric generation the proloculus is large for the genus (diameter $75 \mu \mathrm{m}$ ) and the walls are thick at the dorsal side (see Hofker, 1970c: 173-182). The tena of the chambers are distinctly bossed and without pores. Pores densely placed and extremely fine, as in Eponides repandus, the type-species of the genus. The walls are radially hyaline. In the microspheric form the proloculus is small (diameter $12 \mu \mathrm{m}$ ), the walls are very thick and the umbilicus is filled up by the irregular bosses of the tena of the last whorl of chambers.

The species was found at depths of $95-400 \mathrm{~m}$ on the slope of the shelf. It replaces in this way Eponides antillarum in the column of water, as the latter species is found down to $98 \mathrm{~m}$ (see fig. 9).

Genus Cibicides Montfort, 1808

Tests free or adhered to substratum, trochospiral. At the spiral or dorsal side all chambers visible, at the other side chambers strongly overlapping and reaching the centre of this side, without an umbilicus. So we speak here of spiral side (comparable with the umbilical (or ventral) side of other rotalid genera) and of umbilical side (though there is no real umbilicus and it is comparable with the dorsal side of other rotalid genera). Test wall granular or radial, pores mostly distinct. Aperture a low slit, interior-marginal, often with lip, and closed by a calcareous plate in older chambers.

Loeblich and Tappan would place all species mentioned here in the genus Heterolepa Franzenau; however, as the characteristics of Heterolepa are nearly identical with those of Cibicides Montfort, and most authors name the species mentioned here Cibicides, I have placed all these species in the genus $\mathrm{Ci}$ bicides.

\section{Cibicides robustus Phleger \& Parker}

$$
\text { (pl. } 15 \text { figs. 1-4) }
$$


Tests large for the genus, spiral side nearly flat or slightly convex, umbilical side more convex; margin rounded to slightly subacute. At the spiral side 1012 chambers in the ultimate coil, at the umbilical side chambers reaching the centre with thickened walls filling up the centre with an hyaline knob, flush with the surface and with radial sutures. Periphery at the last formed chambers slightly lobulate. At the spiral side sutures slightly raised, at the centre the last formed chambers with a distinct grove. Central part of this side mostly with irregular bosses of hyaline matter covering the initial chambers completely. Pores at both sides distinct, often coarse. Aperture an open slit extending from the peripheral third part of the suture over the margin and ending at the spiral side. Walls of the more initial chambers thick in transverse section and granular, but in the central part of the umbilical side the knob consists of hyaline material; this knob shows many layers of the secondary thickening. All foramina in the septal walls have a thickened border and are situated at the spiral side only, caused, obviously by partly closing the apertures at the spiral side. The pores are tubular, especially in the umbilical central thickening. The horizontal section shows that all foramina have the thickened border. The septa show an inner preformed granular layer, gradually changing in the outer more hyaline layer of the walls. This is the finer structure of all septa found in the genus Cibicides and this is not a typical bilamellar structure of the septa.

Diameter of the tests about $0.7 \mathrm{~mm}$, thickness $0.3 \mathrm{~mm}$.

Phleger and Parker found it in samples of the Gulf of Mexico at depths of $120-900 \mathrm{~m}$; Flint mentioned it from the Gulf also and from the Brazilian coast in depths varying from 210 to 1019 fathoms; in samples from the Guyana Shelf I found it from $132 \mathrm{~m}$ to $400 \mathrm{~m}$, often commonly.

\section{Cibicides antilleanus Drooger}

$$
\text { (pl. } 14 \text { figs. 5, 6) }
$$

Cibicides pseudoungerianus (Cushman) var. antilleanum Drooger, 1953: 146, pl. 23 figs. 1, 2; Drooger \& Kaasschieter, 1958: 40, pl. 2 fig. 2.

Cibicides antilleanum Drooger, Hofker, 1969: 61, figs. 165-169.

This species was fully analyzed by the present author in 1969 ; most characteristic are the thick walls around the initial part, the much thinner walls of the chambers of the ultimate whorl, at the outside the umbilical ventral hyaline knob formed by the thick walls of the earlier chambers and, in the larger microspheric specimens, the irregular growth of the later chambers, also mentioned by Drooger. Diameter of test about $0.6 \mathrm{~mm}$, thickness about $0.2 \mathrm{~mm}$.

This species was found in the samples of the Guyana Shelf at depths va- 
rying from 95 to $400 \mathrm{~m}$, often commonly to abundantly. Rarely found on the slope of the Saba Bank (Hofker, 1980), it was common at a depth of $200 \mathrm{~m} \mathrm{~W}$ of Barbados (Hofker, 1969), by Parker in the Gulf of Mexico at depths of 46$1829 \mathrm{~m}$, but most commonly at about $200 \mathrm{~m}$. It lives with its flat side attached to shells.

\section{Cibicides pseudoungerianus (Cushman)}

$$
\text { (pl. } 15 \text { figs. } 5,6 \text { ) }
$$

Truncatulina ungeriana Brady, 1884 (not d'Orbigny): 664, pl. 94 fig. 9.

Truncatulina pseudoungeriana Cushman, 1922: 97, pl. 20 fig. 9.

Cibicides pseudoungeriana (Cushman), Cushman, 1931: 122, pl. 23 figs. 3-5.

This species is biconvex, the umbilical side generally more so than the spiral side. The acuteness of the margin is caused mainly by an inward nick of the chamber walls parallel to the periphery at the umbilical (involute) side. This characteristic is well figured by Brady and by Cushman, however, it is not seen in the figure of Cibicides pseudoungeriana by Drooger \& Kaasschieter (1958: 39, pl. 2 fig. 2); so this may be another species, or the figure is incorrect. Diameter about $0.6 \mathrm{~mm}$, thickness about $0.25 \mathrm{~mm}$. C. pseudoungerianus was collected on the slope of the Surinam Shelf at depths varying from $120 \mathrm{~m}$ to $940 \mathrm{~m}$.

Remark: the megalospheric proloculi are very large: diameters up to 150 $\mu \mathrm{m}$.

\section{Cibicides mollis Phleger \& Parker}

$$
\text { (pl. } 16 \text { figs. 1,2.) }
$$

Cibicides mollis Phleger \& Parker, 1951: 30, pl. 16 figs. 7-9.

Tests small, biconvex, mostly on the spiral side less convex than on the involute or umbilical side. Number of chambers in the last formed whorl 7-8; periphery slightly lobulate, margin subacute, at the spiral side initial coils invisible by thickening of the wall, sutures directed backward; at the umbilical or involute side sutures slightly impressed and sigmoidal to curved. Pores at both sides distinct. Walls in last formed chambers thin, in former coils much thicker, especially at the centre of the spiral as well as at the umbilical sides. Aperture a short crescent with somewhat thickened border just over the margin. Proloculus in megalospheric specimens rather large. Diameter of tests about $0.5 \mathrm{~mm}$, thickness $0.25 \mathrm{~mm}$.

The species is common in samples from depths of $95-254 \mathrm{~m}$. This is in agreement with the data given by Phleger \& Parker for the Gulf of Mexico. 
Tests discoidal, trochospiral in the initial part, attached by the spiral side, tests in both generations of similar size. Early portion spirally coiled, each chamber with one foramen (aperture), later two apertures on each chamber, each giving rise to a new biapertural chamber, thus making a clock-anticlockwise growth. Type-species: Planorbulina mediterranensis d'Orbigny. (See Loeblich \& Tappan, 1964: 693.)

\section{Planorbulina caribbeana Hofker}

$$
\text { (pl. } 16 \text { figs. 3, 4) }
$$

Planorbulina caribbeana Hofker, 1976: 140, fig. 133.

Planorbulina mediterranensis (not d'Orbigny), Cushman, 1922: 45, pl. 6 figs. 1, 2; 1931: 129, pl. 24 figs. 5-8; Hofker, 1969: 135, fig. 429.

“Planorbulina mediterranensis"Schnitker, 1969: pl. 15 figs. 4, 5.

Spiral side of test flattened or concave. Umbilical side with inflated chamberwalls. At the spiral side all chambers visible, at the umbilical one initial spiral invisible by overlapping of later chambers, leaving a small umbilical cavity open. Spiral of about 10 initial chambers, beginning with a small proloculus, diameter of proloculus $25-35 \mu \mathrm{m}$ (see Le Calvez, 1938, many figures in text); these first chambers have a single aperture, but later chambers have two small apertures at both ends of their margins, a proximal and a distal one, whereas the arrangement of the chambers becomes more irregular. Chambers near the margin much broader than high, so that in the end only few (4 to 8) chambers form the periphery. Periphery lobulate, margin rounded. Pores distinct at the spiral side, smaller in diameter than at the umbilical side, which is the visible side when the specimen is attached. Especially the initial chambers are brownish coloured by the inner pseudochitinous membrane.

Diameter of tests up to $1 \mathrm{~mm}$, thickness $0.1 \mathrm{~mm}$.

Found commonly in samples from depths of 20-130 m, but elsewhere (not on the Surinam shelf) also in much deeper water.

\section{Genus Biarritzina Loeblich \& Tappan, 1964}

Tests attached to substratum, often molluscs, with a basal spiral of chambers, later growing upright in a loose spiral, tending to become uniserial. Wall thick in the upright part, pierced by pores, in the inner layer of the wall densely placed, which pores in the outer layer often fuse into larger holes. In this way at the outside there seem to exist two kinds of pores, smaller ones (not 
having been fused) and larger ones, developed by fusing. Aperture at the end of the test with bordering lip on a neck of imperforate calcite (see Loeblich \& Tappan, 1964: 628).

Biarritzina proteiformis (Goës)

(fig. 3, pl. 16 figs. 5, 6)

Carpenteria balaniformis var. proteiformis Goës, 1882: 94, pl. 6 figs. $208-214$, pl. 7 fig. 215.

Carpenteria proteiformis (Goës), Brady, 1884: 679, pl. 97 figs. 8-14; Cushman, 1931: 140, pl. 26 fig. 1; Hofker, 1930: 130, pl. 46 figs. 1, 4, 5, 7; pl. 52 figs. 6, 8; 1970a: 87, 88, pl. 52 figs. $4-7$. Biarritzina proteiformis (Goës), Hofker, 1969: 148, figs. 474-484.

Tests consisting of an horizontal spiral of chambers, followed by a straight or branched stem formed by larger, semiglobular chambers spirally or irregularly arranged around the axis of the stem. Walls calcareous, thick, consisting of two layers, the inner one with many coarse pores which fuse at the boundary with the outer layer into much fewer large openings. Initial chambers with simple walls, consisting of the inner layer with the densely placed pores. Though the species is very close to Sporadotrema, which always is richly coloured, the colour of $B$. proteiformis is white or slightly yellowish; walls at the surface nearly smooth. Apertures formed by peculiar smoothly finished necks without pores ending open forming the aperture. Occasionally two apertures are formed in an end-chamber which may give rise to branching. Later chambers overlapping the apertures of former chambers.

The species is attached to shells, calcareous algae, large Foraminifera, corals. On the Surinam and Guyana shelf it is found at depths of $44-254 \mathrm{~mm}$. In the shallower depths down to $88 \mathrm{~m}$ the specimens remain small with few chambers; at depths of $88-120 \mathrm{~m}$ the specimens are well-developed with many large chambers; at depths down to $254 \mathrm{~m}$ they once again become small. So the species finds its optimum temperature at $18^{\circ}$ to $14^{\circ} \mathrm{C}$ according to Eisma \& Van Bennekom (1971). W of Barbados the species was common to abundant at depths of $100 \mathrm{~m}$ and $200 \mathrm{~m}$ (Hofker, 1969).

\section{Genus Sporadotrema Hickson, 1911}

Tests large, often tree-like or spread over the substratum in irregular mossy complexes. Irregularly growing parts in holes of the substratum ending in stems or branched trees, consisting of a spiral of large vesicular chambers with tube-like apertures fusing together in the centre of the stem and thus forming the apertures at the ends of the stems and branches. These apertures are mostly filled with sponge-spicules protruding from the apertures. The specimens 
are yellowish or orange in colour in $S$. cylindricum Carter, deep-red in $S$. mesentericum Carter and rosa in $S$. rubrum (d'Orbigny). Walls consisting of two layers, the inner one with densely placed coarse pores, which fuse to form distinct hollows in the outer layer of the wall.

\section{Sporadotrema mesentericum (Carter)}

(fig. 3, pl. 17 figs. 1, 2)

Polytrema mesentericum Carter, 1880: 437.

Sporadotrema mesentericum (Carter), Hickson, 1911: 452, pl. 30 fig. 5; pl. 31 figs. 11, 12; Hofker, 1927: 24 , pl. 8 figs. $1,2,4,7$; pl. 10 figs. 11-13.

Sporadotrema cylindricum (not Carter), Hofker, 1969: 145, figs. 470-473; 1970a: 87, pl. 51 figs. 10,14 ; pl. 52 figs. I-3; pl. 54 figs. 3,5 .

Tests often large, a single stem, or a stem with branches. Chambers irregularly spirally arranged and several shorter or longer branches often in one plane, sometimes in several directions. Sporadotrema cylindricum and $S$. mesentericum are mainly differing in the colour of the tests, those of $S$. cylindricum being yellow to orange, those of $S$. mesentericum deep red. In the Indonesian waters $S$. mesentericum mostly forms irregular mossy tests, but in the Caribbean Sea and on the Surinam Shelf they have the form of trees, very much resembling the tree-like tests of S. cylindricum. In 1969 and 1970 I believed the tests found in the Caribbean to belong to $S$. cylindricum. As I pointed out in 1927 , both species have quite similar structures in their tests and it is probable that we have here only one species, varying in colour in different environments.

Stems in the material of the Guyana Shelf measure up to $8 \mathrm{~mm}$ long.

Found on the Guyana Shelf at depths of 70-98 m. The species was not found by Phleger \& Parker in the Mexican Gulf, nor by Drooger \& Kaasschieter (1958) in the nearby Orinoco-Trinidad-Paria Shelf.

\section{Genus Homotrema Hickson, 1911}

Tests attached, early stage trochospiral or of the raspberry type, later growth irregular, extending upward from the substratum, sometimes becoming branched. Apertures large, formed by the ends of the central tube which is formed by the successive apertural necks of the chambers. Pores in groups piercing thin plates closing the tubes. Colour always deep-red. 


\section{Homotrema rubrum (Lamarck)}

(fig. 3, pl. 17 figs. 3, 4)

Millepora rubra Lamarck, 1816: 202.

Polytrema rubra (Lamarck), Dujardin, 1841: 259; Carpenter, Parker \& Jones, 1862: 235, pl. 13 figs. $18-20$.

Homotrema rubrum Hickson, 1911: 445, 454, pl. 30 fig. 2, pl. 31 fig. 9, pl. 32 figs. 19, 22, 28; Cushman, 1931: 143; Hofker, 1927: 31, pl. 13 figs. 8, 9, pl. 14 figs. 12-30, pl. 13; 1970: 82, pl. 51 figs. 1-5, pl. 54 figs. 1, 2.

This encrusting species was fully analysed by Hofker (1927, 1970); it is generally found in warm water, growing on shells and corals. In the samples from the slope of the Guyana Shelf it was found in deeper and cooler water, depths $70 \mathrm{~m}$ to $132 \mathrm{~m}$; whereas in tropical shallow water the species mostly forms irregular crusts as a moss, in the deeper water of the Shelf it forms a stem with irregular branches; this may be the deep-water form of Homotrema, but, as all finer structures are those of the warm water form, I believe that it is the same species but in another environment.

Genus Asterorotalia Hofker, 1950

A genus very close to Ammonia; the main difference is found in the intercalating of secondary chamberlets covering the ventral sutures, each chamberlet forming an extra foramen near to the margin of the test at the ventral side. These extra chamberlets seem to have been formed by the toothplates which show the structure of the toothplates as found in Ammonia. Yet these intercalated structures are real chamberlets, since their ventral walls show pores.

\section{Asterorotalia rolshauseni (Cushman \& Bermúdez)}

(fig. 7 , pl. 17 figs. $5-11$ )

Rotalia rolshauseni Cushman \& Bermủdez, 1946: 119, pl. 19 figs. 11-13; Phleger \& Parker, 1951 : 23, pl. 12 fig. 10.

Rolshausenia rolshauseni (Cushman \& Bermúdez), Bermúdez, 1952: 63 pl. 9 fig. 8.

Asterorotalia rolshauseni (Cushman \& Bermúdez), Hofker, 1971: 29, pl. 72 figs. 5-13.

The intercalated porous plates covering the ventral sutures and, via the protoforamina, connected with the toothplates, together with the poreless margin are the typical characteristics of Asterorotalia; they are well-developed in $A$. rolshauseni also. There was no reason to create the genus Rolshausenia and the latter thus becomes a synonym of Asterorotalia. A. rolshauseni was fully described by Hofker (1971). It occurred in samples from depths of $18-45 \mathrm{~m}$.

Remark. There seem to be three generations, the B-generation with very 
small proloculus (diameter 5-10 $\mu \mathrm{m}$ ), the $\mathrm{A}_{1}$-generation with larger proloculus (diameter about $35 \mu \mathrm{m}$ ) and the $A_{2}$-generation, proloculus diameter 60 $\mu \mathrm{m}$. The B-generation is rare; most B-specimens are dextrally coiling, a single specimen appeared to be sinistral; all $A_{1}$-specimens, forming the bulk of the specimens, are sinistrally coiling; the $A_{2}$-specimens are never common and generally sinistral. The only sinistral B-specimen begun its spiral in the right direction, and then suddenly started to form its chambers in a left coil (see fig. 8); so we may conclude that the normal direction of coiling in the microspheric generation is dextral, whereas in the megalospheric generations the direction is sinistral.

The microspheric generation has all coils with 6 chambers, whereas the megalospheric generations have coils with 5 chambers.

In fig. 7 the distribution of Asterorotalia rolshauseni in the samples from the Surinam Shelf is clearly indicated: in a band parallel to the coast it was found in may samples at depths of $18-45 \mathrm{~m}$. It is a typical shallow-water species. 


\section{REFERENCES}

ANDERSEN, H.V., 1951. Foraminifera of the mudlumps ... In: Genesis and paleontology of the Mississippi River Mudlumps, 2. - Publ. Louisiana Dept. Conserv. Geol. Bull., 35: 1-208.

AsANo, K. 1951. Illustrated catalogue of Japanese Tertiary Foraminifera. - Tokyo, pt. Rotaliidae, 14.

BAGG, R.M., 1912. Pliocene and Pleistocene Foraminifera from southern California - U.S. Geol. Survey, Bull., 513: 5-92.

BAILEY, J.W., 1851. Microscopical examination of soundings made by the U.S. Coast Survey off the Atlantic coast of the U.S. - Smithsonian Contr. Knowl., 2 (3): 1-15.

BARKER, R.W., 1060. Taxonomic notes on the species figured by H.B. Brady in his report on the Foraminifera dredged by HMS Challenger. — Soc. Econ. Pal. and Min., Spec. Publ., 9: 1238.

Bermúdez, P.J., 1935. Foraminiferos de la costa norte de Cuba. -- Soc. Cubana Nat. Hist., Mem., 8: 129-224.

- 1949. Tertiary smaller Foraminifera of the Dominican Republic. - Cushman Lab. For. Res., Spec. Publ., 25: 1-322.

- 1952. Estudio systematico de los Foraminiferos rotalifornes. — Bol. Geol. Venezol., 2 (4): $1-230$.

BLOw, W.H., 1969. Late middle Eocene to Recent planktonic foraminiferal Biostratigraphy. In: P. Brönniman \& H.H. Renz (eds.), Proceedings first international conference on planktonic microfossils, Geneva 1967, 1: 199-421, pls. 1-54.

BoltovskoY, E., 1956. Diccionario foraminiferologio plurilingue: 1-196.

- 1957. Los Foraminiferos del estuario del Rio de la Plata y su zone de influencia. - Rev. Inst. Nac. Invest. Cienc. Nat., Geol., 6 (1): 1-77.

_- 1959. Foraminiferos recientes del Sur de Brasil y sus relaciones con los de Argentina e India del Oeste: 1-124, Buenes Aires.

Bornemann, J.G., 1855. Die mikroskopische Fauna des Septarien Thones von Hermsdorf bei Berlin. - Ztschr. deutsch. geol. Ges., 7: 307-371.

BraDY, H.B., 1881. Notes on some of the Reticularians-Rhizopoda of the Challenger-Expedition, III, Classification, further notes on new species and note on Biloculina-mud. - Quart, Journ. Microsc. Sci., 19: 31-71.

- 1884. Report on the Foraminifera dredged by HMS Challenger during the years $1873-$ 1876. - Zool. 9: 1-814.

BroeCK, E. vaN DEN, 1876. Etude sur les Foraminifères de la Barbade (Antilles) receuillis par C. Agassiz, précédé de quelques considérations sur la classification et la nomenclature des Foraminifères. -.Ann. Soc. Belge microsc., 2 (1): 55-152.

CAdÉE, G.C., 1975. Primary production off the Guyana Coast. - Neth. Journ. Sea Res., 9: 128143.

- 1975. Lunulitiform Bryozoa from the Guyana Shelf. — Neth. Journ. Sea Res., 9: 320-343.

CAlvez, J. LE, 1938. Recherches sur les Foraminifès. - Arch. zool. expérim. et générale, 80: $163-333$.

Calvez, LE, 1974. Foraminifères des lles Canaries. - Cahiers Micropaléont., 2: 1- 108.

-.. 1977a. Révision des Foraminifères de la collection d'Orbigny, II. Foraminifères de l'Ile de Cuba, I. _ Cahiers Micropléont., 1977 (1): 1-127.

- - 1977b. Foraminifères de l'lle de Cuba, II. - Cahiers Micropaléont., 1977 (2): 1-129.

CARpenter, W.B., W.K. Parker \& T.R. Jones, 1862. Introduction to the study of the Foraminifera: 1-319. Ray Soc., London.

CARTER, H.J., 1880. Report on specimens dredged from the Gulf of Manaar, and presented to the Liverpool Free Museum by Capt. W.H. Caurie Warren. - Ann. Mag. Nat. Hist., (5) 5: 437 457.

Christiansen, B.O., 1965. A bottom form of the planktonic foraminifer Globigerinoides rubra (d'Orbigny). - Pubbl. Staz. zool. Napoli, 34: 197-202. 
CICAR II Symposium, 1976. Distribution of physical and chemical oceanographic data in the CICAR region. Pt. 2, computer plot displays. - Data Center, Washington.

Colom, D.G., 1964. Estudios sobre la sedimentacion costera Balear (Mallorca, y Menorca). Mem. Real Acad. Ci. Art. Barcelona, 34 (15): 495-550.

Cushman, J.A., 1910. A monograph of the Foraminifera of the North Pacific Ocean, pt. 1, Astrorhizidae and Lituolidae. - U.S. Nat. Mus., Bull. 71, I: VIII--XIV, 1-134.

_-., 1919. Some Pliocene and Miocene Foraminifera of the coastal Plain of the United States. Bull. 676, U.S. Nat. Survey, 1918 (Jan. 1919);: 45-87.

- 1920. The Foraminifera of the Atlantic Ocean, pt. 2, Lituolidae. - U.S. Nat. Mus., Bull., $102(2): 1-111$.

- 1921. Foraminifera of the Phillippines and adjacent seas. _ U.S. Nat. Mus., Bull., 100 (4): $1-608$.

-.... 1922. The Foraminifera of the Atlantic Ocean, pt. 3, Textulariidae. - U.S. Nat. Mus. Bull., 104: 1-149.

- 1923. The Foraminifera of the Atlantic Ocean, pt. 4, Lagenidae. - U.S. Nat. Mus., Bull., 104 (4): $1-178$.

-1927. Recent Foraminifere from the west coast of America. - Bull. Scripps Instit. Oceanogr., Rechn. Ser., I: 119-188.

-1929. The Foraminifera of the Atlantic Ocean, pt. 6, Miliolidae, Ophthalminidae and Fischerinidae. - U.S. Nat. Mus., Bull., 104 (6): 1-101.

- 1930. The Foraminifera of the Choctawhatchee Formation of Florida. - Florida State Geol. Survey, Bull., 4: 25-38.

-1932. Foraminifera of the tropical collections of the "Albatros", 1895-1900. - Bull. U.S. Nat. Mus., 161: 1-88.

, 1935. Fourteen new species of Foraminifera. _ Smiths. Misc. Coll., 91: 1-9.

-1937. A monograph of the foraminiferal family Valvulinidae. - Cushman Lab. For. Res., Spec. Publ., 8: 1-210.

1937. A monograph of the subfamily Virgulinidae of the foraminiferal family Buliminidae. - Cushman Lab. For. Res., Spec. Publ., 9: 1-228.

- 1943. The megalospheric and microspheric forms of Frondicularia sagittula Van Den Broeck and their bearing on specific descriptions. - Contr. Cushman Lab. For. Res., 19: 25-26.

- 1945. The species of the subfamily Reussellinae of the foraminiferal family Buliminidae. Contr. Cushman Lab. For. Res., 21: 23-54.

- -1947 . New species and varieties of Foraminifera from off the southeastern coast of the United States. - Contr. Cushman Lab. For. Res., 23: 86-92.

Cushman, J.A. \& P.J. Bermúdez, 1946. A new genus, Cribropyrgo, and a new species of Rotalia. - Contr. Cushman Lab. For. Res., 22: 119-120.

Cushman, J.A. \& H.B. Grey, 1946. A foraminiferal fauna from the Pliocene of Timms Point, California. -Cushman Lab. For. Res., Spec. Publ., 19: 1-46.

Cushman, J.A. \& P.W. Jarvis, 1930. Miocene Foraminifera from Buff Bay, Jamaica. - Journ. Paleont., 4: 353-368.

Cushman, J.A. \& F.L. Parker, 1931. Recent Foraminifera from the Atlantic coast of South America. - Proc. U.S. Nat. Mus., 80 (3): 1-24.

- 1940: The species of the genus Bulimina having Recent type. - Contr. Cushman Lab. For. Res., 16: 24-26.

-...., 1947. Bulimina and related foraminiferal genera. - U.S. Geol. Survey Prof. Paper 210-D: $55-176$

Cushman, J.A. \& R. Todd, 1945. Miocene Foraminifera from Buff Bay, Jamaica. - Cushman Lab. For. Res., Spec. Publ., 15: 1-73.

- 1947. Foraminifera from the coast of Washington. - Cushman Lab. For. Res., Spec. Publ., 21: $1-23$.

Drooger, C.W., 1953. Miocene and Pleistocene Foraminifera from Oranjestad, Aruba (Netherlands Antilles). - Contr. Cushman Found, For. Res., 4: 86-92. 
Drooger, C.W. \& J.P.H. KaAsschieter, 1958. Foraminifera of the Orinoco-Trinidad-Paria Shelf. - Verhand. Kon. Nederl. Akad. Wetensch., ser. 1, 22:1-108.

Dujardin, M.F., 1841. Histoire naturelle des Zoophytes; Infusoires: 1-684. Paris.

EISMA, D., 1967. Oceanographic observations on the Surinam Shelf. - Hydrogr. Newsl., Spec. Publ., 5: 21-55.

EISMA, D. \& A.J. VAN BENNEKOM, 1971. Oceanographic observations on the eastern Surinam Shelf. - Hydrogr. Newsl., Spec. Publ., 6: 25-55.

Fichtel, L. v. \& J.R.C. V. Moll, 1978. Testacea microscopica aliaque minuta ex generibus; Argonauta et Nautilus: I-VIII, I-123. Vienna.

FLINT, J.M., 1897. Recent Foraminifera. A descriptive catalogus of specimens dredged by U.S. Fish Commision steamer Albatros. - Rep. Nat. Mus., 1897: 251-349.

Franzenau, A., 1884. Heterolepa, egy uj genus a Foraminiferak rendjeben. - Termeszetrajzi Füzetek, 8: 214-217.

GoËs, A., 1882. On the reticularian Rhizopoda of the Caribbean Sea. - Handl. K. Svenska Vet. Akad., 19 (4): 1-151.

-..- 1894. A synopsis of the arctic and Scandinavian Recent marine Foraminifera hitherto discovered. - K. Svenka Vet. Akad., Handl., 25: 1-127.

Hickson, S.J., 1911. On Polytrema and some allied genera. A study of some sedentary Foraminifera based mainly on a collection made by Prof. Stanley Gardiner in the Indian Ocean. Trans. Linn. Soc. London (Zool. Ser. 2), 14: 443-462.

Hofker, J., 1930. The Foraminifera of the Siboga Expedition, pt. 2. - Siboga Repts, IVa, 2: 79170.

1950. Wonderfull animals of the sea, Foraminifera. - Amsterdam Naturalist, 1: $60-79$.

- 1951. The Foraminifera of the Siboga Expedition, Ordo Dentata. - Siboga Exped. Repts, IVa, 3: 1-513.

- 1955. Discopulvinulina cushmani Hofker, a new name for Hanzawaia concentrica (Cushman). - Contr. Cushman Found. For. Res., 6: 128-130.

- - 1956. Foraminifera dentata, Foraminifera of Santa Cruz and Thatch Island, Virg. Archip., West-Indies. - Spolia Zool. Mus. Haun., 15: 1-237.

- 1960 . Foraminiferen aus dem Golfe von Neapel. - Paläont. Zeitschr., 34: 233-262.

- 1967 . Hat die feinere Wandstruktur der Foraminiferen supra-genetische Bedeutung? Paläont. Zeitschrift, 41: 194-198.

—, 1968. Studies of Foraminifera. — Publ. Natuurhist. Gen. Limburg, pt. 1, 18: 1-135.

- 1969. Recent Foraminifera from Barbados. — Studies on the Fauna of Curaçao and other Caribbean Islands, 31: 1-158.

_-., 1970a. Studies of Foraminifera, pt. 2, Systematic problems. - Publ. Natuurhist. Genootsch. Limburg, 20: 1-98.

1970b. The increase of proloculus-diameter in Bolivinoides. - Micropal., 2: 173-182.

- 1971. Studies of Foraminifera, pt. 3, systematic problems. — Publ. Natuurhist. Genootsch. Limburg, 21: 1-202.

1972. Primitive agglutinated Foraminifera: 1-95. Brill, Leiden.

- 1976. Further studies on Caribbean Foraminifera. - Studies of the Fauna of Curaçao and other Caribbean Islands, 49: $1-256$.

_.... 1978. Biological results of the Snellius Expedition XXX, The Indonesian Archipelago. Zool. Verhandl. Leiden, 161: 1-69.

— 1980. Foraminifera of the Saba Bank Exped., 1972. - Zool. Verhandl. Leiden, 177: 1-73.

Höglund, H., 1947. Foraminifera in the Gullmar Fjord and the Skagerak. - Zool. Bidrag. Uppsala, 26: $1-328$.

KEIJZER, F.G., 1945. Outline of the geology of the eastern part of the province of Oriente, Cuba, with notes on the geology of other parts of the island: 1-239. Diss. Utrecht Univ.

LAMARCK, J.B.P.A. DE, 1816. Histoire naturelle des animaux sans vertèbres, 2: 1-568.

LiNNAEUS, C., 1767. Systema naturae (Gmelin ed.), 6: 1-824.

LOEBLICH, A.R. \& A. TAPPAN, 1957. Eleven new genera of Foraminifera. - U.S. Nat. Mus. Bull., 215: 173-198. 
Loeblich, A.R. \& H. TAPPAN, 1961. Suprageneric classification of the Rhizopoda. - Journ. Paleont., 35: 173-198.

- 1962. Six new names in the Mycetozoida and Foraminifera, and a redescription of Loxostomum. - Biol. Soc. Washington Proc., 75: 107- 113.

- 1964. Sarcodina, chiefly Thecamoebians and Foraminiferida. In: R.C. Moore (ed.). Treatise on invertebrate paleontology, C., Protista, $2(1-2): 1-900$.

MCLean, J.D.. 1956. The Foraminifera of the Yorkstown Formation in the York-James Peninsula of Virginia, with notes on the associated mollusks. - Bull. Amer. Paleont., 36 (160): 261394.

MikHalewich, B.N., 1976. New species of Foraminifera on the shelf in the northeastern part of South America. - Zool. Jurnal. 55: 445-449.

- 1977. New species of Foraminifera of the northwestern coast of Africa. - Zool. Instit. Acad. Sci. U.S.S.R.; Explor. fauna of the seas, 21: 5-9.

MontFort. Denis DE, P., 1808. Conchyliologie systématique et classification méthodique des coquilles, 1: 1-409. Paris.

Orbigny. A. D', 1826. Tableau méthodique de la classe des Céphalopodes. - Ann. Sci. nat., Paris, (1) 7: 245-314.

_- 1839. Foraminifères. In: De la SAGRA, Hist. phys., pol. et nat. de l'Ile de Cuba, 2: 1-224.

-.., 1946. Foraminifères fossiles du Bassin Tertiaire de Vienne: I-XXXVII, 1 -312. Paris.

Osterman, L.E. \& T.B. KelloG, 1979. Recent benthic foraminiferal distributions from the Ross Sea. Antarctic: relation to ecologic and oceanographic conditions. - Journ. Foram. Res., 9: 250-269.

PALMER, D.K., 1941. Foraminifera of the Upper Oligocene Cojimar formation of Cuba, pt. 4. Mem. Soc. cubana Hist. Nat., 15: 181-200.

Palmer, D.K \& P.J. Bermúdez, 1936. Late Tertiary Foraminifera from the Matanzas Bay region, Cuba. - Soc. cubana Hist. Nat., Mem., 9: 237-257.

Phleger, F.B. \& F.L. Parker, 1951. Ecology of Foraminifera, Northwest Gulf of Mexico; pt. I, Foraminifera distribution; pt. II, Foraminifera species. - Geol. Soc. of America, Mem., 46: I-88; $1-64$.

Pozaryska. K., 1957. Lagenidae du Crétacé supérieur de Pologne. - Paleontologia Polonica, 8: $1-190$.

REISS, Z., 1960. Structure of so-called Eponides and some other rotaliform Foraminifera. — Israel Geol. Survey, Bull., 291: 1-28.

RENZ, H.H., 1948. Stratigraphy and fauna of the Aqua Salada group, State of Falcon, Venezuela. - Geol. Soc. America, Mem., 32: 1-219.

RASHEED, D.A., 1971. Some foraminifera belonging to Miliolidae and Ophthalmidiidae from Coral Sea, south of Papua (New Guinea). Pt. II. - Madras Univ. Journ., 1971, Sect. B, 37-38 (1967-1968): 42.

Resig, J.M., 1962. The morphological development of Eponides repandus (Fichtel \& Moll), 1798. - Contr. Cushman Found. For. Res., 8: 55-57.

Schlumberger, C., 1891. Révision des Biloculines des grands fonds. - Mém. Soc. Zool. France, 4: 42-179.

SCHNItKer, D., 1969. Cibicides, Caribbeanella and the polyphyletic origin of Planorbulina. Contr. Cushman Found. For. Res., 20: 67-69.

Sidebotrom. H., 1909. Report on the recent Foraminifera from the coast of the Island of Delos (Grecian Archipelago). - Mem. Proc. Manchester Lit. Phil. Soc., 53: 1-30.

Terquem, O., 1878. Les Foraminifères et les Entomostracés-Ostracoda du Pliocèce de l'Ile de Rhodes. - Soc. géol. France, Mém., Sér. 3, 1: 1-135.

Thalman, H.E., 1937. Mitteilungen über Foraminiferen. pt. 3. - Ecog. geol. Helv., 30: 337-356.

TodD, R., 1963. Nomenclature of Foraminifera. — Contr. Cushman Found. For. Res., 14: 109111.

TodD, R. \& P. BrónNimanN, 1957. Recent Foraminifera and Thecamoeba from the eastern Gulf of Paria. - Cushman Found, For. Res., Spec. Publ., 3: 1-43. 
VERvoORT, W., 1967. Zoological exploration of the continental shelf of Surinam. - Hydrogr., Newsl., Spec. Publ., 5: 61-81.

- 1971. Scientific investigations on the shelf of Surinam with H.Nl. M.S. Luymes, 1969. Hydrogr. Newsletter, Spec. Publ., 6: 37-50. 


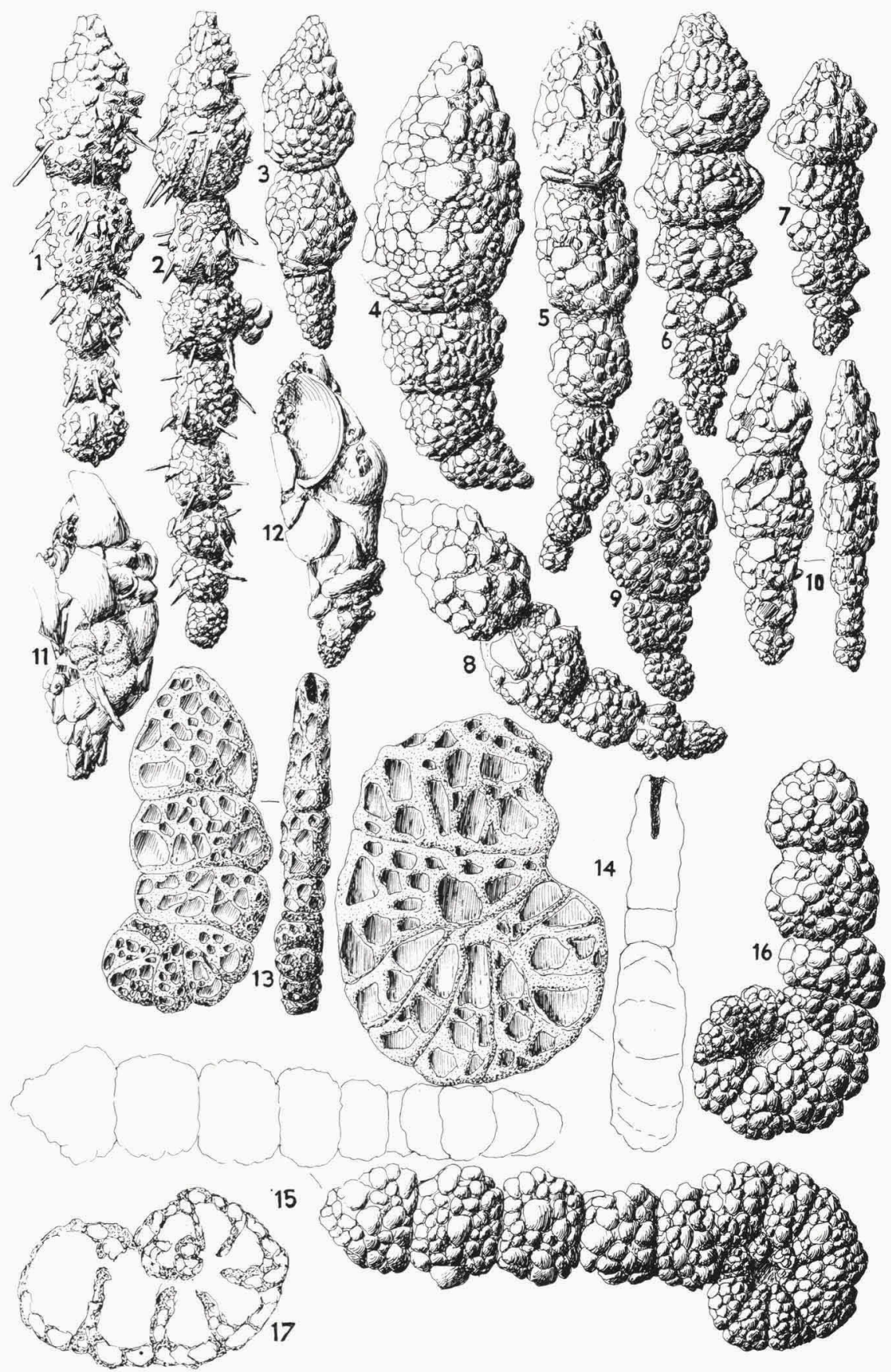

Figs. 1-2. Reophax hispidulus Cushman, St. 36, $400 \mathrm{~m}, \times 66$. Figs. 3-4. R. curtus Cushman, St. $113,254 \mathrm{~m}, \times 33$. Figs. 5. 8. $R$. regularis Höglund, St. $22,240 \mathrm{~m}, \times 66$. Figs. $6-7 . R$. guttifer Brady. St. $87,33.5 \mathrm{~m}, \times$ 66. Fig. 9. $R$. biiocularis Flint, St. $36,400 \mathrm{~m}, \times 33$. Fig. $10 . R$. compressus Goës. St. 34, $85 \mathrm{~m}, \times 33$. Figs. $11-12 . R$. petrosus Mikhalewich, St. $88,46 \mathrm{~m}, \times 33$. Figs. 13,14 , 17. Ammobaculites americanus Cushman; 13. St. $61,35 \mathrm{~m}, \times 66 ; 14, \mathrm{St} .102,81 \mathrm{~m}, \times 66 ; 17$, St. $30,41 \mathrm{~m}$, horizontal section, $\times$ 66. Figs. 15-16. A. agglutinans (d'Orbigny); 15, St. $36,400 \mathrm{~m}, \times$ $66 ; 16$, St. $13,940 \mathrm{~m}, \times 66$. 

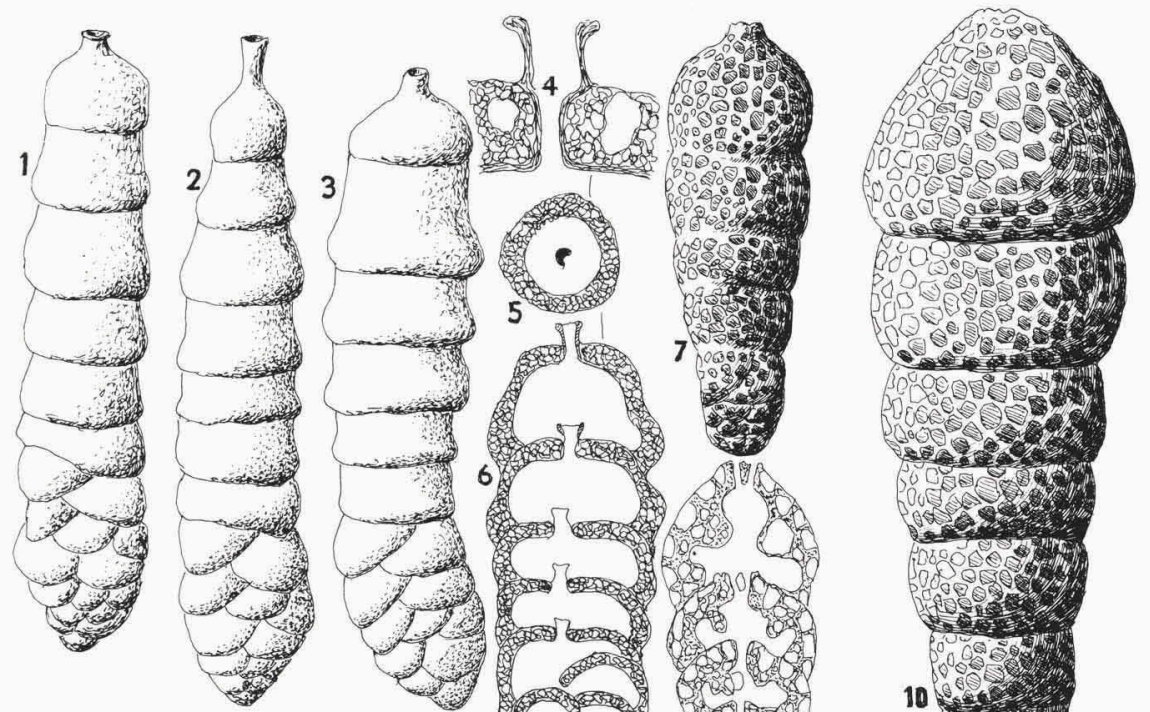

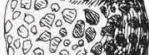
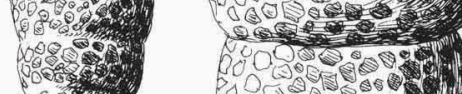

5 atsons

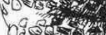

0

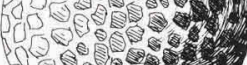

k 3 .

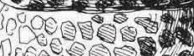

Uovis 20

\% $10 \%$

30 ,

pors.

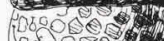

0009809

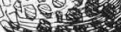

sitis

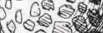

10

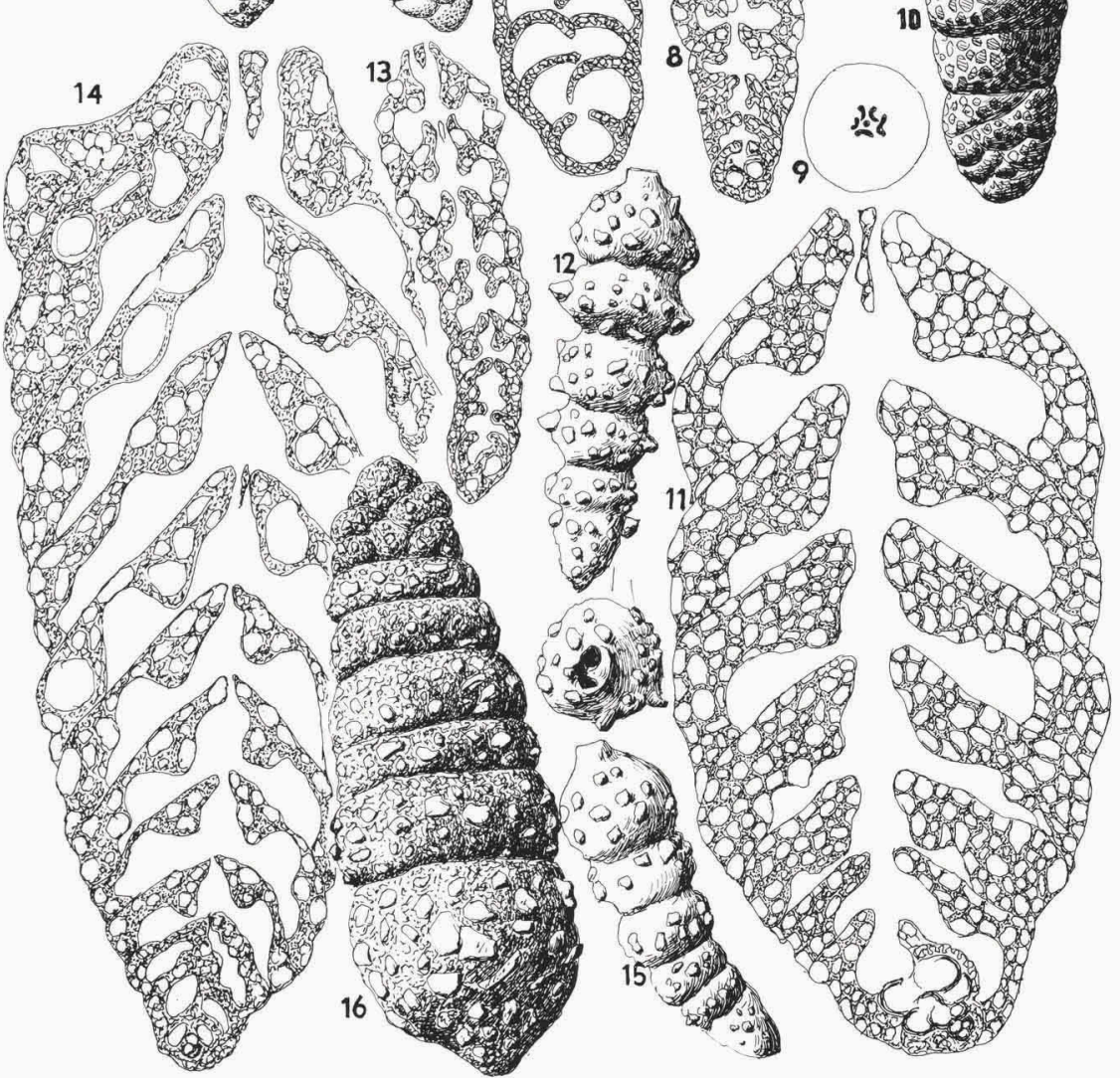

Figs. 1-6. Martinottiella pallida (Cushman); 1-3, St. 36, $400 \mathrm{~m}, \times 66 ; 4$, longitudinal section through aperture, $\times 200 ; 5-6$, transverse and longitudinal sections, $\times 66$. Figs. 7-11. Liebusella arenosa nov. spec.; 7-9, St. 104, $55 \mathrm{~m}, \times 33$; megalospheric $(8$, longitudinal section; 9 , apertural view); 10, microspheric, St. 114B. $138 \mathrm{~m}, \times 17 ; 11$, longitudinal section, St. 102G, $90 \mathrm{~m}, \times 66$. Figs. 12-16. L. eleganta nov. spec.; 12, megalospheric specimen, apertural view, St. $102 \mathrm{G}, 81 \mathrm{~m}$, $\times 33 ; 15$, another specimen, same locality, $\times 33 ; 13$, longitudinal section, $\times 33 ; 14,16$, microspheric generation, St. 102G, $90 \mathrm{~m} ; 14$, longitudinal section, $\times 33 ; 16$, whole specimen. 


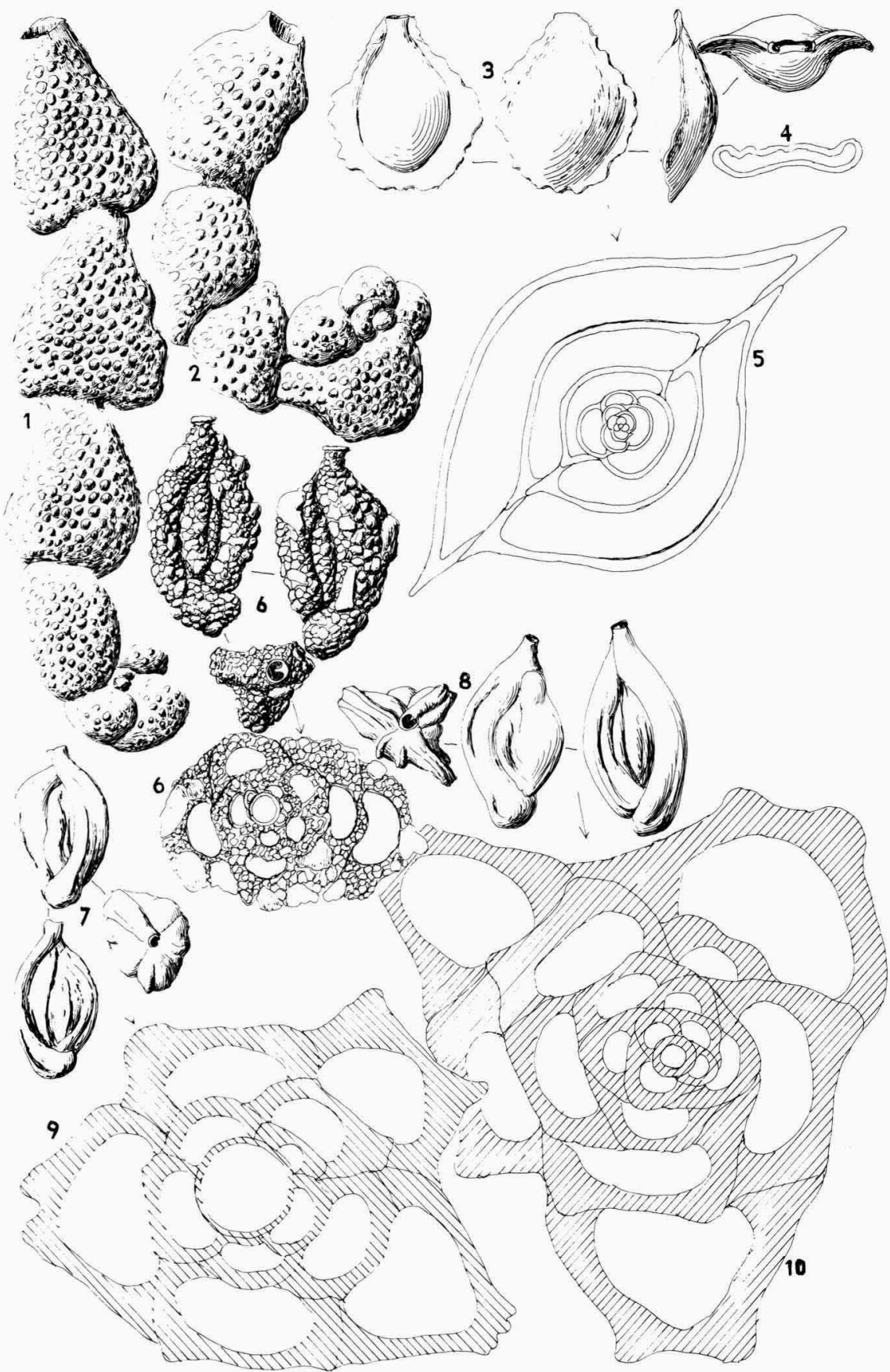

Figs. 1-2. Nodobacularia pustulosa nov. spec.; 1. St. 31G, $84 \mathrm{~m} ; 2$, St. $118,48,5 \mathrm{~m}$; both $\times 66$. Figs. 3-5. Pyrgoides nasutus Cushman; 3-4, St. 24, $66 \mathrm{~m}, \times 33 ; 5$, transverse section through microspheric specimen, St. $82.51 \mathrm{~m}, \times$ 66. Fig. 6. Quinqueloculina horrida Cushman, St. 37,121 $\mathrm{m}$; from three sides, $\times 33$, and transverse section, $\times 66$. Figs. 7-10. $Q$. polygona d'Orbigny, St. 86, $42 \mathrm{~m} ; 7$, megalospheric specimen from three sides, $\times 66 ; 8$, microspheric specimen grom three sides, $\times 66 ; 9$, transverse section through specimen of $7, \times 200 ; 10$, transverse section through specimen of $8, \times 200$. 


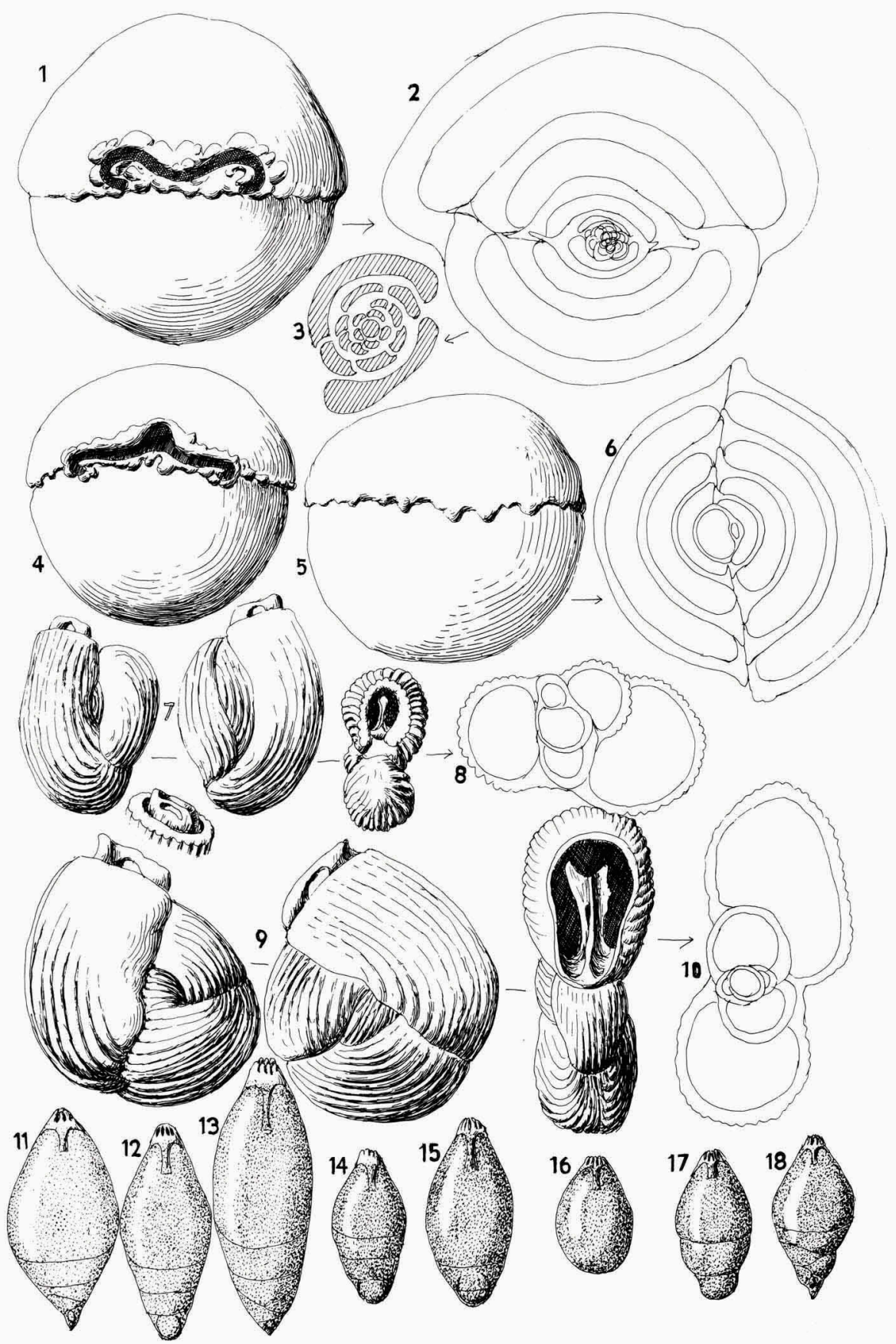

Figs. 1-6. Sigmopyrgo vespertilio (Schlumberger); 1-3, microspheric, St. 97, $130 \mathrm{~m} ; 1$, apertural face, $\times 33 ; 2$, transverse section, $\times 42 ; 3$, central part of section, $\times 66 ; 4-6$, megalospheric, St. $98,85 \mathrm{~m}$, from two sides $(4,5)$ and section through it $(6), \times 33$. Figs. $7-10$. Flintina bradyana Cushman; 7-8, small specimen not showing the triserial chambers, from three sides and tooth in aperture, St. $90,45 \mathrm{~m}, \times 33$, transverse section $\times 50 ; 9-10$, large specimen, in the end triserial, St. $91,37,5 \mathrm{~m}$, from three sides $\times 33$, section $\times 50$. Figs. 11-18. Glandulina surinamensis nov. spec., all tests $\times 66 ; 11-13$, St. $31,38 \mathrm{~m}$, two microspheric, one megalospheric; 14 , St. 35, $35 \mathrm{~m}$, megalospheric; $15-17$, St. 3, $36 \mathrm{~m}$ (16 with very large proloculus, which forms whole test); 18, St. 


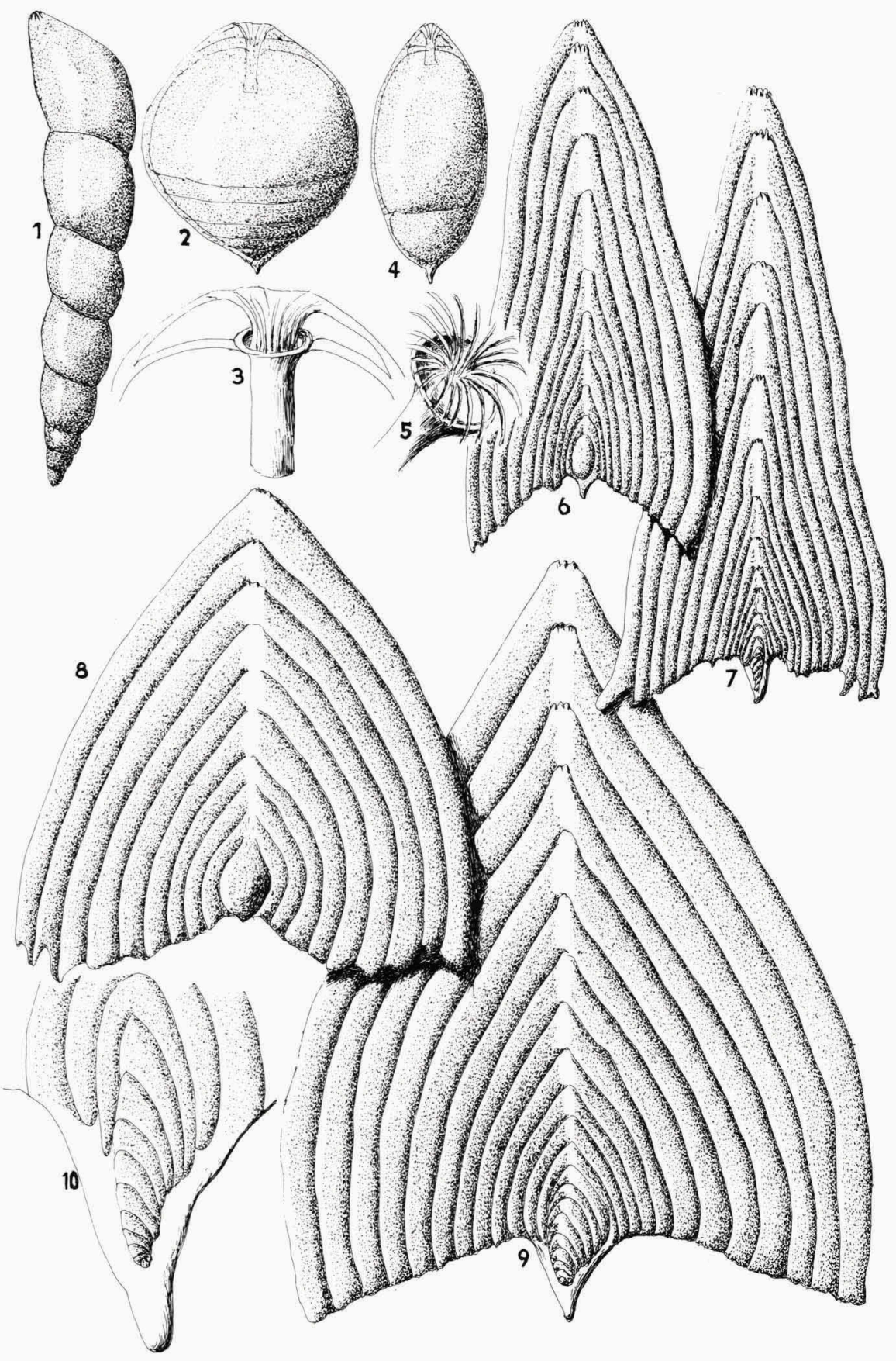

Fig. 1. Dentalina bradyensis (Dervieux), St. 114B, $138 \mathrm{~m}, \times 33$. Figs. 2-5. Glandulina torrida Cushman, St. 13, $940 \mathrm{~m} ; 2$, microspheric; 3.5 . apertural structure seen through the test wall; 4 , megalospheric $(2,4, \times 33 ; 3,5, \times 66)$. Figs. 6 9. Frondicularia sagittula $\mathrm{Van}$ den Broeck; 6-7, megalospheric and microspheric, St. $2 \mathrm{G}, 93 \mathrm{~m}, \times 11 ; 8$, megalospheric, St. 3G, $80 \mathrm{~m}, \times 11 ; 9$. microspheric, St. $56 \mathrm{G}, 86 \mathrm{~m}, \times 11 ; 10$, initial part of microspheric specimen of $9, \times 66$. 


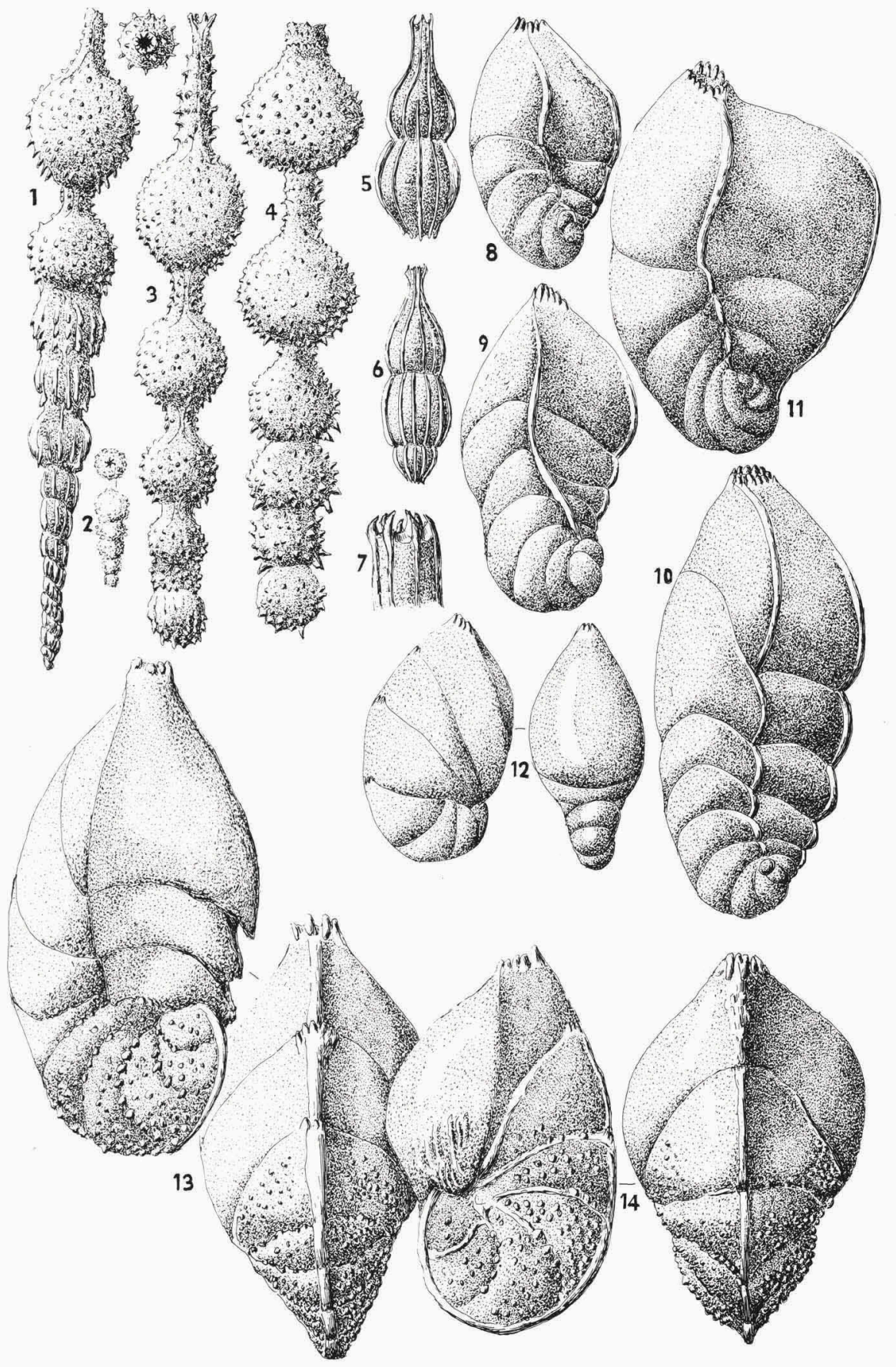

Figs. 1-4. Amphicoryna rugosa d'Orbigny; 1, microspheric, St. $22,240 \mathrm{~m} ; 2$, with broken aperture showing the star-like inner structure; 3, megalospheric, St. 96, $207 \mathrm{~m} ; 4$, St. 113, $254 \mathrm{~m}$, showing 5 initial chambers without necks, identical with the chambers figured by d'Orbiny and refigured in fig. 2. All figures of specimens from the shelf, $\times 66$. Figs. 5-7. A. catesbyi (d'Orbigny); 5, St. 31, $38 \mathrm{~m}, \times 66 ; 6$, St. 86, $42 \mathrm{~m} ; 7$, aperture with the characteristic dents, $\times 200$. Figs. $8-10$. Saracenaria eleganta nov. spec., St. $112,88.5 \mathrm{~m}, \times 33$. Fig. 11. S. ampla Cushman \& Todd, St. 60G, 95 $\mathrm{m}, \times$ 33. Fig. 12. $S$. arcuata d'Orbigny, from two sides, St. $22,240 \mathrm{~m}, \times 66$. Figs. $13-14 . S$. palmerae Cushman \& Todd; 13, St. 114B, $138 \mathrm{~m}, \times 66$; 14, St. 112, 88,2 m, $\times 66$. 


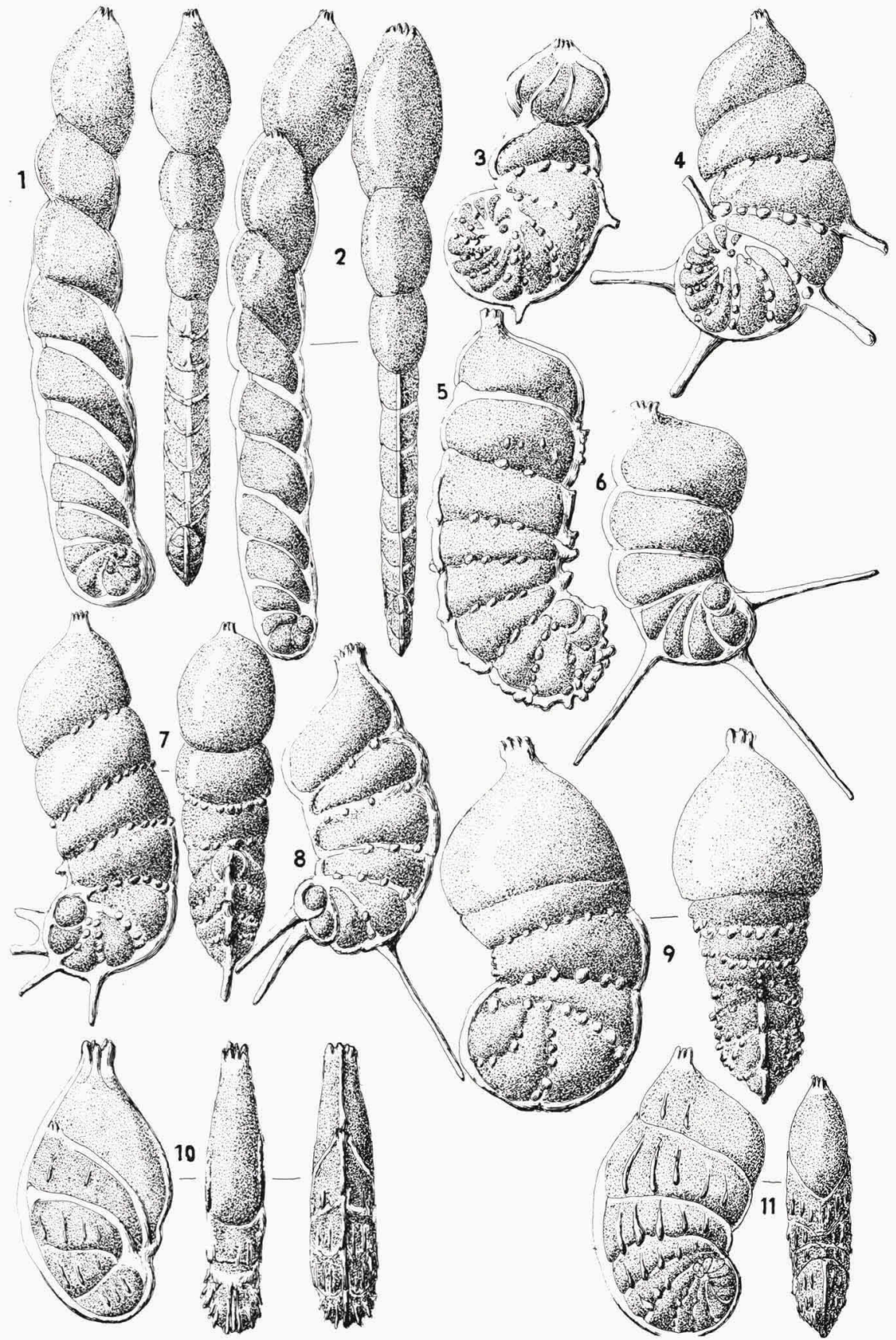

Figs. 1-2. Marginulina tenuis Bornemann, microspheric and megalospheric specimen, both from two sides. St. 22, $240 \mathrm{~m}, \times$ 66. Figs. 3-8. M. glabrata (Cushman); 3, microspheric with abnormal end-chamber as also figured by Goës (1882), St. 113, $254 \mathrm{~m}, \times 33 ; 4$, microspheric, normal endchamber, same dates; 5 . large megalospheric, same dates; 6 , megalospheric, same date; 7 , megalospheric, from two sides, St. 96, $207 \mathrm{~m}, \times 33 ; 8$, megalospheric, same dates. Fig. 9. M. subarcuata (Cushman), from two sides, St. 101, $120 \mathrm{~m}, \times 66$. Fig. 10. M. anderseni nov. spec., from three sides, St. 20, $46.5 \mathrm{~m}, \times$ 33. Fig. 11. M. planata Phleger \& Parker, microspheric, from two sides, St. 


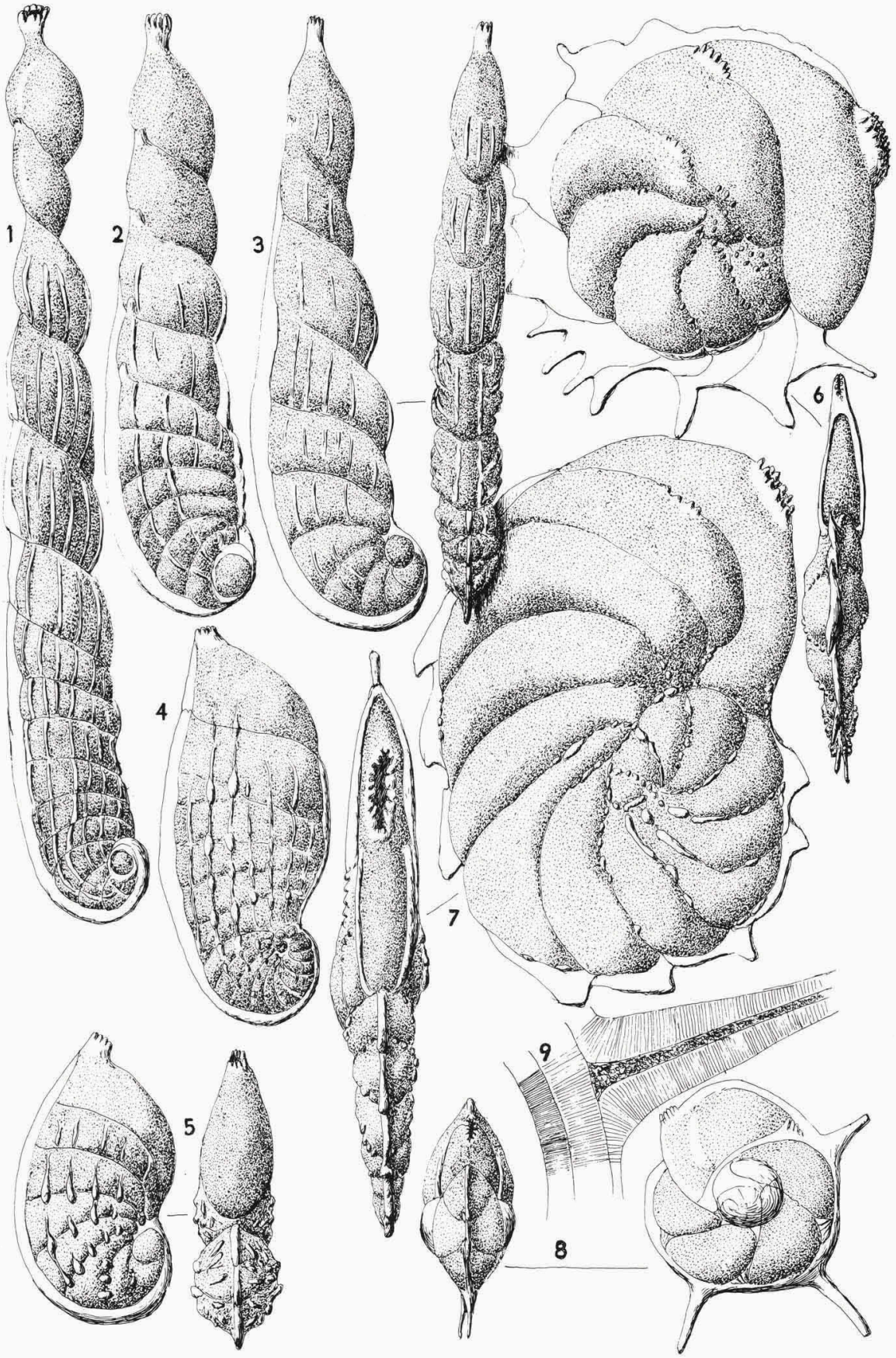

Figs. 1-5. Marginulina planata Phleger \& Parker; 1, strongly developed megalospheric specimen, St. $73,55 \mathrm{~m}, \times 33 ; 2$, with large proloculus, St. $115,83 \mathrm{~m}, \times 33 ; 3$, megalospheric, from two sides, St. $102,81 \mathrm{~m}, \times 33 ; 4$, microspheric, St. 73, $55 \mathrm{~m}, \times 33 ; 5$, small megalospheric, from two sides, St. 102, $81 \mathrm{~m}, \times$ 33. Figs. 6-7. Lenticulina antillea (Cushman); 6, megalospheric, St. 82G, $88 \mathrm{~m}, \times 15 ; 7$, L. antillea (Cushman), possibly microspheric, from two sides, St. $2 \mathrm{G}, 93 \mathrm{~m}, \times 15$. Figs. 8-9. L. calcar (Linnaeus); 8, specimen from two sides, St. 113, $254 \mathrm{~m}, \times 33 ; 9$, part of section showing wall and spine, $\times 200$. 


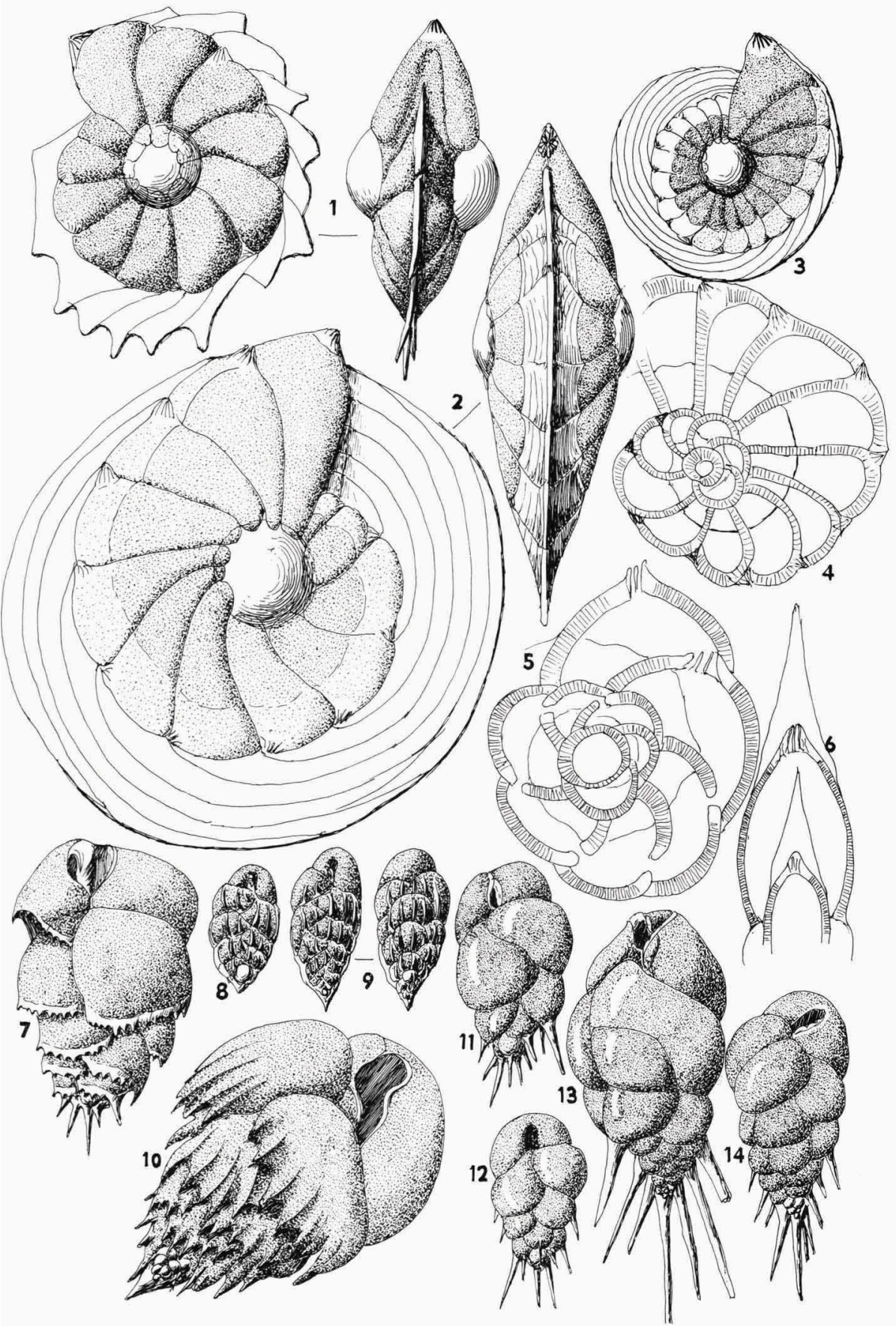

Fig. 1. Lenticulina formosa (Cushman), from two sides, St. $36,400 \mathrm{~m}, \times 33$. Figs. $2-6$. L. iota (Cushman): 2, megalospheric. from two sides, St. 113, $254 \mathrm{~m}, \times 33 ; 3$, microspheric, St. 48G, 500 $\mathrm{m}, \times 10 ; 4$, centre of horizontal section of $3, \times 66 ; 5$, centre of horizontal section, with large proloculus, of $2, \times 66 ; 6$, part of transverse section, showing the thick bases of the carinae, of 3 , $\times$ 33. Fig. 7. Bulimina marginata d'Orbigny, St. $96,207 \mathrm{~m}, \times 66$. Figs. 8-9. B. alazanensis Cushman, St. 13, $940 \mathrm{~m}, \times 66$; megalospheric and microspheric from two sides. Fig. 10. B. spicata Phleger \& Parker, microspheric, St. 36, $400 \mathrm{~m}, \times 66$. Figs. 11-14. B. aculeata d'Orbigny; 11, 13 , St. $36,400 \mathrm{~m} ; 12$, 14, St. $13,940 \mathrm{~m}$; from each locality a megalospheric and a microspheric individual are figured; $\times 66$. 


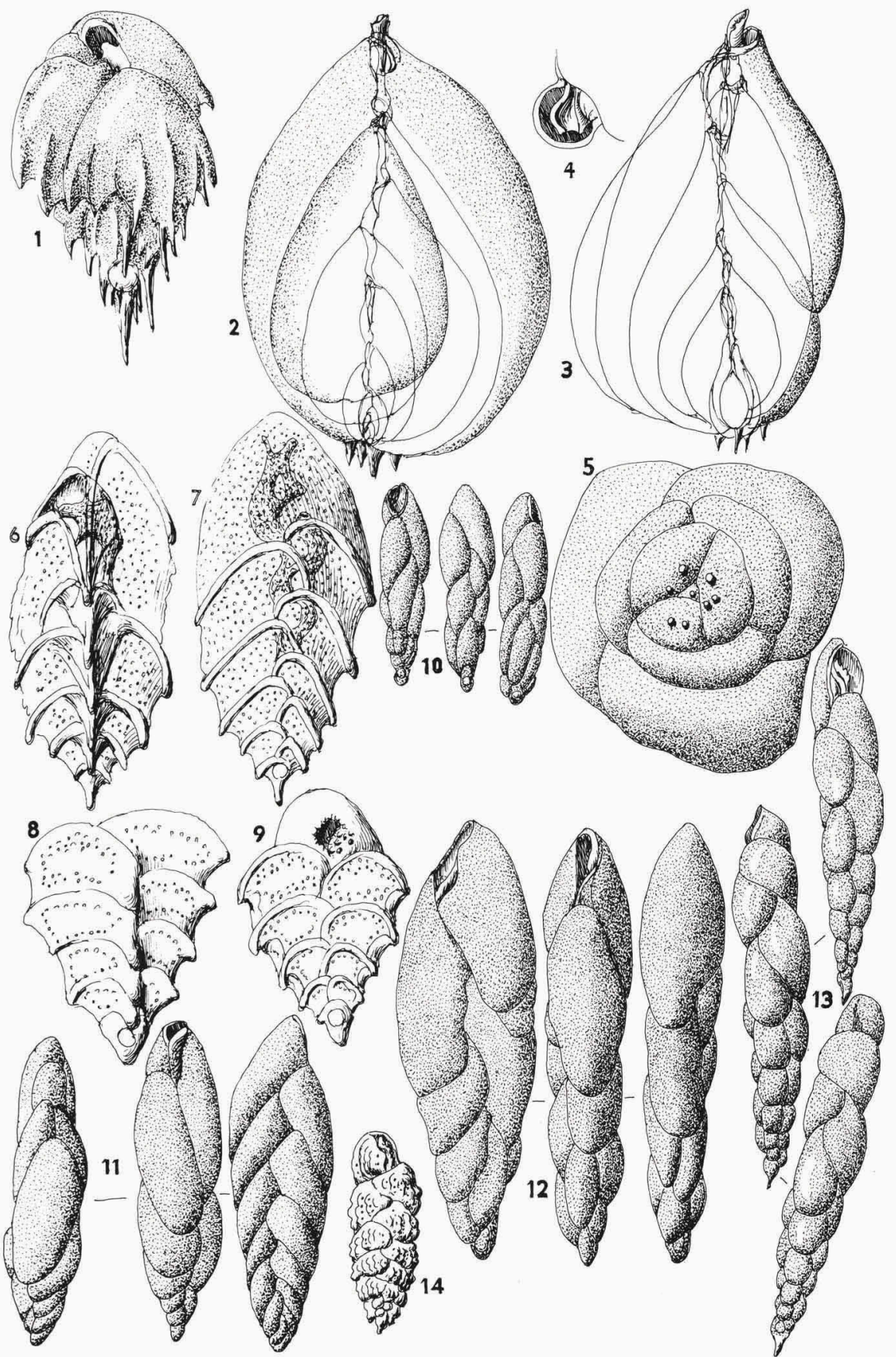

Fig. 1. Bulimina spicata Phleger \& Parker, megalospheric, St. 36, $400 \mathrm{~m}, \times$ 66. Figs. 2-5. Protoglobobulimina turgida (Bailey), St. 22, $240 \mathrm{~m} ; 2$, microspheric, $\times 66 ; 3$, megalospheric, $\times 66 ; 4$, mouth with toothplate, $\times 80 ; 5$, initial view showing the triserial structure, $\times 66$. Fgis. 6-7. Reussella atlantica Cushman. St 58, $66 \mathrm{~m}$, from two sides, $\times 66$. Figs. 8-9. R. mortenseni Hofker, St. $114 Z, 132 \mathrm{~m}$, from two sides, $\times$ 66. Fig. 10. Virgulina pontoni Cushman, St. $61,36 \mathrm{~m}, \times 66$. Fig. 11. V. mexicana Cushman, St. 13, $940 \mathrm{~m}$, from three sides, $\times 66$. Fig. 12. V. compressa (Bailey), St. 36, $400 \mathrm{~m}$, from three sides, $\times$ 66. Fig. 13. Stainforthia exilis (Brady), St. 13, $940 \mathrm{~m}$, from three sides, $\times 66$. Fig. 15. Virgulinopsis cubana (Bermúdez), St. 86, $42 \mathrm{~m}, \times 66$. 


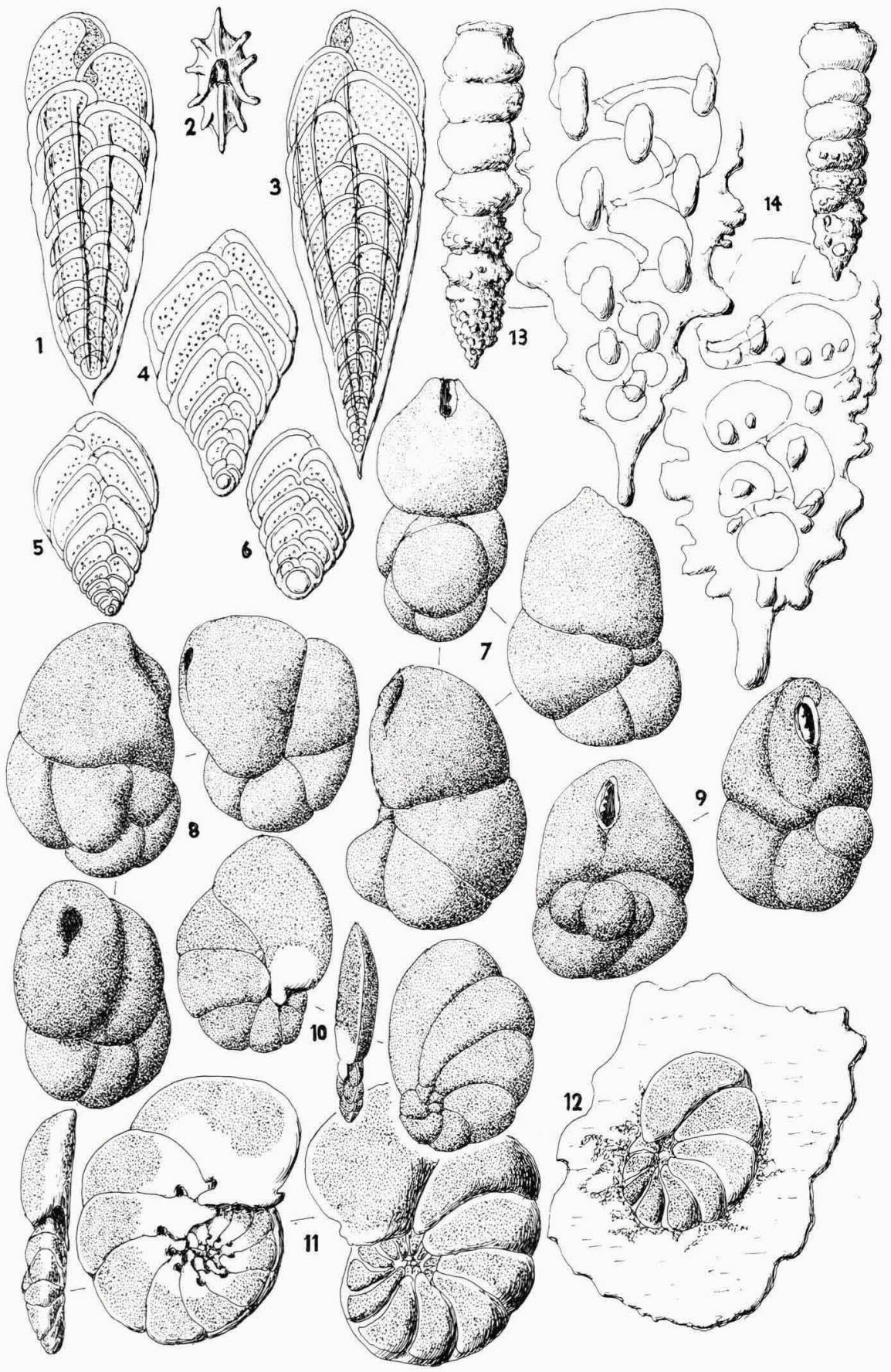

Figs. 1-3. Bolivina mexicana Cushman, St. 113, $254 \mathrm{~m}, \times 66 ; 1$, megalospheric; 2, apertural face: 3. microspheric. Figs. 4-6. B. goesi (Cushman). St. 101, $120 \mathrm{~m}, \times 66 ; 4$, 6, megalospheric; 5 . microspheric. Figs. 7-9. Globocassidulina aperta nov. spec.; 7, St. $98,85 \mathrm{~m}$, from three sides, $\times$ 33; 8 , St. $98,85 \mathrm{~m}$, from three sides, $\times 33 ; 9$, St. $2 \mathrm{G}, 93 \mathrm{~m}$, from two sides, $\times 33$. Fig. 10. Cancris sagrai (d'Orbigny), St. 3, $36 \mathrm{~m}$, from three sides, $\times$ 66. Figs. 11-12. Hanzawaia concentrica (Cushman); 11, St. 31, $38 \mathrm{~m}$, microspheric, from three sides, $\times 66 ; 12$, St. $111,51.5 \mathrm{~m}$, megalospheric, attached to shell, with calcareous particles attached, $\times 66$. Figs. 13-14. Rectobolivina advena (Cushman), St. 86, $42 \mathrm{~m} ; 13$, microspheric, $\times 66$, with initial part $\times 200 ; 14$, megalospheric, $\times 66$, with enlarged initial part $\times 200$. 


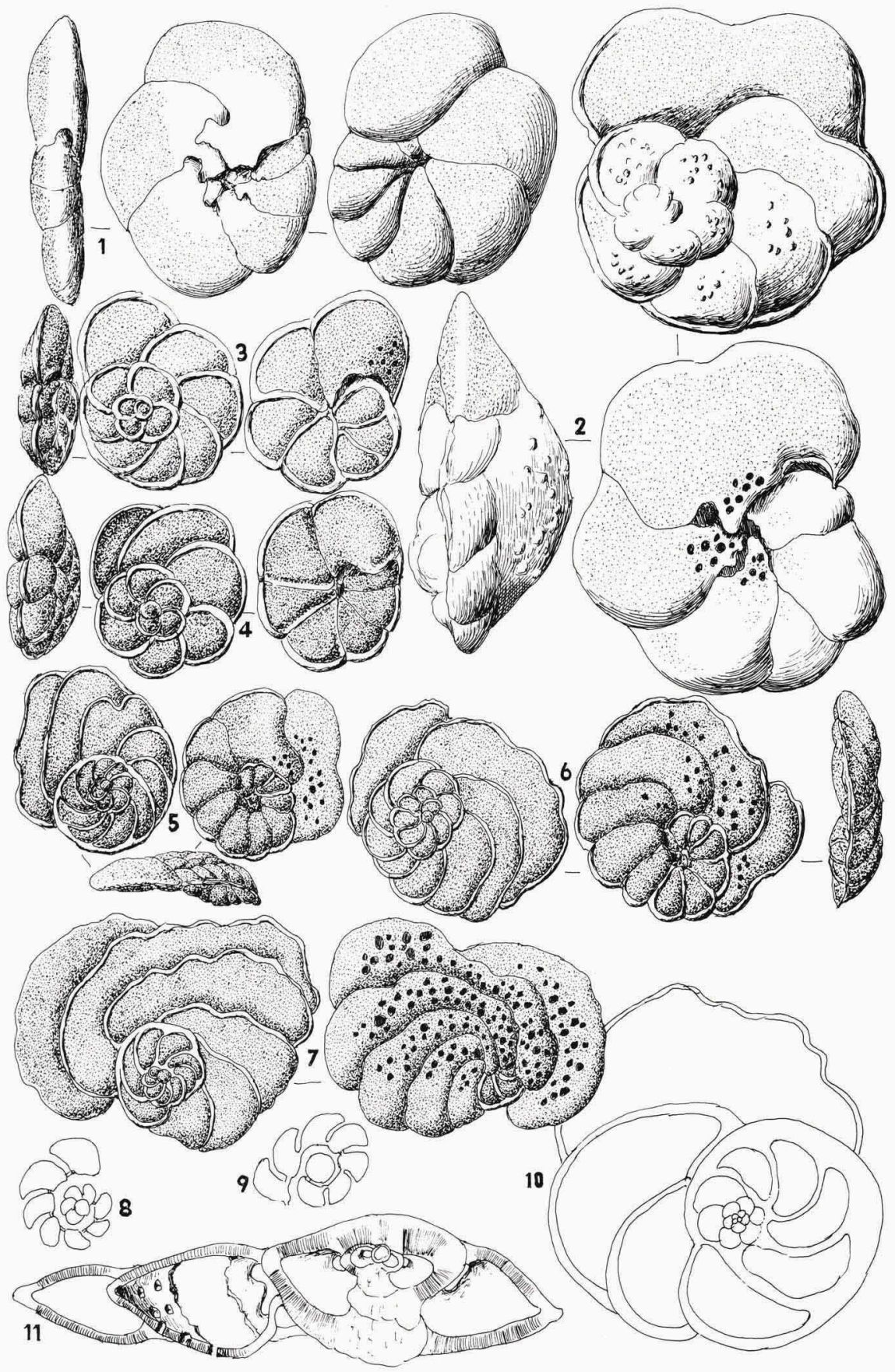

Fig. 1. Hanzawaia concentrica (Cushman), St. $24,66 \mathrm{~m}$, megalospheric, from three sides, $\times 66$. Figs. 2-4. Eponides repandus (Fichtel \& Moll); 2, microspheric, known as Sestronophora, Mar Alboran, Mediterranean, St. Colom 365-541, $98 \mathrm{~m}, \times 33 ; 3$, megalospheric, known as Poroeponides, St. 117, $54 \mathrm{~m}$, from three sides, $\times 33 ; 4$, megalospheric, from three sides, Secca Palumno, Bay of Naples, $100 \mathrm{~m}, \times$ 33. Figs. 5-11. E. lateralis (Terquem); 5, living specimen just caught, from three sides, St. $81,8 \mathrm{~m}, \times 33 ; 6$, another specimen from three sides, same locality; 7, St. 73, $55 \mathrm{~m}$, very large specimen from two sides, $\times 100 ; 8-9$, megalospheric, central initial chambers coiling to the left and to the right, $\times 66 ; 10$, St. $34,85 \mathrm{~m}$, microspheric, large, coiling to the right, $\times 66 ; 11$, St. $81,8 \mathrm{~m}$, megalospheric, transverse section, $\times 33$. 


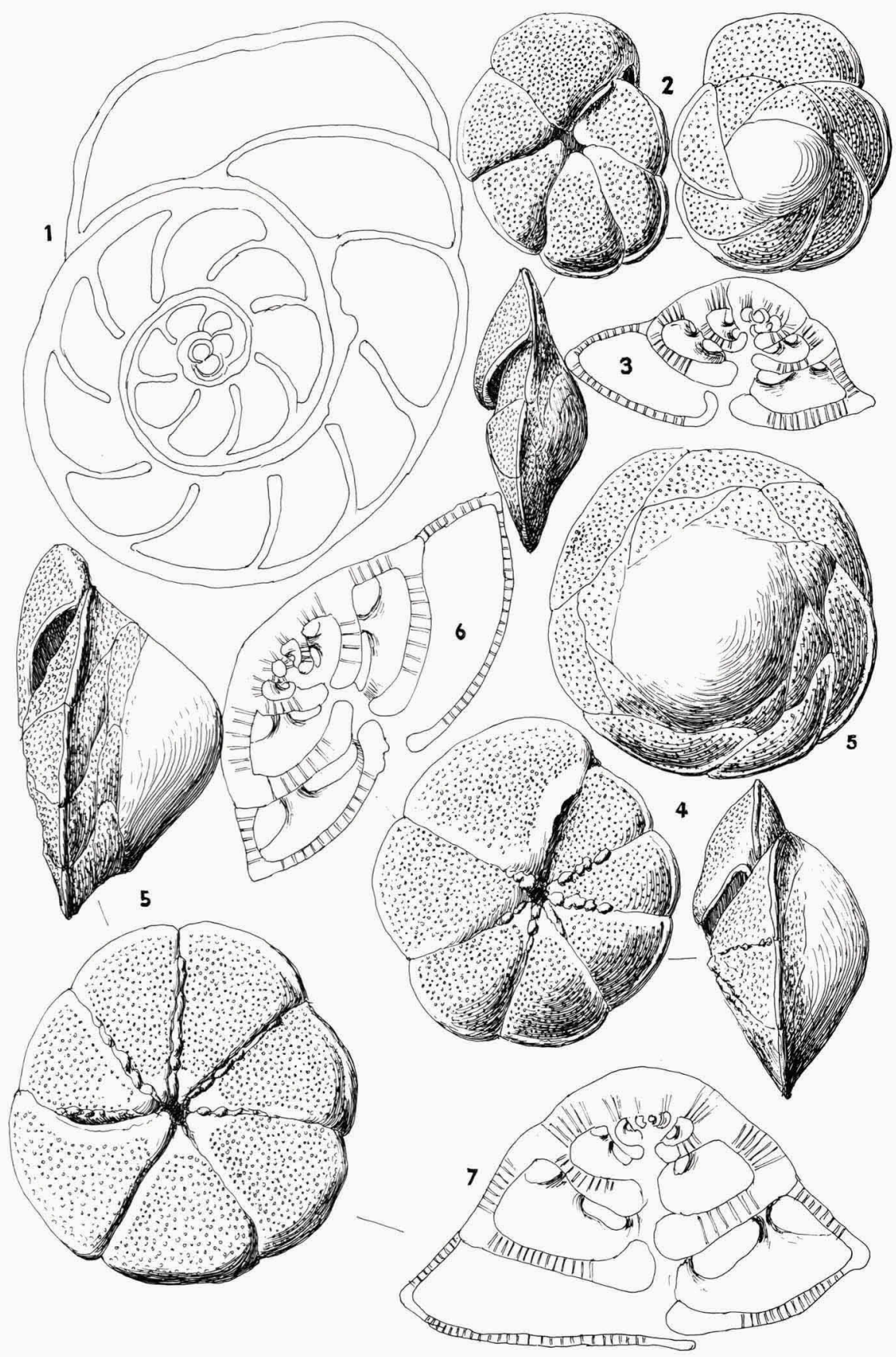

Fig. 1. Eponides lateralis (Terquem), St. $81,8 \mathrm{~m}$, megalospheric, seen in clarifyer, $\times 66$. Figs. $2-7$. E. antillarum (d'Orbigny); 2-3. St. $20,46.5 \mathrm{~m}$, megalospheric, from relatively shallow water, showing the ventral smooth sutures, from three sides, with transverse section and megalospheric proloculus, $\times 66 ; 4,6$, St. 73, $55 \mathrm{~m}$, megalospheric, from slightly deeper water and with thickened sutures and transverse section lenticular, $X 66$ and $\times 75$, respectively; 5, 7, St. 23, 95 m, microspheric, the only form found in deeper water, with dome-like dorsal side and strongly thickened ventral sutures, and with transverse section, $\times 66$ and $\times 75$, respectively. 


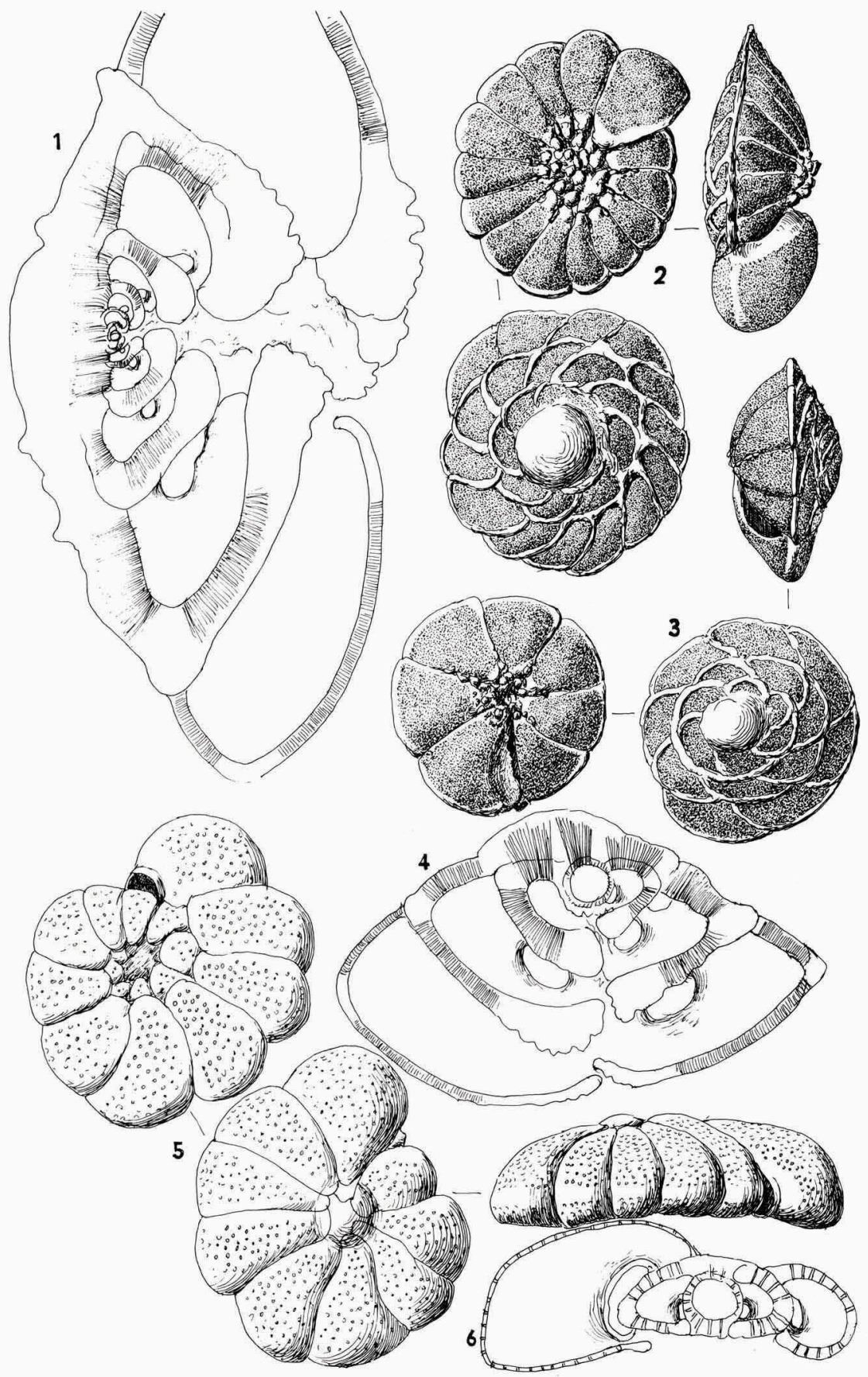

Figs. 1-4. Eponides campester Palmer \& Bermúdez, St. 22, $240 \mathrm{~m} ; 1$, microspheric, transverse section, $\times 100 ; 2$, microspheric, from three sides, $\times 33 ; 3$, megalospheric, from three sides, $\times 33$; 4. megalospheric, transverse section, $\times$ 66. Figs. 5-6. Cibicides antilleanus Drooger, St. $36,400 \mathrm{~m}$, from three sides and transverse section, $\times 66$. 


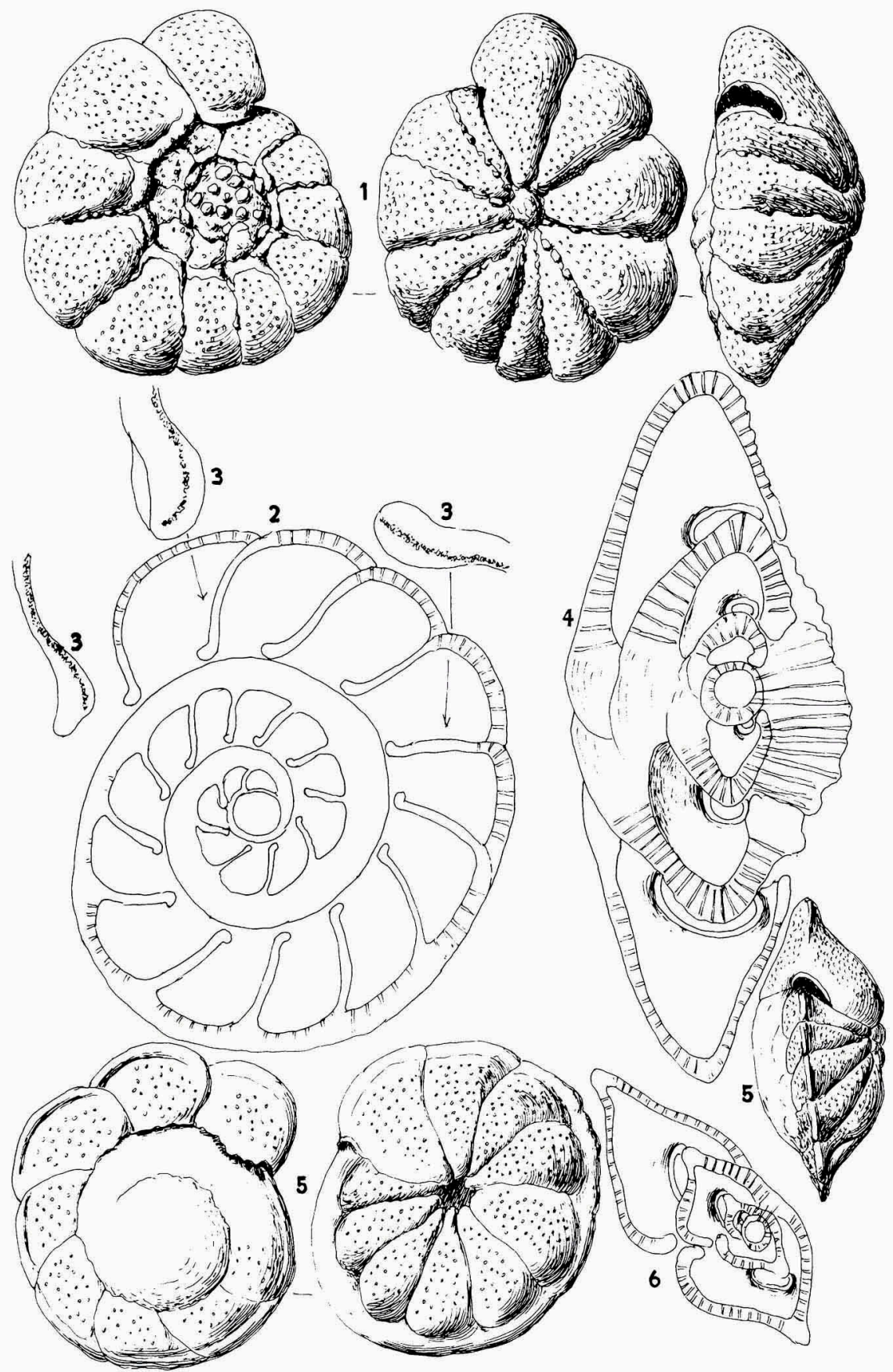

Figs. 1-4. Cibicides robustus Phleger \& Parker, St. 114A, $132 \mathrm{~m} ; 1$, from three sides, $\times 66 ; 2$. horizontal section, $\times 125: 3$, apertural ends of septa. $\times 400 ; 4$, transverse section, $\times 125$. Figs. 5-6. C. pseudoungerianus Cushman, St. $113.254 \mathrm{~m}$, from three sides and transverse section, $\times 66$. 


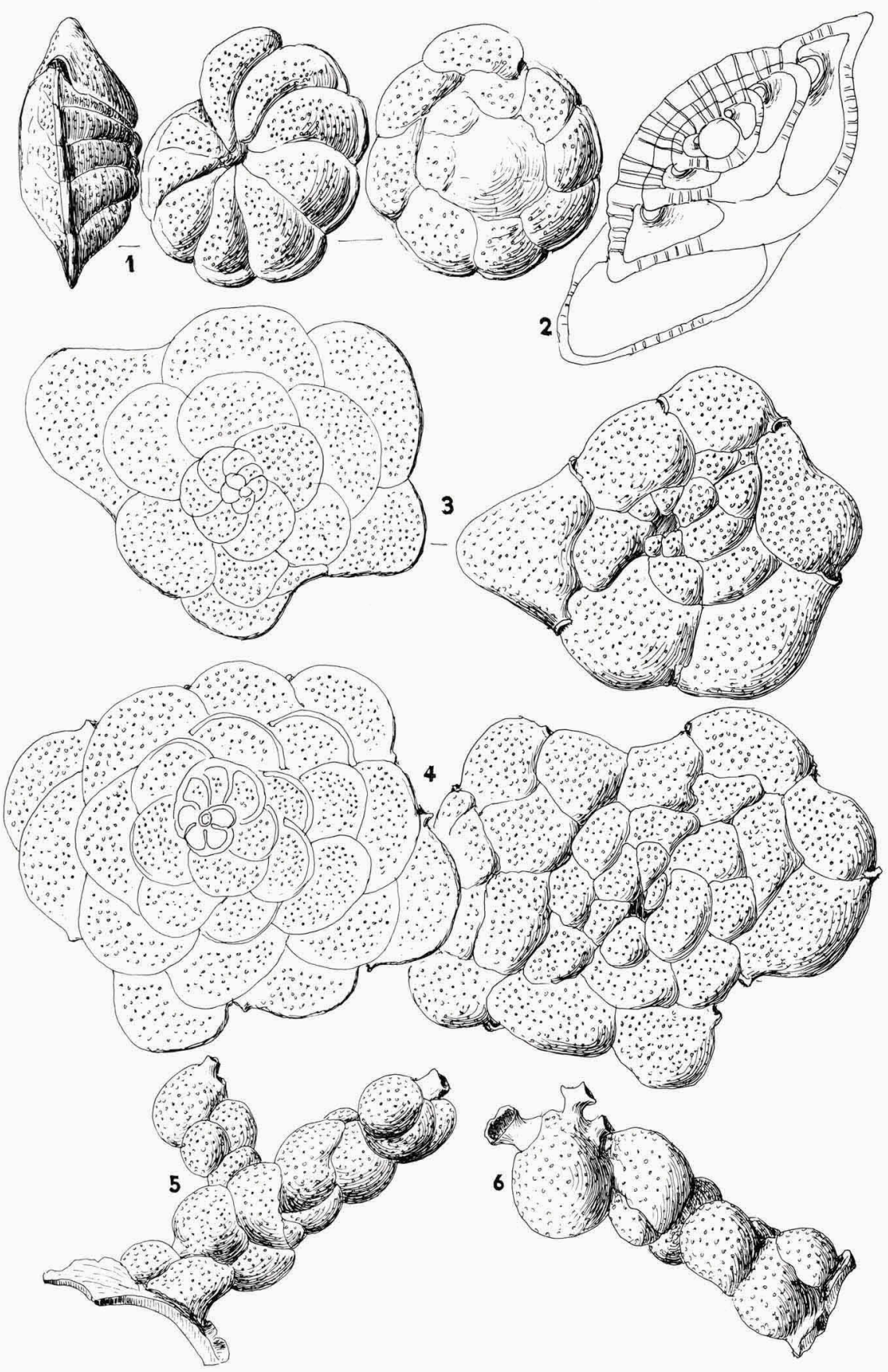

Figs. 1-2. Cibicides mollis Phleger \& Parker, St. 113, $254 \mathrm{~m} ; 1$, test from three sides, $\times 66 ; 2$, transverse section, $\times 100$. Figs. 3-4. Planorbulina caribbeana Hofker; 3, St. 3, $38 \mathrm{~m}, \times 66 ; 4$, St. $97.130 \mathrm{~m}, \times 66$; both from dorsal and ventral sides. Figs. 5-6. Biarritzina proteiformis (Goës); 5 , St. $102 \mathrm{G}, 90 \mathrm{~m}, \times 12: 6$, St. $57 \mathrm{G}, 90 \mathrm{~m}, \times 12$. 


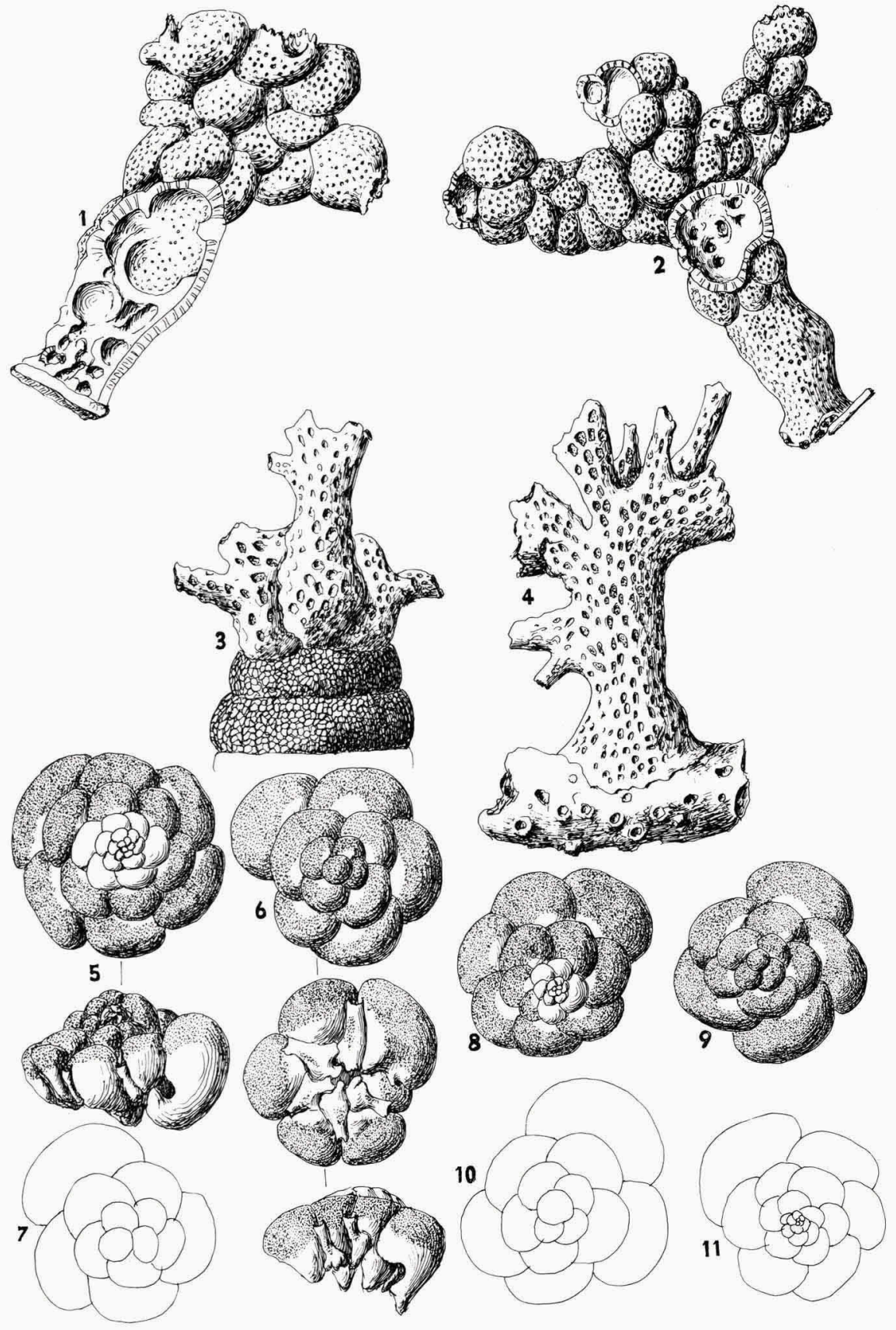

Figs. 1-2. Sporadotrema mesentericum (Carter): 1, St. 84G, $70.5 \mathrm{~m}, \times 7 ; 2$, St. $56 \mathrm{G}, 86 \mathrm{~m}, \times 7$. Figs. 3-4. Homotrema rubrum (Lamarck); 3, St. 51 G, 98 m. on Textulariella. $\times 12$; 4. St. 52 G. 96 $\mathrm{m}$. on a piece of fossil coral. $\times 12$. Figs. $5-11$. Asterorotalia rolshauseni (Cushman \& Bermúdez), $\times$ 66: 5. St. $61.35 \mathrm{~m}$. microspheric, from two sides: 6 , megalospheric, from three sides; 7 , St. 30 , $41 \mathrm{~m}$, megalospheric; 8, same locality, microspheric; 9, same locality, megalospheric; 10, St. 66, $35 \mathrm{~m}$, megalospheric; 11 , same locality, microspheric. 